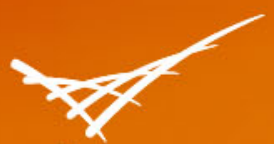 \\ Pacific Northwest \\ NATIONAL LABORATORY
}

Proudly Operated by Battelle Since 1965

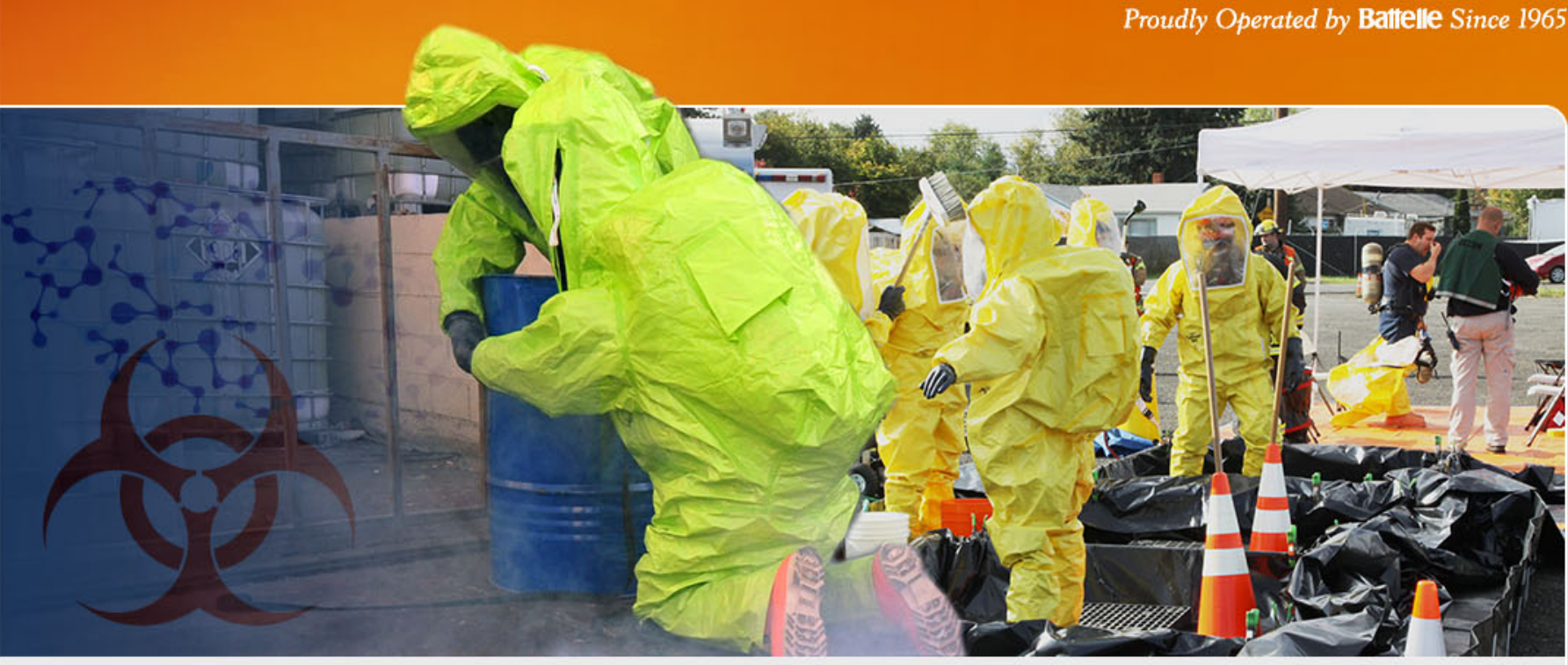

\section{Biodetection Technologies for First Responders: 2014 Edition}

\author{
RM Ozanich HA Colburn \\ CL Baird TM Straub \\ RA Bartholomew CJ Bruckner-Lea
}

\section{March 2014}

http://biodetectionresource.pnnl.gov

U.S. DEPARTMENT OF
Security


This guide was prepared for the Department

of Homeland Security Science and

Technology Directorate under Contract

HSHQDC-08-X-00843.

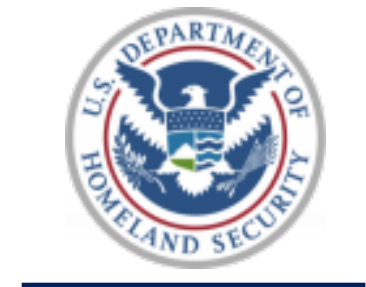

Science and Technology

DISCLAIMER

This report was prepared as an account of work sponsored by an agency of the United States Government. Neither the United States Government nor any agency thereof, nor Battelle Memorial Institute, nor any of their employees, makes any warranty, express or implied, or assumes any legal liability or responsibility for the accuracy, completeness, or usefulness of any information, apparatus, product, or process disclosed, or represents that its use would not infringe privately owned rights. Reference herein to any specific commercial product, process, or service by trade name, trademark, manufacturer, or otherwise does not necessarily constitute or imply its endorsement, recommendation, or favoring by the United States Government or any agency thereof, or Battelle Memorial Institute. The views and opinions of authors expressed herein do not necessarily state or reflect those of the United States Government or any agency thereof.

\author{
PACIFIC NORTHWEST NATIONAL LABORATORY \\ operated by \\ BATTELLE \\ for the \\ UNITED STATES DEPARTMENT OF ENERGY \\ under Contract DE-AC05-76RL01830
}

Printed in the United States of America

$$
\begin{aligned}
& \text { Available to DOE and DOE contractors from the } \\
& \text { Office of Scientific and Technical Information, } \\
& \text { P.O. Box 62, Oak Ridge, TN } 37831-0062 ; \\
& \text { ph: (865) 576-8401 } \\
& \text { fax: (865) 576-5728 } \\
& \text { email: reports@adonis.osti.gov }
\end{aligned}
$$

\author{
Available to the public from the National Technical Information Service, \\ U.S. Department of Commerce, 5285 Port Royal Rd., Springfield, VA 22161 \\ ph: (800) 553-6847 \\ fax: (703) 605-6900 \\ email: orders@ntis.fedworld.gov \\ online ordering: http://www.ntis.gov/ordering.htm
}


PNNL-23036

\title{
Biodetection Technologies for First Responders: 2014 Edition
}

\author{
RM Ozanich \\ HA Colburn \\ CL Baird \\ TM Straub \\ RA Bartholomew \\ CJ Bruckner-Lea
}

March 2014

Prepared for the Department

of Homeland Security Science and

Technology Directorate under Contract

HSHQDC-08-X-00843.

Pacific Northwest National Laboratory

Richland, Washington 99352

Available for download @ http://biodetectionresource.pnnl.gov 



\section{Summary}

Responding to a potential biological incident requires a number of competencies, including analyzing the incident, identifying methods of dissemination, identifying biological threat agents, planning the response, implementing the planned response, evaluating progress, and terminating the incident. The National Fire Protection Association $\left(\mathrm{NFPA}^{\circledR}\right)$ outlines the minimum required competencies in NFPA $^{\circledR}$ 472. ${ }^{1}$ Detailed standardized response protocols are given in ASTM E2770-10. ${ }^{2}$

When investigating a suspicious powder incident, a wide variety of sample collection products, fielddeployable assays and detection systems can be used to determine if the substance contains biological material and warrants further investigation. First responders have several significant factors to consider before purchasing biological sampling and detection technologies, including the following:

- type of information obtained, usefulness and accuracy of results (performance)

- ease-of-use in the field

- total cost of ownership (e.g., hardware, consumables, and training needs), understanding that reagent cost, shelf-life, instrument maintenance, and upgrades are significant contributors

- total time from sample to answer

- weight and size.

This guide summarizes commercially available technologies that can be used by first responders in the field for the collection, screening and identification of biological materials. This is not meant to be an exhaustive list, nor an endorsement of any technology described herein. Rather, this guide is meant to provide useful information about available technologies to help end-users make informed decisions about biodetection technology procurement and use. The summaries in this guide are based primarily on vendor-provided information; however, where possible the summaries have been supplemented with additional information obtained from publications, reports, and websites. Manufacturers were contacted and given the opportunity to verify the accuracy of technical specifications, available peer-reviewed references, and pricing. However, all information is subject to change.

Comparing biodetection technologies is challenging in the absence of independent, standardized, third-party testing. Many factors can impact measured performance metrics, such as sensitivity (limit of detection), selectivity (cross-reactivity), and reliability (the occurrence of false-positive or false-negative results). Environmental conditions, sample type, biothreat agent, and degree of sample preparation all impact a technology's performance and make it difficult to directly compare data generated for different technologies tested under different (and often not well-defined) conditions. Vendor-provided performance metrics are listed, and where possible, shown in relation to the quantity or concentration of organism detected. When available, peer-reviewed publications that evaluate the performance of a technology have been used; however, such publications are rare and often outdated due to ongoing technology improvements by vendors. Available peer-reviewed references are listed along with a short summary of findings and the technology's applicability for biological sampling or detection. Publically available peer-

\footnotetext{
${ }^{1}$ Annex B: Competencies for Operations Level Responders Assigned Biological Agent-Specific Tasks. In Standard for Competence of Responders to Hazardous Materials/Weapons of Mass Destruction Incidents; NFPA 472; National Fire Protection Association: Quincy, MA, 2013; pp. 86-91.

${ }^{2}$ Standard Guide for Operational Guidelines for Initial Response to a Suspected Biothreat Agent; ASTM E2770-10; American Society for Testing and Materials, Subcommittee E54.01: West Conshohocken, PA, 2010. DOI: 10.1520/E2770-10.
} 
reviewed references include a hyperlink. A digital object identifier (DOI) number is given for most publications to assist finding the specific article online, however access to the entire electronic publication will depend on the user's or organization's access rights.

The quality of a company's management system can also impact product quality; therefore we provide information about some International Organization for Standardization (ISO) certifications. While having a certified management system helps to validate certain requirements are being met, it is not a prerequisite for producing an effective and high-quality product. In this report we note whether the company is ISO 9001:2008-certified (specifies the requirements of a quality management system) or ISO 13485:2003-certified (specifies the requirements of a quality management system for medical devices). The companies included in this guide may hold additional ISO certifications (e.g., for an environmental management system or an occupational health and safety management system); however, those certifications are not listed here.

Other information that may aid in the evaluation of a products's effectiveness are designations given by the U.S. Department of Homeland Security (DHS) as part of its Support Anti-terrorism by Fostering Effective Technologies (SAFETY) Act of 2002 (www.safetyact.gov). The SAFETY Act, enacted as part of the Homeland Security Act of 2002, facilitates the development and deployment of effective antiterrorism technologies by creating risk- and litigation-management systems. Companies can submit applications to DHS for review of their technology or services. Products can achieve one of three levels of DHS-designated effectiveness:

1. Developmental Testing and Evaluation Designation (DTED) (needs more proof, but potential exists),

2. Designated (proven effectiveness, with confidence of repeatability), or

3. Certified (consistently proven effectiveness, with high confidence of enduring effectiveness).

Products having one or more of these designations or certifications are listed on the SAFETY Act website. ${ }^{3}$ It should be noted that the SAFETY Act website has an "Approved Technologies" tab that lists all products with any designation (DTED, Designated, and/or Certified). Where applicable, SAFETY ACT designations and certifications are noted in this guide, though the lack of a designation or certification does not signify that a product is not effective.

The focus of this guide is on available products for environmental sampling and detection and not products for clinical, food or other sample types. This guide has been organized by grouping similar technologies relevant to responding to potential biological threat incidents. These include the following:

- sample collection kits and tools

- general biological indicator tests including protein, adenosine triphosphate (ATP), deoxyribonucleic acid (DNA)/ribonucleic acid (RNA), and spectroscopic (Fourier Transform Infrared [FTIR]) technologies

- immunoassays

- polymerase chain reaction-based (PCR) detection systems.

Table ES.1-Table ES.4 provide an overview of the technologies described in this guide, including the product, manufacturer, website, cost, and applicable notes.

\footnotetext{
${ }^{3}$ SAFETY Act website - https://www.safetyact.gov
} 
Table ES.1. Sample Collection Products for Potential Biothreats

\begin{tabular}{|c|c|c|c|c|}
\hline Product Name & Manufacturer & Manufacturer Website & Cost & Notes \\
\hline Alexeter Collection Swab ${ }^{\mathrm{TM}}$ & $\begin{array}{l}\text { Alexeter } \\
\text { Technologies, LLC }\end{array}$ & http://www.alexeter.com & $\begin{array}{l}\$ 125 / 25 \mathrm{pk} \\
\$ 5 \text { ea }\end{array}$ & $\begin{array}{l}\text { Sampling swab with integral buffer, mixing } \\
\text { chamber, and dropper. }\end{array}$ \\
\hline NIDS ${ }^{\circledR}$ Multi-Purpose Sampling Kit & $\begin{array}{l}\text { ANP } \\
\text { Technologies }{ }^{\circledR} \text {, Inc. }\end{array}$ & http://anptinc.com/ & $\begin{array}{l}\$ 60 / 2 \mathrm{pk} \\
\$ 30 \text { ea }\end{array}$ & $\begin{array}{l}2 \text { collection tubes, } 2 \text { scoops, } 2 \text { pipettes, } 2 \text { buffer } \\
\text { containing dropper bottles, and } 2 \text { swabs. }\end{array}$ \\
\hline $\begin{array}{l}\text { Sample Collection and Recovery } \\
\text { Device (SCRD) }\end{array}$ & $\begin{array}{l}\text { ASD BioSystems, } \\
\text { Inc. }\end{array}$ & http://www.asdbiosystems.com & $\begin{array}{l}\$ 6000 / 500 \mathrm{pk} \\
\$ 12 \text { ea }\end{array}$ & Sample tube with buffer and swab in cap. \\
\hline $\begin{array}{l}\text { SWIPETM-1 Kit: Large Surface } \\
\text { Sample Collection Kit }\end{array}$ & $\begin{array}{l}\text { New Horizons } \\
\text { Diagnostics, Inc. }\end{array}$ & http://www.nhdiag.com & $\$ 31.50$ ea & Sponge, 25 mL buffer, and slide-lock bag. \\
\hline $\begin{array}{l}\text { SWIPETM-2 Kit: Powder/Small } \\
\text { Surface Sample Collection Kit }\end{array}$ & $\begin{array}{l}\text { New Horizons } \\
\text { Diagnostics, Inc. }\end{array}$ & http://www.nhdiag.com & $\$ 31.50$ ea & $\begin{array}{l}2 \text { swabs, spatula, } 25 \text { mL buffer, collection tube, } \\
\text { and slide-lock bag. }\end{array}$ \\
\hline $\begin{array}{l}\text { SWIPETM-3 Kit: Liquid Sample } \\
\text { Collection Kit }\end{array}$ & $\begin{array}{l}\text { New Horizons } \\
\text { Diagnostics, Inc. }\end{array}$ & http://www.nhdiag.com & $\$ 17.50$ ea & 2 syringes and slide-lock bag. \\
\hline $\begin{array}{l}\text { SWIPETM-4 Kit: Air Sampler } \\
\text { Sample Collection Kit }\end{array}$ & $\begin{array}{l}\text { New Horizons } \\
\text { Diagnostics, Inc. }\end{array}$ & http://www.nhdiag.com & $\$ 24.15$ ea & Collection tube, 25 mL buffer, and slide-lock bag. \\
\hline $\begin{array}{l}\text { SWIPETM SPK: Sample Processing } \\
\text { Kit }\end{array}$ & $\begin{array}{l}\text { New Horizons } \\
\text { Diagnostics, Inc. }\end{array}$ & http://www.nhdiag.com & $\$ 43.50$ ea & $\begin{array}{l}2 \text { syringes, } 2 \text { filters, } 2 \text { collection tubes, } 25 \text { mL } \\
\text { buffer, slide-lock bag, and biohazard bag. }\end{array}$ \\
\hline $\begin{array}{l}\text { All-in-One Sample Collection } \\
\text { Swab }\end{array}$ & $\begin{array}{l}\text { QuickSilver } \\
\text { Analytics, Inc. }\end{array}$ & http://www.chembiokits.com & $\begin{array}{l}\$ 29.16 / 5 \mathrm{pk} \\
\$ 5.83 \text { ea }\end{array}$ & $\begin{array}{l}\text { Sampling swab with integral buffer, mixing } \\
\text { chamber, and dropper. }\end{array}$ \\
\hline B2C ${ }^{\text {тм }}$ Bulk Sample Collection Kit & $\begin{array}{l}\text { QuickSilver } \\
\text { Analytics, Inc. }\end{array}$ & http://www.chembiokits.com & $\$ 32.46$ ea & $\begin{array}{l}\text { Collection containers, tamper tape, swabs, sample } \\
\text { and waste bags, instructions and chain-of-custody } \\
\text { forms. }\end{array}$ \\
\hline $\begin{array}{l}\text { Biological Sampling Kit }\left(\text { BiSKit }^{\mathrm{TM}}\right) \\
\text { - Large Area }\end{array}$ & $\begin{array}{l}\text { QuickSilver } \\
\text { Analytics, Inc. }\end{array}$ & http://www.chembiokits.com & $\$ 51.65$ ea & Large-area sampling kit. \\
\hline $\begin{array}{l}\text { Chemical, Biological, Radiological, } \\
\text { and Explosive (CBRE) Hard Case } \\
\text { Sampling Kit }\end{array}$ & $\begin{array}{l}\text { QuickSilver } \\
\text { Analytics, Inc. }\end{array}$ & http://www.chembiokits.com & $\$ 3398.99$ & $\begin{array}{l}\text { Rugged case. Tools for collecting up to } 31 \text { total } \\
\text { CBRE samples. }\end{array}$ \\
\hline $\begin{array}{l}\text { CBRE Transport Case Sampling } \\
\text { Kit }\end{array}$ & $\begin{array}{l}\text { QuickSilver } \\
\text { Analytics, Inc. }\end{array}$ & http://www.chembiokits.com & $\$ 2207.50$ & $\begin{array}{l}\text { Disposable cart. Tools for collecting up to } 27 \\
\text { total CBRE samples. }\end{array}$ \\
\hline $\begin{array}{l}\text { Incident Response Sampling Kit } \\
\left(\text { IRK }^{\mathrm{TM}}\right)\end{array}$ & $\begin{array}{l}\text { QuickSilver } \\
\text { Analytics, Inc. }\end{array}$ & http://www.chembiokits.com & $\$ 1321.81$ & $\begin{array}{l}\text { For government only. For sampling air, liquids, or } \\
\text { solids. }\end{array}$ \\
\hline $\begin{array}{l}\text { Mini Push Pack }{ }^{\mathrm{TM}} \text { Bio Sampling } \\
\text { Kit }\end{array}$ & $\begin{array}{l}\text { QuickSilver } \\
\text { Analytics, Inc. }\end{array}$ & http://www.chembiokits.com & $\$ 44.61$ ea & $\begin{array}{l}\text { Swab, sponge, scalpel, spatula, collection vial, } \\
\text { pipette, and other supplies. }\end{array}$ \\
\hline
\end{tabular}


Table ES.1. Sample Collection Products for Potential Biothreats (contd)

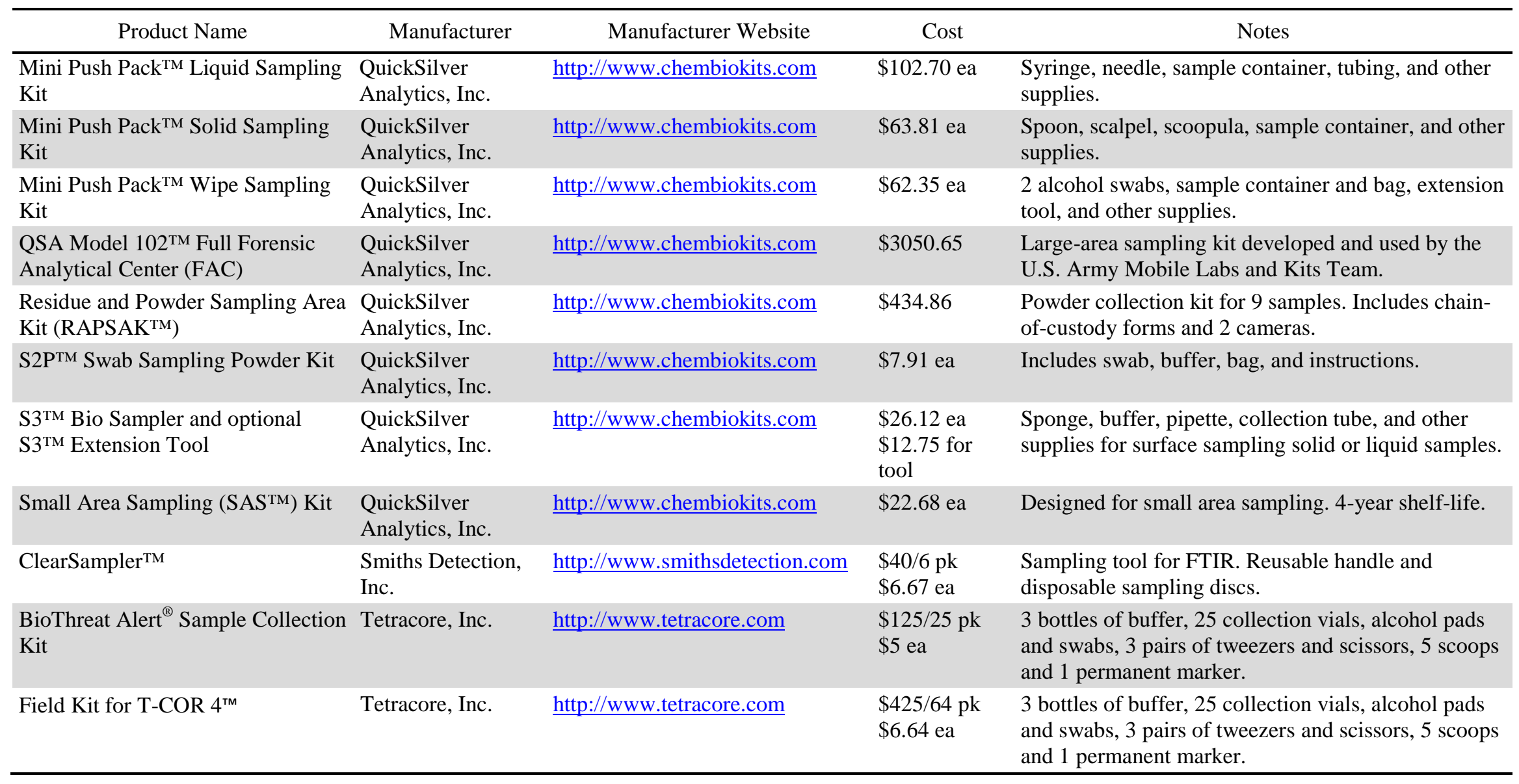


Table ES.2. General Biological Indicator Products for Potential Biothreats

\begin{tabular}{|c|c|c|c|c|c|}
\hline Product Name & Manufacturer & Manufacturer Website & Type of Assay & Cost & Notes \\
\hline \multicolumn{6}{|l|}{ Protein-based } \\
\hline $\begin{array}{l}\text { BioCheck }{ }^{\circledR} \text { Powder } \\
\text { Screening Kit }\end{array}$ & $\begin{array}{l}\text { 20/20 Gene Systems, } \\
\text { Inc., 20/20 } \\
\text { Bioresponse Division }\end{array}$ & http://biocheckinfo.com & $\begin{array}{l}\text { General biological } \\
\text { indicator } \\
\text { (protein and } \mathrm{pH} \text { ) }\end{array}$ & $\begin{array}{l}\$ 687.50 / \\
25 \text { tests } \\
\$ 27.50 / \text { test }\end{array}$ & $\begin{array}{l}\text { Colorimetric protein detection and } \mathrm{pH} \\
\text { test. }\end{array}$ \\
\hline $\begin{array}{l}\text { Threat Agent Screening } \\
\text { Kit (TASKit) } \\
\text { BioScreener }{ }^{\mathrm{TM}}\end{array}$ & Field Forensics, Inc. & http://www.fieldforensics.com & $\begin{array}{l}\text { General biological } \\
\text { indicator } \\
\text { (protein and starch) }\end{array}$ & $\begin{array}{l}\$ 85 / 5 \text { tests } \\
\$ 17 / \text { test }\end{array}$ & $\begin{array}{l}\text { Integral swab and reagents. One } \\
\text { colorimetric protein test and one } \\
\text { colorimetric starch test. }\end{array}$ \\
\hline $\begin{array}{l}\text { HAZCAT Weapons of } \\
\text { Mass Destruction } \\
\text { (WMD) Kit }\end{array}$ & $\begin{array}{l}\text { HazTech Systems, } \\
\text { Inc. }\end{array}$ & http://www.hazcat.com & $\begin{array}{l}\text { General biological } \\
\text { indicator (amino acids) }\end{array}$ & $\$ 5131$ & $\begin{array}{l}\text { All-in-one CBRE detection and } \\
\text { classification kit. Also includes Alexeter } \\
\text { RAID }^{\mathrm{TM}} 8 \text { immunoassay. }\end{array}$ \\
\hline INDIPRO & $\begin{array}{l}\text { Macherey-Nagel, } \\
\text { Inc. }\end{array}$ & http://www.mn-net.com & $\begin{array}{l}\text { General biological } \\
\text { indicator } \\
\text { (protein) }\end{array}$ & $\begin{array}{l}\$ 105 / 60 \text { tests } \\
\$ 1.75 / \text { test }\end{array}$ & Colorimetric protein detection. \\
\hline HazMatID $^{\text {TM }} 360$ & $\begin{array}{l}\text { Smiths Detection, } \\
\text { Inc. }\end{array}$ & http://www.smithsdetection.com & $\begin{array}{l}\text { General biological } \\
\text { indicator (protein) }\end{array}$ & $\$ 55,000$ & $\begin{array}{l}\text { General biological indicator test for } \\
\text { protein using FTIR. }\end{array}$ \\
\hline HazMatID ${ }^{\text {TM }}$ Elite & $\begin{array}{l}\text { Smiths Detection, } \\
\text { Inc. }\end{array}$ & http://www.smithsdetection.com & $\begin{array}{l}\text { General biological } \\
\text { indicator (protein) }\end{array}$ & $\$ 45,000$ & $\begin{array}{l}\text { General biological indicator test for } \\
\text { protein using FTIR. }\end{array}$ \\
\hline HazMatID Ranger ${ }^{\mathrm{TM}}$ & $\begin{array}{l}\text { Smiths Detection, } \\
\text { Inc. }\end{array}$ & http://www.smithsdetection.com & $\begin{array}{l}\text { General biological } \\
\text { indicator (protein) }\end{array}$ & $\$ 35,000$ & $\begin{array}{l}\text { General biological indicator test for } \\
\text { protein using FTIR. }\end{array}$ \\
\hline TruDefender $^{\mathrm{TM}}$ FT/FTi & $\begin{array}{l}\text { Thermo Fisher } \\
\text { Scientific, Inc. }\end{array}$ & http://www.ahurascientific.com & $\begin{array}{l}\text { General biological } \\
\text { indicator (protein) }\end{array}$ & $\begin{array}{l}\$ 45,000 \mathrm{FT} \\
\$ 46,500 \mathrm{FTi}\end{array}$ & $\begin{array}{l}\text { General biological indicator test for } \\
\text { protein using FTIR. }\end{array}$ \\
\hline \multicolumn{6}{|l|}{ ATP-based } \\
\hline $\begin{array}{l}\text { Clean-Trace }{ }^{\mathrm{TM}} \text { Surface } \\
\text { ATP }\end{array}$ & $3 \mathrm{M}$ & $\underline{\text { http://solutions.3m.com }}$ & $\begin{array}{l}\text { General biological } \\
\text { indicator } \\
\text { (ATP) }\end{array}$ & $\begin{array}{l}\$ 254 / 100 \text { tests } \\
\$ 2.54 / \text { test }\end{array}$ & $\begin{array}{l}\text { Colorimetric test for live cells using } \\
\text { ATP as an indicator. Optical reader } \\
\text { (\$2900) required. }\end{array}$ \\
\hline PROFILE $^{\circledR} 1$ & $\begin{array}{l}\text { New Horizons } \\
\text { Diagnostics, Inc. }\end{array}$ & $\underline{\text { http://www.nhdiag.com }}$ & $\begin{array}{l}\text { General biological } \\
\text { indicator } \\
\text { (ATP) }\end{array}$ & $\begin{array}{l}\$ 450 / 100 \text { tests } \\
\$ 4.50 / \text { test }\end{array}$ & $\begin{array}{l}\text { Test for live bacterial cells using ATP as } \\
\text { a marker. Optical reader }(\$ 5000) \\
\text { required. }\end{array}$ \\
\hline \multicolumn{6}{|l|}{ DNA-based } \\
\hline Prime Alert ${ }^{\circledR}$ & GenPrime, Inc. & http://www.genprime.com & $\begin{array}{l}\text { General biological } \\
\text { indicator } \\
\text { (DNA) }\end{array}$ & $\$ 70 /$ test & $\begin{array}{l}\text { Colorimetric test with a separate } \\
\text { immunoassay toxin test. Optical reader } \\
(\$ 12,000) \text { required. }\end{array}$ \\
\hline
\end{tabular}


Table ES.3. Immunoassay-Based Detection Products for Potential Biothreats

\begin{tabular}{|c|c|c|c|c|}
\hline Product Name & Manufacturer & Manufacturer Website & Cost & Notes \\
\hline $\mathrm{BADD}^{\mathrm{TM}}$ & $\begin{array}{l}\text { AdVnt Biotechnologies, } \\
\text { LLC }\end{array}$ & http://www.advnt.org & \$24.50/agent & 1-agent assays. 10 assays per box. \\
\hline Pro Strips ${ }^{\mathrm{TM}}$ & $\begin{array}{l}\text { AdVnt Biotechnologies, } \\
\text { LLC }\end{array}$ & http://www.advnt.org & $\begin{array}{l}\text { \$69.95/assay } \\
\text { \$13.99/agent }\end{array}$ & 5-agent assays. 10 assays per box. \\
\hline $\begin{array}{l}\text { BioDetect }{ }^{\mathrm{TM}} \text { Test Strips with } \\
\text { optional Guardian or Defender } \\
\text { reader }\end{array}$ & $\begin{array}{l}\text { Alexeter Technologies, } \\
\text { LLC }\end{array}$ & http://www.alexeter.com & \$27.40/agent & $\begin{array}{l}\text { 1-agent assays. } 25 \text { assays per box. Optional } \\
\text { optical readers: Guardian (\$7500) or Defender } \\
\text { (\$9995). }\end{array}$ \\
\hline RAID $^{\text {TM }}$ Multi-Test Strips & $\begin{array}{l}\text { Alexeter Technologies, } \\
\text { LLC }\end{array}$ & http://www.alexeter.com & $\begin{array}{l}\text { \$49.50-\$99.50/assay } \\
\$ 12.44-\$ 16.50 / \text { agent }\end{array}$ & $\begin{array}{l}\text { 5- or } 8 \text {-agent pathogen assays, 3-agent toxin } \\
\text { assay. } 10 \text { assays per box. }\end{array}$ \\
\hline NIDS $^{(B)}$ assays and optical reader & ANP Technologies ${ }^{\circledR}$, Inc. & $\underline{\text { http://anptinc.com/ }}$ & $\begin{array}{l}\text { \$60-\$80/assay } \\
\text { \$20/agent }\end{array}$ & $\begin{array}{l}3 \text { and } 4 \text {-agent assays. Assays sold individually. } \\
\text { Optional optical reader (\$6900). }\end{array}$ \\
\hline IMASS assays & BBI Detection & http://www.bbidetection.com & $\begin{array}{l}\text { \$120/assay } \\
\text { \$15/agent }\end{array}$ & $\begin{array}{l}\text { 8-agent assay with integral sampling sponge } \\
\text { and buffer. } 10 \text { assays per box. }\end{array}$ \\
\hline $\begin{array}{l}\text { ENVI Assay System and } \\
\text { optional reader }\end{array}$ & Environics, Inc. & http://www.environicsusa.com & \$40-\$45/agent & $\begin{array}{l}\text { 1-agent assays. } 10 \text { assays per box. Optional } \\
\text { optical reader }(\$ 3452) \text { requires ChemPro }{ }^{\circledR} 100 \\
\text { module }(\$ 14,995) \text { or PC software }(\$ 540) \text { PC } \\
\text { not included. }\end{array}$ \\
\hline Toxin Screen & GenPrime, Inc. & http://www.genprime.com & $\begin{array}{l}\text { \$95/assay } \\
\text { \$31.67/agent }\end{array}$ & 3-agent assay. Assays sold individually. \\
\hline Smart ${ }^{\mathrm{TM}}$ II & $\begin{array}{l}\text { New Horizons } \\
\text { Diagnostics, Inc. }\end{array}$ & http://www.nhdiag.com & \$22/agent & 1-agent assays. 25 assays per box. \\
\hline CANARY $^{\circledR}$ Zephyr & PathSensors, Inc. & http:www.pathsensors.com & \$16/agent & $\begin{array}{l}\text { Automated 1-agent cell-based assays (5 assays } \\
\text { per container) and detection instrument } \\
(\$ 23,490) \text {. }\end{array}$ \\
\hline $\begin{array}{l}\text { BIOSENSOR }{ }^{\mathrm{TM}} 2200 \mathrm{R}: \\
\text { Automated, Multianalyte } \\
\text { Bioassay Detection System }\end{array}$ & QTL Biodetection, LLC & http://us.msasafety.com & $\begin{array}{l}\text { \$80-100/assay } \\
\text { \$50-\$80/agent }\end{array}$ & $\begin{array}{l}\text { Automated } 1-\text { and } 2 \text {-agent assays and detection } \\
\text { system }(\$ 16,533) \text {. Assays sold in various } \\
\text { packaged configurations. }\end{array}$ \\
\hline $\begin{array}{l}\text { BioHawk }^{(\mathbb{R})} \text { : Automated, } \\
\text { Multianalyte Bioassay Detection } \\
\text { System }\end{array}$ & $\begin{array}{l}\text { Research International, } \\
\text { Inc. }\end{array}$ & http://resrchintl.com & $\begin{array}{l}\text { \$250/assay } \\
\text { \$31.25/agent }\end{array}$ & $\begin{array}{l}\text { Automated } 8 \text {-agent assay (10 assays per box) } \\
\text { and detection system }(\$ 65,000) \text { with integral air } \\
\text { sampler. }\end{array}$ \\
\hline $\begin{array}{l}\text { RAPTOR }{ }^{\mathrm{TM}} \text { : Automated, } \\
\text { Multianalyte Bioassay Detection } \\
\text { System }\end{array}$ & $\begin{array}{l}\text { Research International, } \\
\text { Inc. }\end{array}$ & http://resrchintl.com & $\begin{array}{l}\text { \$200/assay } \\
\text { \$50/agent }\end{array}$ & $\begin{array}{l}\text { Automated } 4 \text {-agent assay (10 assays per box) } \\
\text { and detection system }(\$ 50,000) \text {. }\end{array}$ \\
\hline $\begin{array}{l}\mathrm{RAMP}^{\circledR} \text { assays and optical } \\
\text { reader }\end{array}$ & $\begin{array}{l}\text { Response Biomedical } \\
\text { Corp. }\end{array}$ & http://responsebio.com & \$23.96-\$27/agent & $\begin{array}{l}\text { 1-agent assays. } 25 \text { assays per box. Required } \\
\text { optical reader (\$6995). }\end{array}$ \\
\hline $\begin{array}{l}\text { BioThreat Alert }{ }^{\circledR} \text { assays and } \\
\text { optical reader }\end{array}$ & Tetracore, Inc. & http://www.tetracore.com & \$24.20/agent & $\begin{array}{l}\text { 1-agent assays. } 25 \text { assays per box. Optional } \\
\text { optical reader }(\$ 5500) \text {. }\end{array}$ \\
\hline
\end{tabular}


Table ES.4. PCR-Based Detection Products for Potential Biothreats

\begin{tabular}{|c|c|c|c|c|}
\hline Product Name & Manufacturer & Manufacturer Website & Cost & Notes \\
\hline FilmArray $^{\circledR}$ & $\begin{array}{l}\text { BioFire } \\
\text { Diagnostics, Inc. }\end{array}$ & http://www.biofiredx.com & $\begin{array}{l}\text { \$180/assay } \\
\text { \$10.59/agent } \\
\text { (\$6.43/target) }\end{array}$ & $\begin{array}{l}\text { 17-agent assay ( } 28 \text { targets) with internal control. } 6 \\
\text { assays per box. AC power. Instrument cost }=\$ 49,500 \text {. }\end{array}$ \\
\hline R.A.P.I.D. ${ }^{\circledR}$ & $\begin{array}{l}\text { BioFire } \\
\text { Diagnostics, Inc. }\end{array}$ & http://www.biofiredx.com & \$9.23/agent & $\begin{array}{l}\text { 1-agent assays. } 48 \text { assays per box. Up to } 32 \text { parallel } \\
\text { sample analysis. Battery power. Instrument cost }= \\
\$ 55,000 \text {. }\end{array}$ \\
\hline RAZOR ${ }^{\circledR} \mathrm{EX}$ & $\begin{array}{l}\text { BioFire } \\
\text { Diagnostics Inc. }\end{array}$ & $\underline{\text { http://www.biofiredx.com }}$ & $\begin{array}{l}\text { \$200/assay } \\
\text { \$20/agent }\end{array}$ & $\begin{array}{l}\text { 10-agent assay with internal control. 1-agent (3-target) } \\
\text { assay also available for anthrax }(\$ 180) \text {. Assays sold } \\
\text { individually. Battery power. Instrument cost }=\$ 38,500 \text {. }\end{array}$ \\
\hline POCKIT & $\begin{array}{l}\text { Gene Reach } \\
\text { USA }\end{array}$ & http://www.genereach-us.com & \$15 agent & $\begin{array}{l}\text { 1-agent assays. } 24 \text { assays per box. No internal control. } \\
\text { Battery power. Instrument cost }=\$ 5900 \text {. }\end{array}$ \\
\hline Bio-Seeq ${ }^{\mathrm{TM}}$ PLUS & $\begin{array}{l}\text { Smiths } \\
\text { Detection, Inc. }\end{array}$ & http://www.smithsdetection.com & \$29/agent & $\begin{array}{l}\text { 1-agent assays with internal control. } 10 \text { assays per box. } \\
\text { Battery power. Instrument cost }=\$ 35,000 \text {. }\end{array}$ \\
\hline $\mathrm{T}-\mathrm{COR} 4^{\mathrm{TM}}$ & Tetracore, Inc. & http://www.tetracore.com & \$12.00/agent & $\begin{array}{l}\text { 1-agent assays with internal control. } 64 \text { assays per box. } \\
\text { Battery power. Instrument cost }=\$ 16,000 \text {. }\end{array}$ \\
\hline
\end{tabular}





\section{Acronyms and Abbreviations}

ASTM

ATP

ATR

BHI

CBRE

CDC

CFU

DHS

DoD

DNA

DTED

ECBC

EEE

ELISA

EPA

FAC

FBI

FDA

FTIR

GE

GPS

HazMat

ILV

ISO

JBAIDS

LFA

LFD

LOD

LRN

$\mathrm{MD}$

NFPA $^{\circledR}$

NIAID

NYDOH

PBS

PCR

PDA

PFU

pg

PNNL

RF

RLU
American Society for Testing and Materials

adenosine triphosphate

attenuated total reflection

brain heart infusion

chemical, biological, radiological, and explosive

Center for Disease Control

colony-forming units (equivalent to number of organisms)

U.S. Department of Homeland Security

U.S. Department of Defense

deoxyribonucleic acid

Developmental Testing and Evaluation Designation

Edgewood Chemical and Biological Center

Eastern equine encephalitis

enzyme-linked immunosorbent assay

U.S. Environmental Protection Agency

Forensic Analytical Center

Federal Bureau of Investigation

Food and Drug Administration

Fourier Transform Infrared

genome equivalent

global positioning system

hazardous materials

independent laboratory validation

International Organization for Standardization

Joint Biological Agent Identification and Diagnostic System

lateral flow assay

lateral flow device

limit of detection

Laboratory Response Network

(AOAC) Method Developer

National Fire Protection Association

National Institute of Allergy and Infectious Disease

New York State Department of Health

phosphate buffered saline

polymerase chain reaction

personal digital assistant

plaque-forming units (equivalent to number of viruses)

picrogram (one trillionth of a gram)

Pacific Northwest National Laboratory

radio frequency

relative light units 
RNA

SAFETY Act

SARS

SEB

SPADA

TICS

TIMS

VEE

WEE

WMD ribonucleic acid

The Support Anti-terrorism by Fostering Effective Technologies Act severe acute respiratory syndrome

Staphylococcal Enterotoxin type B

Stakeholder Panel on Agent Detection Assays

toxic industrial chemicals

toxic industrial materials

Venezuelan equine encephalitis

Western equine encephalitis

weapon of mass destruction 


\section{Contents}

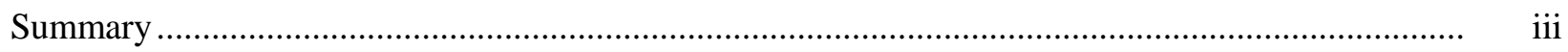

Acronyms and Abbreviations .................................................................................................. xi

1.0 Biothreat Diseases and Causative Agents...................................................................... 1.1

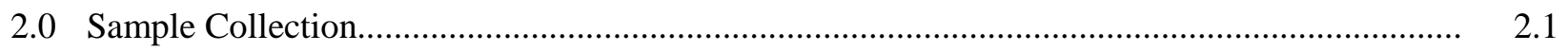

Alexeter Technologies, LLC: Alexeter Collection Swab ${ }^{\mathrm{TM}}$........................................................ 2.3

ANP Technologies, Inc.: NIDS ${ }^{\circledR}$ Multi-Purpose Sampling Kit............................................... 2.4

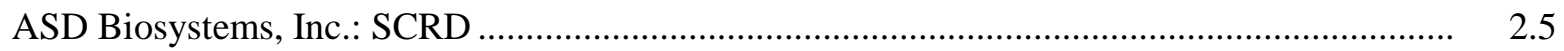

New Horizons Diagnostics, Inc.: SWIPE ${ }^{\mathrm{TM}}$ Kits............................................................... $\quad 2.7$

QuickSilver Analytics, Inc.: Sampling Kits .................................................................... 2.8

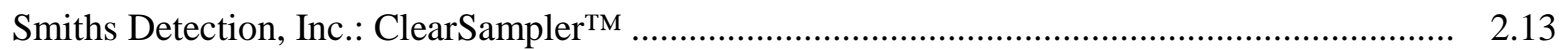

Tetracore, Inc.: BioThreat Alert ${ }^{\circledR}$ Sample Collection Kit...................................................... 2.14

Tetracore, Inc.: Field Kit for T-COR 4 ${ }^{\mathrm{TM}}$.............................................................................. 2.15

3.0 General Biological Indicator Tests ................................................................................

20/20 Gene Systems, Inc.: BioCheck ${ }^{\circledR}$ Powder Screening Kit .................................................. 3.4

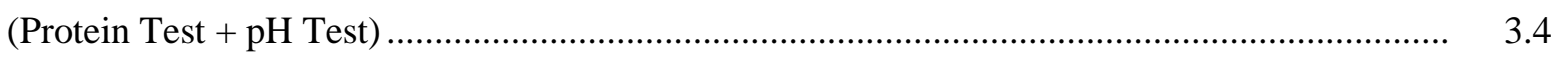

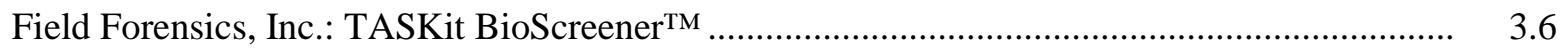

(Protein Test + Starch Test) ....................................................................................................

HazTech Systems, Inc.: KT7001 HAZCAT WMD Kit.........................................................

(Protein Tests + Various Assays) …..................................................................................... 3.7

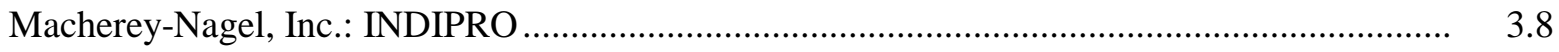

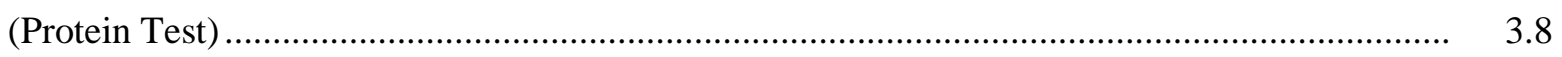

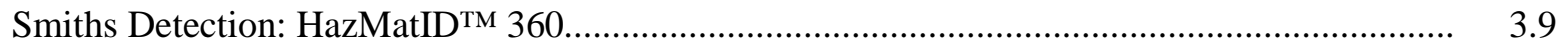

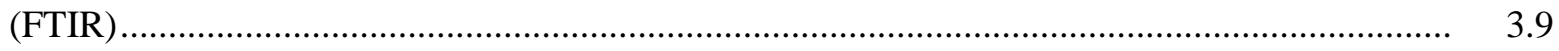

Smiths Detection: HazMatID ${ }^{\mathrm{TM}}$ Elite ............................................................................... 3.10

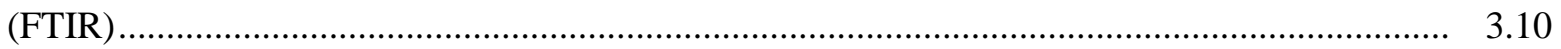

Smiths Detection: HazMatID ${ }^{\mathrm{TM}}$ Ranger ............................................................................ 3.11

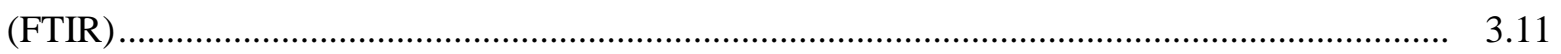

Thermo Scientific: TruDefender ${ }^{\circledR}$ FT and FTi ............................................................. 3.12

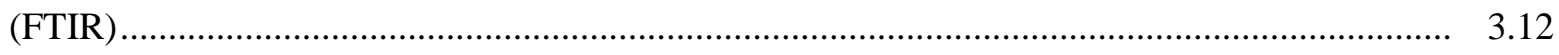

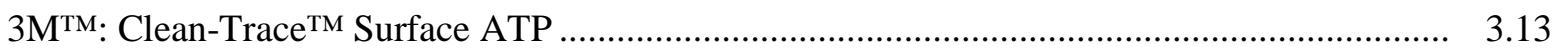

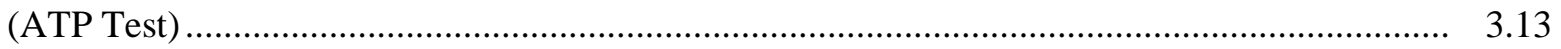

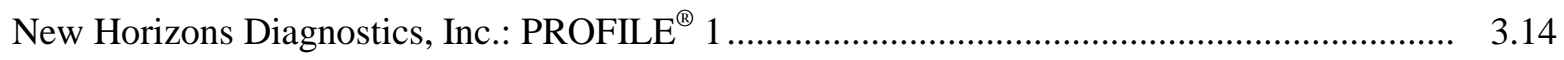

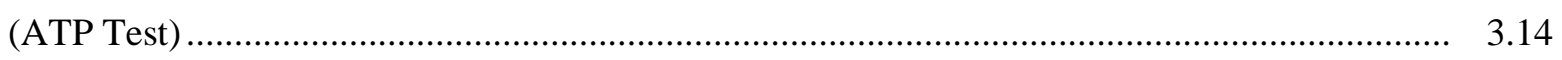

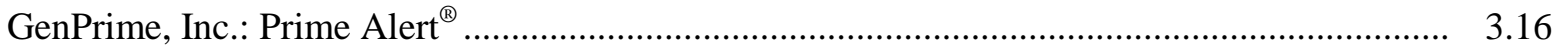

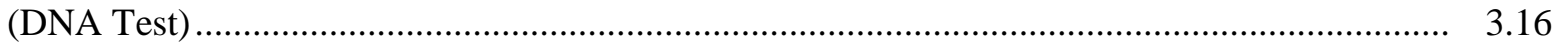

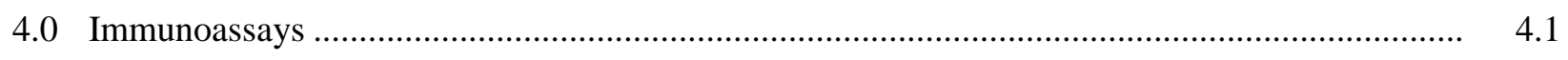

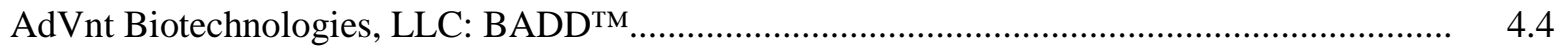




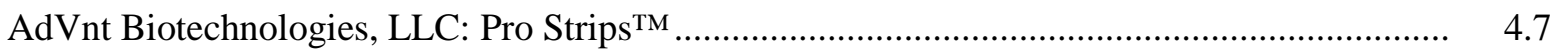

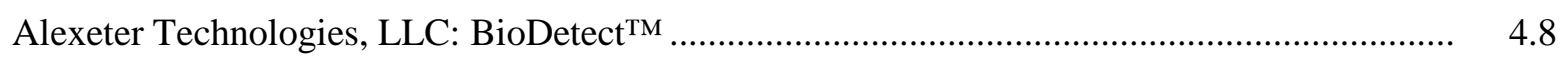

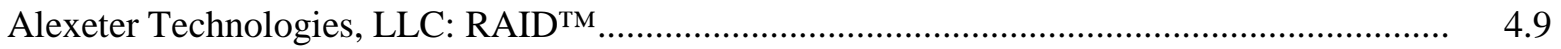

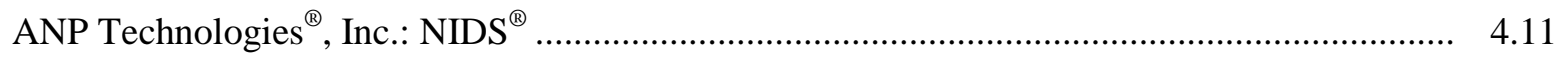

Environics, Inc.: ENVI Assay System Gold..................................................................... 4.14

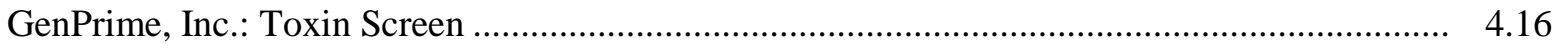

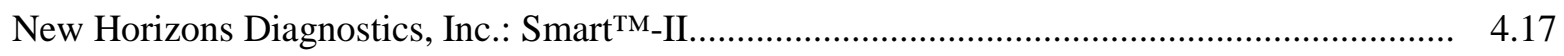

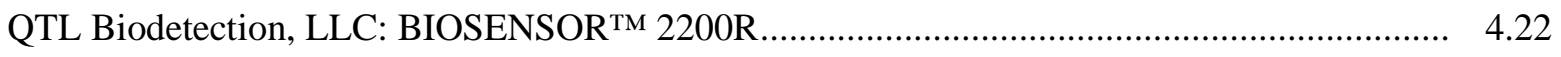

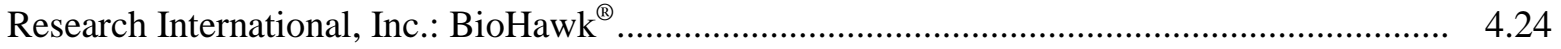

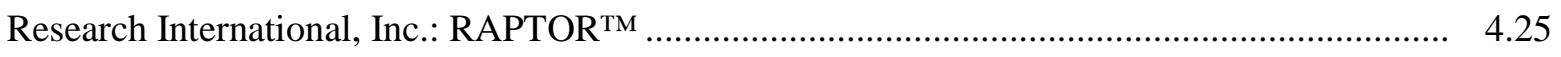

Tetracore, Inc.: BioThreat Alert ${ }^{\circledR}$ Reader MX.................................................................. 4.31

5.0 PCR-Based Detection Systems ............................................................................................ 5.1

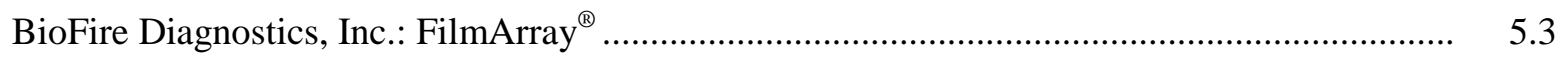

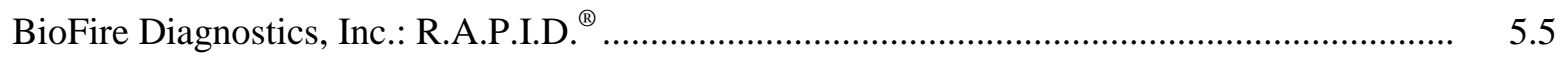

BioFire Diagnostics, Inc.: RAZOR ${ }^{\circledR}$ EX .................................................................... 5.6

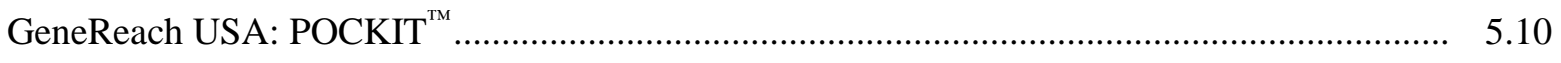

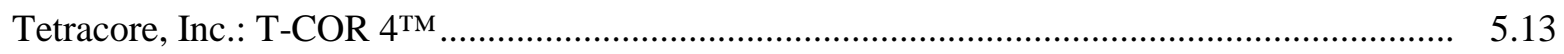

\section{Tables}

Table ES.1. Sample Collection Products for Potential Biothreats ................................................... v

Table ES.2. General Biological Indicator Products for Potential Biothreats ..................................... vii

Table ES.3. Immunoassay-Based Detection Products for Potential Biothreats.................................. viii

Table ES.4. PCR-Based Detection Products for Potential Biothreats .............................................. ix

Table 1.1. Diseases/Toxins for Category A Priority Pathogens....................................................... 1.1

Table 1.2. Diseases/Toxins for Category B Priority Pathogens.......................................................... 1.2

Table 1.3. Diseases/Toxins for Category C Priority Pathogens........................................................ 1.2 


\subsection{Biothreat Diseases and Causative Agents}

Important Note: Biothreat agent names used throughout this guide are those specified by equipment manufacturers. Often, vendors reference a disease instead of its causative agent. One prevalent example is the use of anthrax, a disease caused by the organism Bacillus anthracis. These tests detect the organism, not the disease, yet anthrax and Bacillus anthracis are often used interchangeably in the biodetection technology marketplace, as are plague and Yersinia pestis.

Table 1.1-Table 1.3 list diseases/toxins and their causative agents/sources. The tables are separated into three categories according to the priority pathogen lists at the Center for Disease Control (CDC) website. ${ }^{1}$ The website also includes a wealth of information on bioterrorism, different biothreats and the diseases they cause, including basic descriptions of biothreat agents, risk factors, symptoms and medical care. The priority pathogen lists are periodically reviewed and revised in conjunction with the U.S. Department of Homeland Security (DHS) and the CDC. First responders and the public health system must be prepared to address various biological agents, even those that are uncommon in the United States.

High-priority pathogens (i.e., Category A) are those organisms or biological agents that pose a risk to national security due to:

- ease of dissemination or transmission among people

- potential for high mortality rates

- potential for major public health impacts including public panic/social disruption

- special actions required for public health preparedness.

Table 1.1. Diseases/Toxins for Category A Priority Pathogens

\begin{tabular}{ll}
\hline \multicolumn{1}{c}{ Disease/Toxin } & \multicolumn{1}{c}{ Causative Agent/Source } \\
\hline Anthrax & Bacillus anthracis \\
Botulism & Clostridium botulinum toxin \\
Plague & Yersinia pestis \\
Smallpox & variola (or orthopox) virus \\
Tularemia & Francisella tularensis \\
Viral hemorrhagic fevers & Filoviruses, for example: \\
& $\bullet$ Ebola \\
& - Marburg \\
& Arenaviruses, for example: \\
& $\bullet$ Lassa \\
& - Machupo \\
\hline
\end{tabular}

\footnotetext{
${ }^{1}$ CDC website - http://www.bt.cdc.gov/agent/agentlist-category.asp
} 
Category B pathogens are the second highest priority organisms/biological agents and are those that have moderate ease of dissemination, moderate morbidity rates and low mortality rates, and require specific enhancements of the CDC's diagnostic capacity and disease surveillance.

Table 1.2. Diseases/Toxins for Category B Priority Pathogens

\begin{tabular}{ll}
\hline \multicolumn{1}{c}{ Disease/Toxin } & \multicolumn{1}{c}{ Causative Agent/Source } \\
\hline Brucellosis & Brucella species \\
Epsilon toxin & Clostridium perfringens \\
Food Safety Threats & Salmonella species \\
Bacterial infections & Escherichia coli (0157:H7) \\
& Shigella \\
Glanders & Burkholderia mallei \\
Melioidosis & Burkholderia pseudomallei \\
Psittacosis & Chlamydia psittaci \\
Q fever & Coxiella burnetii \\
Ricin toxin & Ricinus communis (castor beans) \\
Staphylococcal Enterotoxin B (SEB) & Staphylococcus aureus \\
Typhus fever & Rickettsia prowazekii \\
Water Safety Threats & \\
Bacterial infections & Vibrio cholerae \\
Protozoal infections & Cryptosporidium parvum \\
Viral encephalitis & Alphaviruses \\
& $\bullet$ Venezuelan equine encephalitis (VEE) \\
& $\bullet$ Eastern equine encephalitis (EEE) \\
& $\bullet$ Western equine encephalitis(WEE) \\
\hline
\end{tabular}

The third highest priority organisms/biological agents (i.e., Category C) include emerging pathogens that could be engineered for mass dissemination in the future due to their ease of availability, ease of production and dissemination, and potential for high morbidity and mortality rates.

Table 1.3. Diseases/Toxins for Category C Priority Pathogens

\begin{tabular}{cl}
\hline & Causative \\
Disease/Toxin & Agent/Source \\
\hline Emerging infectious diseases & Nipah virus \\
& Hantavirus \\
\hline
\end{tabular}




\subsection{Sample Collection}

While some biodetection assays provide tools for sampling, many do not. Sampling kits are available in a wide range of configurations. Typically, these kits consist of a swab or scoop to pick up the sample and a collection vial with buffer (often phosphate buffered saline [PBS]) to solubilize or suspend the sample. Additional features may include integrated droppers for sample dispensing, chain-of-custody forms, or sample preparation for removal of potential assay inhibitors. Some sample containers or outer packaging bags can be sealed and are designed to be dunked into a decontamination solution such as bleach, so that a sample can be sent to a centralized laboratory or tested in the warm zone (outside of the hot [contaminated] zone). Standardized practices for the collection of visible powders that are suspected of being biothreat agents have been developed by ASTM (1).

For the most part, the sampling kits listed in this guide are designed to collect powders, but some will also work with liquids. With a few exceptions, the majority of the kits provide no sample processing to remove potential assay inhibitors. Most kits are designed to suspend suspect material in a buffered solution for downstream analysis. Whereas most of the kits themselves have not been formally evaluated, primary components of the kits (e.g., swabs, wipes, and sponges) have been evaluated for their ability to recover Bacillus species spores from various surfaces (2-3). A large number of sample collection studies have been conducted and only a few examples are given here.

Most of the available literature on sampling materials concerns recovery efficiency. Recovery efficiency is affected by a number of factors including the sampling materials (cotton, foam, polyester, etc.), surface area covered, type of surface (e.g., stainless steel, tile, carpet, drywall), the assay used to quantify recovery, and even the spore deposition method (2-3). With these studies, it is important to emphasize that there is an underlying assumption that high spore/agent concentrations will be present in a small area. The range of results in these published studies suggests that the best approach for sampling suspicious powders during suspected incidents will depend on factors such as the amount of material available, the sampling material, the type of sampling surface and the downstream detection method(s).

In summary, when choosing a sampling kit, the potential downstream detection technology should be considered. Care should be exercised to ensure that, especially when buffers are used, the final solubilized or suspended sample is compatible with the downstream detection methods. For example, some sample buffers have components that can interfere with immunoassays or polymerase chain reaction (PCR)-based detection systems. Always verify with the sampling kit and detection technology manufacturers that the sampling kit buffer is compatible with the chosen detection approach.

\section{References}

1. Standard Practices for Bulk Sample Collection and Swab Sample Collection of Visible Powders Suspected of Being Biothreat Agents from Nonporous Surfaces; ASTM E2458-10; American Society for Testing and Materials, Subcommittee E54.01: West Conshohocken, PA, 2010. DOI: 10.1520/E2458-10.

This standard provides detailed step-by-step guidance for collection of bulk (Method A) and residual (Method B) suspicious powders after a sample has been screened for explosive, radiological, 
and acute chemical hazards. These sampling practices are performed as part of a risk assessment (i.e., hazard assessment and threat evaluation) in coordination with the Federal Bureau of Investigation (FBI) as described in ASTM E2770-10. The bulk sample collected by Method A is intended to be packaged and transported to a Laboratory Response Network (LRN) reference lab. Swab sampling of residual powder (Method B) can be used for onsite biological screening. This standard provides a detailed list of sampling and packaging equipment and supplies for each method. Both methods use a two-person team (sampler and assistant sampler). Multiple example forms provided include a fieldscreening results form, a sample collection sheet, a chain-of-custody form, and example biothreat tracking and specimen submission forms from the New York State Department of Health and Massachusetts Department of Public Health.

2. Rose, L. J., L. Hodges, H. O. O'Connell, and J. Nobel-Wang. National Validation Study of a Cellulose Sponge Wipe-Processing Method for Use After Sampling Bacillus anthracis Spores from Surfaces. Appl. Environ. Microbiol. 2011, 77, 8355-8359. DOI: 10.1128/AEM.05377-11.

Nine LRN laboratories evaluated 3M cellulose sponges (pre-moistened) for sampling Bacillus anthracis Sterne strain spores from 10-in. square steel surfaces. Spores, dust, and background organisms were applied to the surfaces at levels ranging from 10-10,000 spores. Approximately seven sponges and two positive control wipes were tested at each site. Percent recovery ranged from 24 to 32\% with coefficients of variation (\% CV) of 20 of $31 \%$ for between-lab and 20 to $69 \%$ for within-lab. The presence of dust and background organisms did not appreciably impact the ability to detect Bacillus anthracis. The low levels of spores used in this study highlighted the large variability inherent in the sampling process.

3. Edmonds, J. M., P. J. Collett, E. R. Valdes, E. W. Skowronski, G. J. Pellar, and P. A. Emanuel. Surface Sampling of Spores in Dry-Deposition Aerosols. Appl. Environ. Microbiol. 2009, 75, 39-44. DOI: 10.1128/AEM.01563-08.

This study compared recovery of spores deposited onto surfaces in dry (aerosol) and liquid form (spores in liquid form were applied to a surface followed by drying). Four different 2-cm x 5-cm surfaces were used (i.e., glass, painted steel, polycarbonate, and vinyl tile). Four different swab materials (3 to 4 replicates each) were used: Fisher Scientific Puritan cotton swabs, Fisher Scientific FisherBrand Dacrontipped swabs, Starplex Scientific rayon-tipped swabs, and scientific supplier VWR Critical Swab polyurethane macrofoam-tipped swab.. Percent recoveries and reproducibility (\% CV) were impacted by the surface material, the swab type, and the spore deposition method. CVs ranged from 10 to 35\% across all variables studied and were consistently nearly twice as high for liquid than for aerosol-deposited spores on vinyl tile. All swab types performed well for collection from glass surfaces after liquid deposition (82 to 89\% recovery), but were lower for aerosol deposition (62 to 65\%). Spore recovery from painted steel surfaces was generally lowest (42 to 58\%) for all swab types and deposition methods. Different swabs gave higher recoveries depending on the sample surface and spore deposition method. The macrofoam swab performed better in most, but not all, instances. In a separate experiment, the recovery of liquid-deposited spores from glass surfaces was shown to be dependent on the number of spores present on the surface. Four spore concentrations $\left(10^{4}, 10^{5}, 10^{6}\right.$ and $10^{7}$ had recoveries of 42,61 , 76 , and $93 \%$, respectively. 


\section{Alexeter Technologies, LLC: Alexeter Collection Swab ${ }^{\text {TM }}$}

Product Link: http://www.alexeter.com/biow/products/products/accessories/CollectionSwab.asp

Contact: Tom Fryzel (tfryzel@alexeter.com)

Phone: (877) 591-5571 Manufacturer's website: http://www.alexeter.com

\section{Technology Summary}

The Alexeter Collection Swab ${ }^{\mathrm{TM}}$ combines onsite sampling of biological agents and sample preparation for fieldtesting by immunoassay or PCR-based assay. The device includes a Dacron ${ }^{\circledR}$-tipped swab, self-contained PBS buffer for sample solubilization, pre-filter, and transfer sample dropper all-in-one device. The all-in-one device minimizes sample transfer operations and is provided in a convenient single package. Alexeter also offers a BioDetect ${ }^{\mathrm{TM}}$ Standard Collection Kit for use with BioDetect $^{\mathrm{TM}}$ immunoassay test strips that contains 25 separate swabs, 5 spatulas, 25 sample vials, 3 bottles of buffer, $100 \mathrm{pH}$ strips, 1 permanent marker and instructions (\$107 [\$4.28 ea; picture not available]).

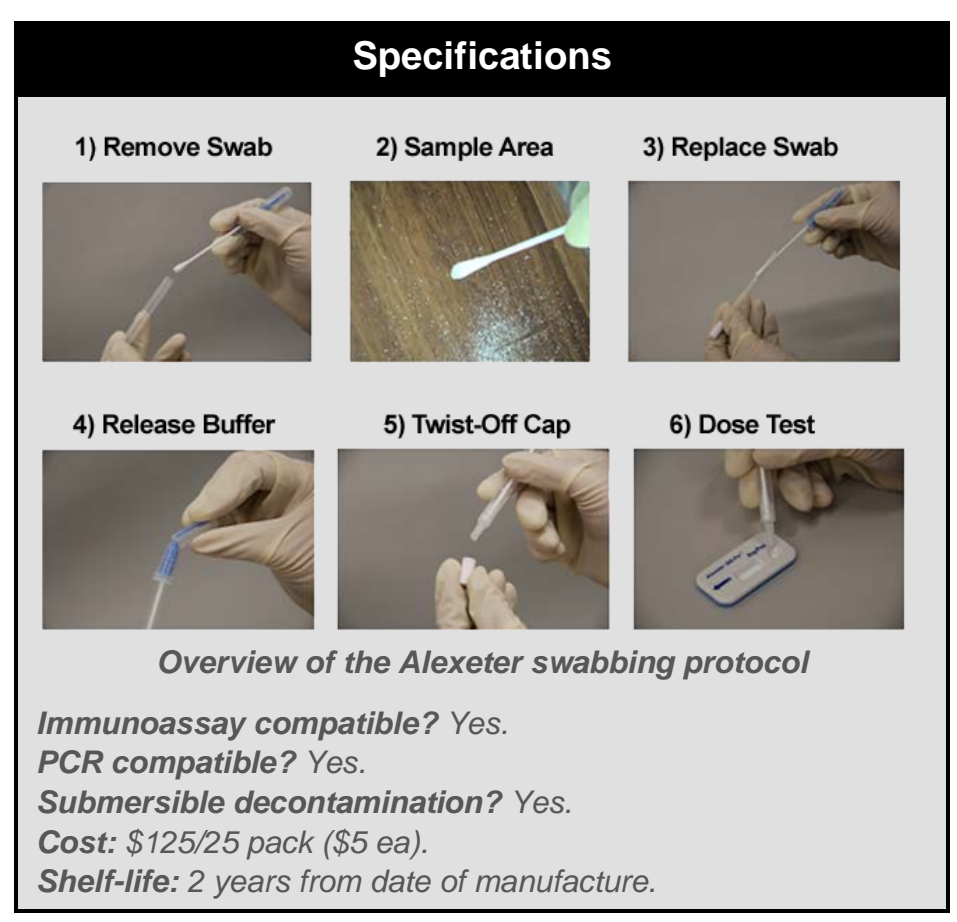

\section{Compatibility with Biodetection Assays}

The Alexeter Collection Swab ${ }^{\mathrm{TM}}$ is designed to be used with Alexeter BioDetect ${ }^{\mathrm{TM}}$ immunoassay test strips and is also compatible with PCR-based detection.

\section{Peer-Reviewed References}

No peer-reviewed publications were found that demonstrate the use of this product for the collection of potential biothreats. 


\section{ANP Technologies, Inc.: NIDS ${ }^{\circledR}$ Multi-Purpose Sampling Kit}

Product Link: http://anptinc.com/index.php?option=com_content\&view=article\&id=94\&Itemid=81

Contact: Ray Yin (ray@anptinc.com)

Phone: (302) 283-1730 Manufacturer's website: http://anptinc.com

\section{Technology Summary}

This kit contains supplies for collection of two separate samples. A kit includes two $50 \mathrm{~mL}$ free standing collection tubes, two scoops, two transfer pipettes, two $15 \mathrm{~mL}$ dropper bottles containing $5 \mathrm{~mL}$ of PBST-K buffer, and two swabs.

The management system governing the manufacture of this product is International Organization for Standardization (ISO) 9001:2008-certified (specifies the requirements of a quality management system).

\section{Compatibility with Biodetection Assays}

The Multi-Purpose Sampling Kit is designed for use with ANP Technologies' immunoassay

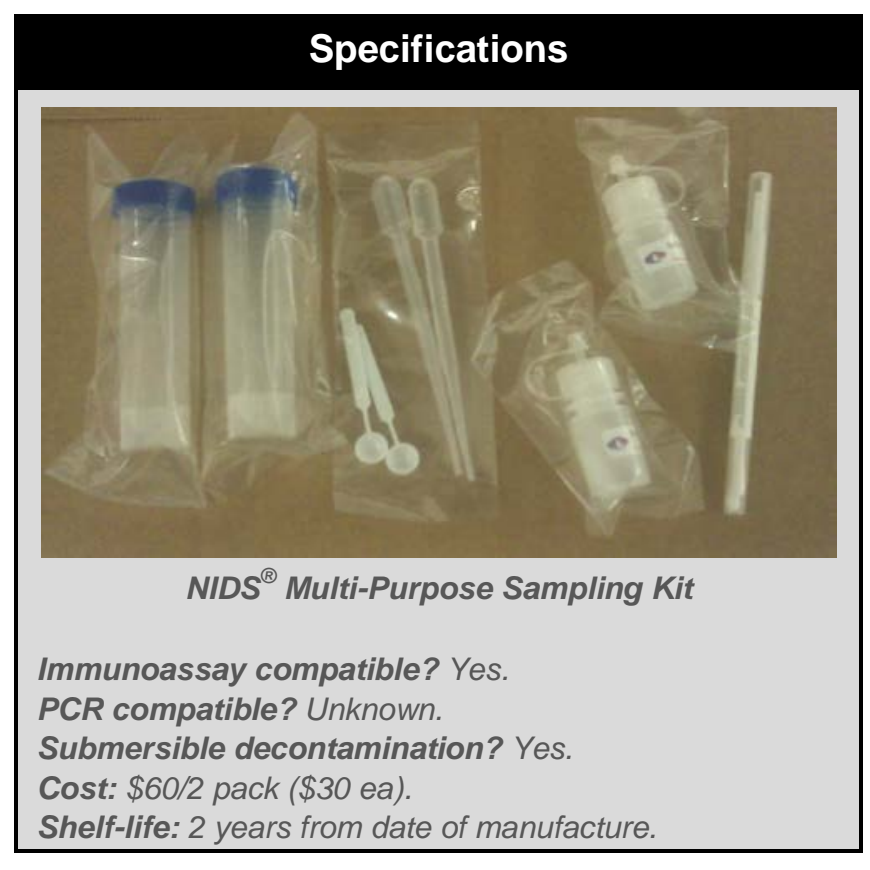
cartridges, but can be used with other manufacturer's immunoassay products.

\section{Peer-Reviewed References}

No peer-reviewed publications were found that demonstrate the use of this product for the collection of potential biothreats. 


\section{ASD Biosystems, Inc.: SCRD}

Product Link: http://www.asdbiosystems.com/p1.htm

Contact: ASD BioSystems, Inc. (info@asdbiosystems.com)

Phone: (804) 545-3102 Manufacturer's website: http://www.asdbiosystems.com

\section{Technology Summary}

The ASD Biosystems Sample Collection and Recovery Device (SCRD) is a device for collecting and transporting surface and powder-like samples, as well as recovering the swabbed sample for downstream analyses. Each tube has a unique barcode for identification. The collection device is a conical tube containing a buffer solution with a swab attached to the lid. Samples can be collected into a variety of user-specified buffers including: Tris with $1 \%$ pluronic acid, PBS, water, or PBS with $0.1 \%$ Tween-20.

To collect a sample, the pre-moistened swab is removed from the tube and either swabbed over an 11 in. by 11 in. area (for a surface with little to no visible powder) or lightly touched to a pile of visible

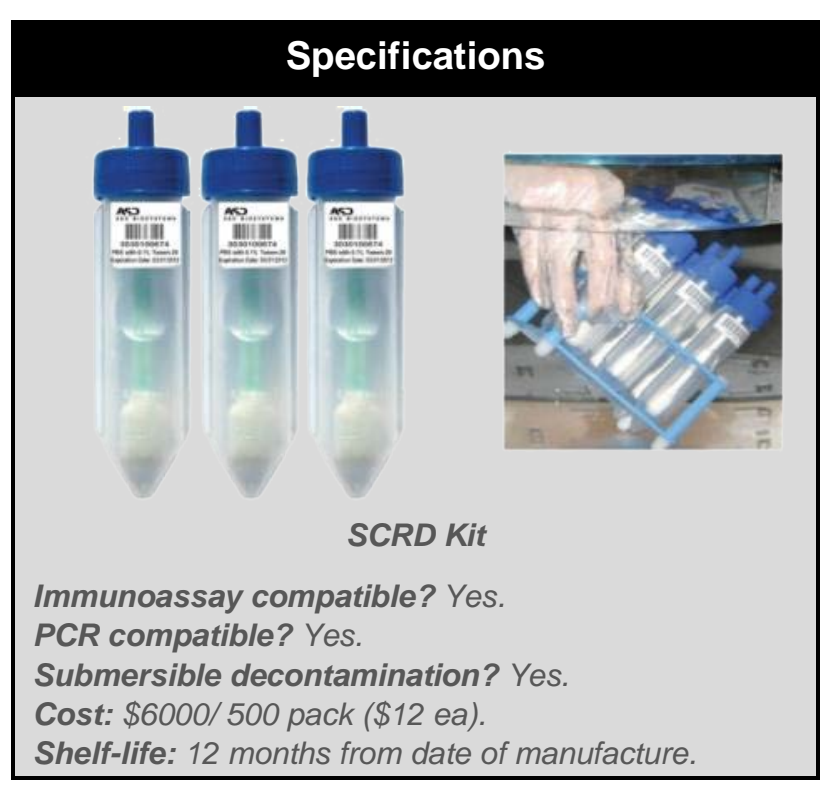
powder. The swab is then returned to the tube and the cap is secured. Once sealed, the tube can be decontaminated by dunking into a decontamination solution. To recover the sample, the tube can be squeezed manually to express the sample from the tube. The contents can also be mixed by vortexing or separated by centrifugation.

\section{Compatibility with Biodetection Assays}

These collection devices can be used with immunoassay or PCR-based systems. Most of the available standard buffers offered by the company are compatible with both immunoassay and PCR-based detection.

\section{Peer-Reviewed References}

Frawley, D. A.; Samaan, M. N.; Bull, R. L.; Robertson, J. M.; Mateczun, A. J.; Turnbull, P. C. B. Recovery Efficiencies of Anthrax Spores and Ricin from Nonporous or Nonabsorbent and Porous or Absorbent Surfaces by a Variety of Sampling Methods. J. Forensic Sci. 2008, 53, 1102-1107. DOI: 10.1111/j.1556-4029.2008.00811.x.

Two studies were conducted to determine the ability of different materials to collect biothreat agents from different surfaces. The first study is most applicable to first responder sampling needs for field biodetection. The second study focused on the retrieval efficiency of contact plates as compared to swabs. Both studies investigated porous and nonporous surfaces. Bacillus anthracis (Sterne strain) spores and purified ricin were prepared as dilute solutions, applied to surfaces, and allowed to dry before sampling (which could be a factor impacting the generally low recovery rates observed). In the first study, swab types included dry and pre-moistened polyester/Dacron ${ }^{\circledR}$ (Curtis Matheson Scientific), dry and premoistened gauze Kendall ${ }^{\circledR}$ wipes, ASD Biosystems' SCRD product and dry 3M Trace Evidence 
Collection Filters. In the second study, three different types of agar plates (pressed directly onto the surface, i.e., contact plates) were compared to pre-moistened cotton swab surface sampling. Large variations in individual swab/sample collection reflected the highly variable nature of the sampling process and the need to perform replicates when attempting to compare product performance. Average recoveries for Bacillus anthracis and ricin were highest from plastic surfaces (1-7\%) vs. untreated wood (0.3-6\%) and cotton cloth (0.6-4\%). For all surfaces, the moist gauze performed best (4-7\%) vs. the moist polyester swab (1.1-5.5\%) and SCRD (1.5-4.1\%). The recovery using dry swabs was significantly lower than moist swabs. Moist cotton swabs performed similarly to moist polyester swabs. Contact plates achieved over $30 \%$ recovery from plastic and only a few percent recovery from fabric. 


\section{New Horizons Diagnostics, Inc.: SWIPE ${ }^{\mathrm{TM}}$ Kits}

Product Link: http://www.nhdiag.com/profile_one.shtml

Contact: Larry Loomis (larryl@nhdiag.com)

Phone: (443) 543-5755 Manufacturer's website: http://www.nhdiag.com

\section{Technology Summary}

New Horizons Diagnostics (NHD) SWIPE ${ }^{\mathrm{TM}}$ kits are pre-packaged, sterilized sampling kits for the HazMat community. SWIPE ${ }^{\mathrm{TM}}$ kits are available in five different formats, all of which contain a slide-lock bag for dunkable decontamination, if necessary.

- $\mathrm{SWIPE}^{\mathrm{TM}}-1$ (\$31.50 each) is a large surface collection kit that includes $25 \mathrm{~mL}$ of proprietary buffer, an adenosine triphosphate (ATP)-free sponge, a Whirl-Pak ${ }^{\circledR}$ bag, and a slide-lock bag.

- $\mathrm{SWIPE}^{\mathrm{TM}}-2$ (\$31.50 each) is a small-surface or powder collection kit, which includes a spatula, $25 \mathrm{~mL}$ of buffer, collection tube, two swabs, and a slide-lock bag.

- $\mathrm{SWIPE}^{\mathrm{TM}}-3$ (\$17.50 each) is a liquid collection kit with two syringes, a WhirlPak $^{\circledR}$ bag, and a slide-lock bag.

- $\mathrm{SWIPE}^{\mathrm{TM}}-4$ (\$24.15 each) is an aerosol on filter collection kit containing a collection tube, $25 \mathrm{~mL}$ of buffer, forceps, and a slidelock bag.

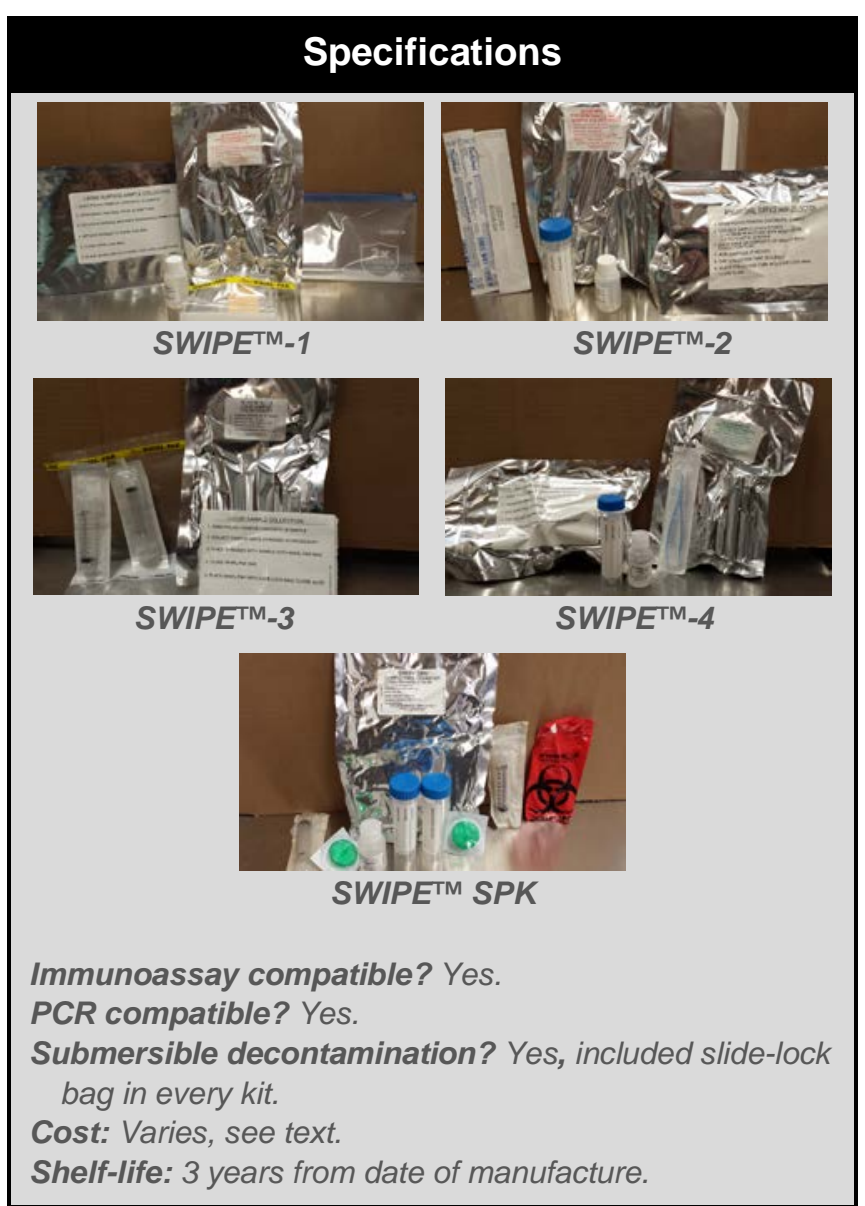

- $\mathrm{SWIPE}^{\mathrm{TM}}$ Sample Processing Kit (SPK) (\$43.50 each) is a kit designed to be used for sample dilution or pre-filtration of turbid samples and includes syringes, collection tubes, $25 \mathrm{~mL}$ of buffer, a biohazard bag for waste collection, and a slide-lock bag.

\section{Compatibility with Biodetection Assays}

These collection devices can be used with immunoassay or PCR-based detection systems.

\section{Peer-Reviewed References}

No peer-reviewed publications were found that demonstrate the use of this product for the collection of potential biothreats. 


\section{QuickSilver Analytics, Inc.: Sampling Kits}

Product Link: http://chembiokits.com

Contact: Ryan Deady (ryan.deady@qukslvr.com)

Phone: (410) 676-4300 Manufacturer's website: http://www.chembiokits.com

\section{Technology Summary}

This company specializes in sampling kits for the HazMat community. Several biological sampling kits with slightly different utility are reviewed here. All kits use PBS buffer and the sample containers can be dunked for decontamination after sample collection.

- All-in-One Sample Collection Swab (\$29.16 per 5-pack). This all-in-one sampler includes buffer, swab, and dropper. After swabbing a surface, the swab is placed back in the collection device, and the enclosed buffer compartment is snapped open to release the solution, and the device is shaken to mix the sample and buffer. The integral dropper can then be used to apply solubilized sample to detection assays that require a liquid sample (e.g., PCR or immunoassay).

- S3 ${ }^{\mathrm{TM}}$ Bio Sampler (\$26.12). This device is designed to collect biological samples from potentially contaminated surfaces onto a PBS buffer-moistened sterilized sponge for field or laboratory analysis.

- S3 ${ }^{\mathrm{TM}}$ Extension Tool (\$12.75). This reusable tool is six inches long and can extend to over 25 inches to enable sampling in hard-to-reach places. It is designed to hold a sponge in the spring clip and the chromeplated brass construction allows repeated decontamination.

- Small Area Sampling (SAS ${ }^{\mathrm{TM}}$ ) Kit (\$22.68). This kit is intended to sample small areas and includes two swabs that can be moistened with the provided buffer (4 mL of PBS) for sampling powders or used directly for liquids. The swab can be broken off into the buffer bottle and placed into the $50-\mathrm{mL}$ centrifuge tube and

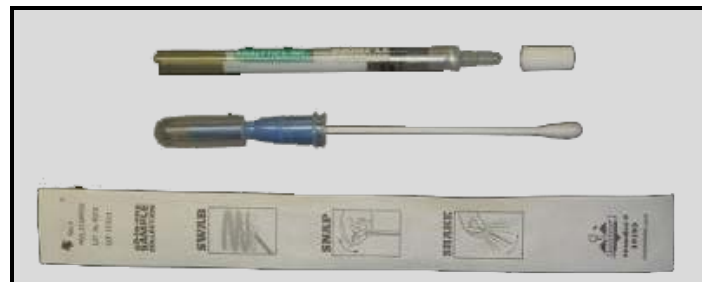

All-in-One Sample Collection Swab
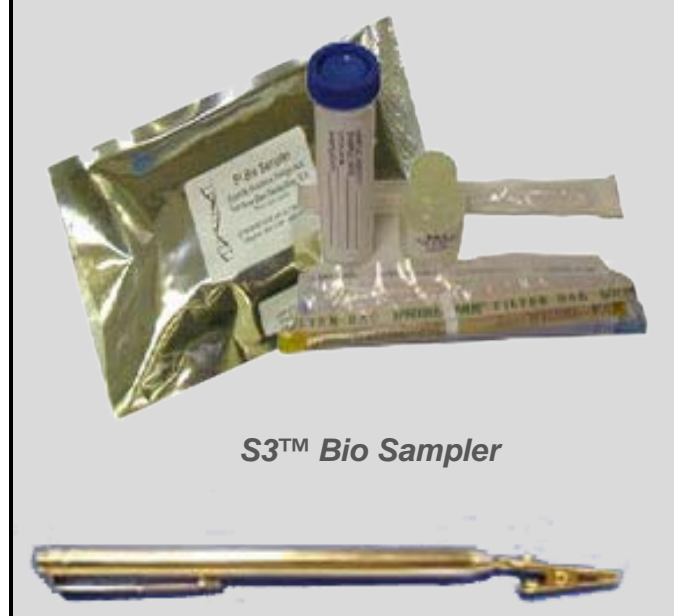

$\mathrm{S3}^{\mathrm{TM}}$ Extension Tool

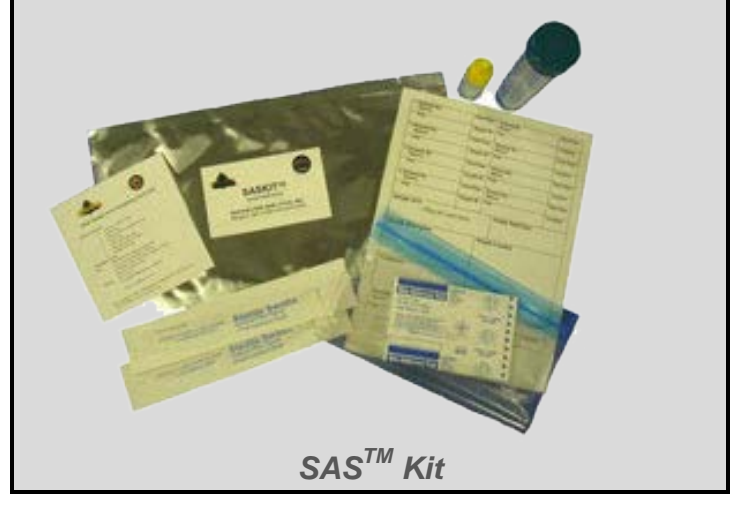
provided plastic bag for transport to a lab for analysis. A chain-of-custody form is also included. This kit has a 4-year shelf-life from the date of manufacture. 


\section{(QuickSilver Sampling Kits, Continued)}

- Mini Push Pack ${ }^{\mathrm{TM}}$ Sampling Kits. These kits are highly compact and portable single-use units that contain all the tools and supplies (i.e., sample bags, spatulas, scalpels, swabs, pipettes, vials, and parafilm) needed to take a single sample. Kits are available for a variety of samples (see below). Each type of kit is identified by a color-coded Velcro ${ }^{\circledR}$ strap that contains the package. Following the sampling procedure, the kit can also be used for waste disposal by placing all waste on the absorbent liner, rolling it up, and securing with the Velcro $^{\circledR}$ strap.

Training versions (containing uncleaned or screened/non-sterile components) of the kits are available for a discounted price (38 to 54\% less). Mini Push Pack ${ }^{\mathrm{TM}}$ Sampling kits include the following: Wipe Sampling Kit (\$62.35), Biological Sampling Kit (\$44.61), Liquid Sampling Kit (\$102.70), and Solid Sampling Kit (\$63.81).

- Biological Sampling Kit (BiSKit ${ }^{\mathrm{TM}}$ ) Large-Area Sampling Kit (\$51.65). This kit is designed to sample $1 \mathrm{~m}^{2}$ of surface for bacteria, viruses, and toxins and to solubilize the sample in PBS buffer with sufficient volume $(15 \mathrm{~mL})$ for extensive testing and archiving. The kit has been designed to be easy to use in Level A protective gear and to enable transport of a sample without leaking. The lid of the unit has a foam material attached for collecting either a wet or a dry sample. After sampling, the lid is refastened and the unit can then be removed from the area for later testing or used for immediate analysis. This kit has a 2-year shelf-life from date of manufacture. A reduced-cost training version of this kit (not cleaned or screened/non-sterile components) is also available.

- B2Cтм Bulk Sample Collection Kit (\$32.46). This kit contains sample containers, tamper tape, swabs, laminated cards, sample and biohazard waste bags, Mini Push Pack ${ }^{\mathrm{TM}}$ Kits:

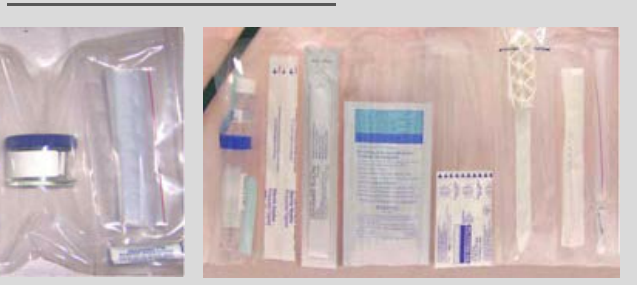

Bio Sampling Kit
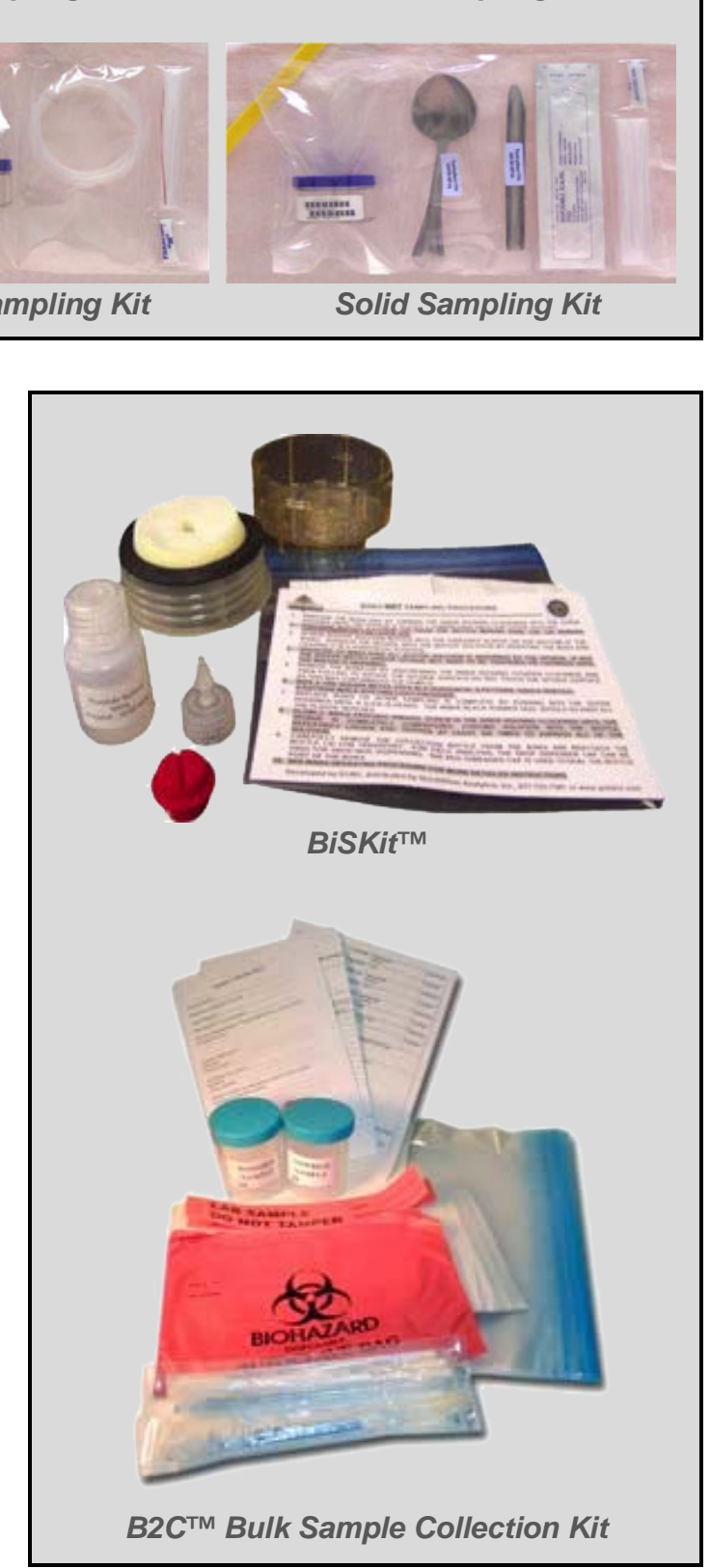

field-screening result and chain-of-custody forms, sample collection and instruction sheets, and document pouches. 


\section{(QuickSilver Sampling Kits, Continued)}

- S2Pтм Swab Sampling Powder Kit (\$7.91). This kit contains a swab, buffer solution, a sample bag, a sample collection sheet, and an instruction sheet.

- QSA Model 102 ${ }^{\mathrm{TM}}$ Full Forensic Analytical Center (FAC) (\$3050.65). This is a comprehensive sampling kit contained in a backpack for chemical, radiological, and biological agent sampling. This kit was initially developed by the Edgewood Chemical and Biological Center (ECBC) FAC Mobile Labs Team, and the kit includes enough single packaged supplies to collect nine chemical, nine biological, six radiological, and three explosive samples. Individual kit items are available for purchase. The overall weight is $32 \mathrm{lb}$ and the dimensions are 22 in. wide x 13 in. high x 11 in. diameter. A reduced-cost (22\% less) training version of this kit (not cleaned or screened/non-sterile components) is also available.

- Residue and Powder Sampling Area Kit (RAPSAK ${ }^{\mathrm{TM}}$ ) (\$434.86). This lightweight tool-box sized kit is designed for collecting residue and powder samples. The kit includes single-use tools (for collecting up to nine samples of different sizes), chain-of-custody forms, two different cameras, and a ruler. The overall weight is $8 \mathrm{lb}$ and the dimensions are 19 in. long $\mathrm{x}$ 10 in. high $x 10$ in. wide.

- Incident Response Sampling Kit (IRK ${ }^{\mathrm{TM}}$ ) (\$1321.81). This kit is designed for use by emergency responders and contains all materials necessary to collect air, liquid, and solid samples for chemical and biological analysis. Instructions and flow-charts are included that detail preparation for entry into the hot zone and sample transfer to law enforcement. The kit meets U.S. Environmental Protection Agency (EPA) cleanliness standards. Individual kit items are available for purchase. The overall weight is $34 \mathrm{lb}$ and the dimensions are 18 in. wide x 12 in. high x 24 in. diameter.

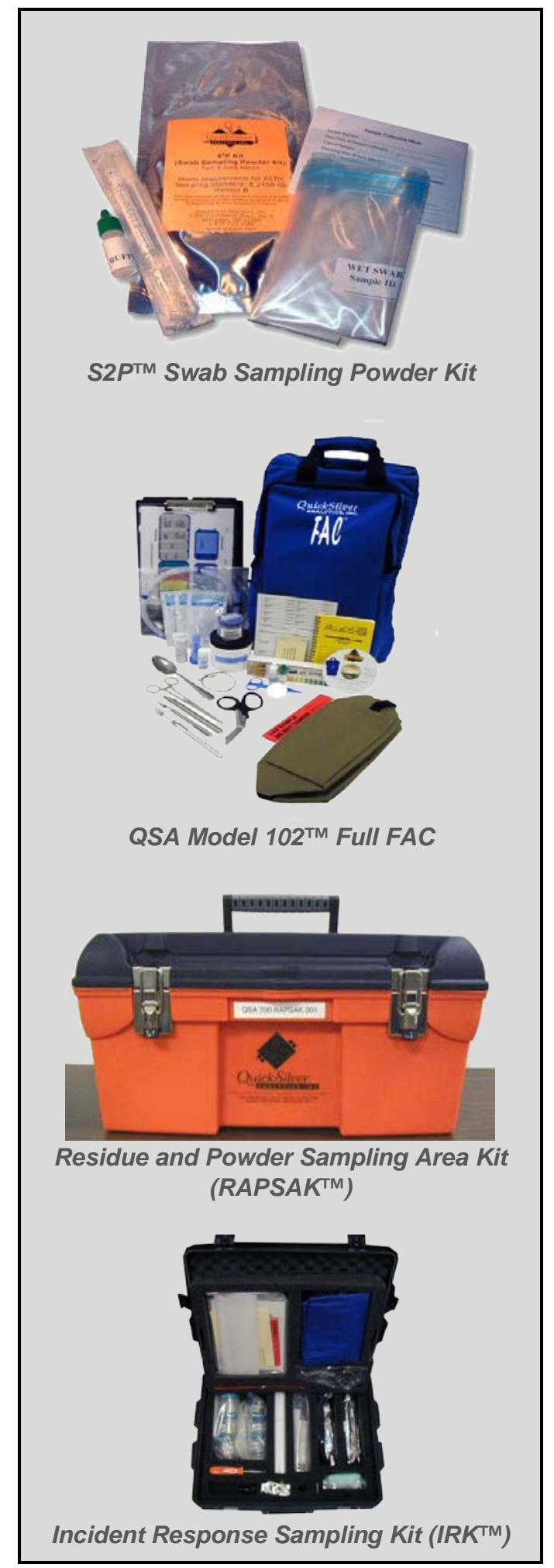


(QuickSilver Sampling Kits, Continued)

- Chemical, Biological, Radiological, and Explosive (CBRE) Transport Case Sampling Kit (\$2207.50). This sampling kit on a three-wheeled cart features a disposable cart to simplify decontamination efforts. It includes tools for sampling for over 10 chemical warfare-related compounds, toxic industrial chemicals (TICS), and toxic industrial material (TIMS) and tools for collecting biological samples. Enough individually packaged supplies are included to collect nine chemical, nine biological, six radiological, and three explosive samples. Individual kit items are available for purchase. The overall weight is $33 \mathrm{lb}$ and the dimensions are $18 \mathrm{in}$. long x 11 in. wide x 25 in. high. A reduced-cost (25\% less) training version of this kit (not cleaned or screened; non-sterile components) is also available.

- CBRE Hard Case Sampling Kit (\$3398.99). This kit’s components are housed in foam-lined compartments in a rugged case. The kit includes tools for sampling for over 10 chemical warfare-related compounds, TICS, and TIMS, as well as tools for collecting biological samples. Enough individually packaged supplies are included to collect 9 chemical, 13 biological, 6 radiological, and 3 explosive samples. Individual kit items are available for purchase. The overall weight is $48 \mathrm{lb}$ and the dimensions are 31 in. long x 20 in. wide x 12 in. high. A reducedcost (13\% less) training version of this kit (not cleaned or screened; non-sterile components) is also available.

The management system governing the manufacture of these products is ISO 9001:2008-certified (specifies the requirements of a quality management system).

\section{Compatibility with Biodetection Assays}

Kits that use a PBS buffer for solubilizing collected samples are generally compatible with both PCR-based detection systems and immunoassays. Check with the manufacturer for current specifications.

\section{Peer-Reviewed References}

Buttner, M. P.; Cruz, P.; Stetzenbach, L. D.; Klima-Comba, A. K.; Stevens, V. L.; Emanuel, P. A. Evaluation of the Biological Sampling Kit (BiSKit) for Large-Area Surface Sampling. Appl. Environ. Microbiol. 2004, 70, 7040-7045. DOI: 10.1128/AEM.70.12.7040-7045.2004.

The BiSKit was evaluated and compared to two other sampling approaches. Bacillus atrophaeus spores were used as a simulant for Bacillus anthracis and deposited from an aerosol onto wood laminate and metal surfaces. Manufacturer guidance regarding the sampling area was followed for BiSKit $\left(1 \mathrm{~m}^{2}\right)$, 
Critical Reagents Program cotton swab sampling kit (100 $\mathrm{cm}^{2}$ sampling area), and ASD’s foam swab sample processing kit $\left(317 \mathrm{~cm}^{2}\right)$. Culturing, quantitative PCR and immunoassays were used for analysis, and the results were compared based on the total number of spores collected and spores collected per unit area sampled. The BiSKit collected less spores per unit area than the swabs, but collected more spores per sample due to the larger area sampled. In general, spore recovery was greater from metal surfaces than from wood laminate surfaces. The BiSKit was evaluated for both wet and dry sampling. It was noted that delaying solubilization of a sample will improve its stability for later analysis. 


\section{Smiths Detection, Inc.: ClearSampler ${ }^{\mathrm{TM}}$}

Product Link: http://www.youtube.com/watch?v=GuByche3FAA

Contact: Mitch Friedman (mitch.friedman@smithsdetection.com)

Phone: (203) 207-9733 Manufacturer's website: http://www.smithsdetection.com

\section{Technology Summary}

The ClearSampler ${ }^{\mathrm{TM}}$ is designed to work with Smiths Detection HazMatID ${ }^{\mathrm{TM}}$ and HazMatID ${ }^{\mathrm{TM}}$ Elite Fourier Transform Infrared (FTIR) instruments. It can be used to sample liquids, thin films, or small quantities of sample and is placed directly on the integrated solid press on the FTIR with no additional sample preparation required.

The disposable sampling discs have no FTIR absorption profile, so they do not cause any potential spectral interference like other sampling swabs can. The handle is reusable and the discs can be separated from the handle and saved for additional analyses, archived, decontaminated or disposed.

The management system governing the manufacture of this product is ISO 9001:2008-certified (specifies the requirements of a quality management system).

\section{Compatibility with Biodetection Assays}

The ClearSampler ${ }^{\mathrm{TM}}$ sampling disc is constructed of fine metal-mesh wire that is coated with a proprietary material. While this sampler is specifically designed to be used in Smiths Detection FTIR instruments, it is compatible with other FTIR solid presses as long as there are no obstructions. It is unknown if the sampling disc material is compatible with extraction and detection approaches such as immunoassay or PCR-based detection.

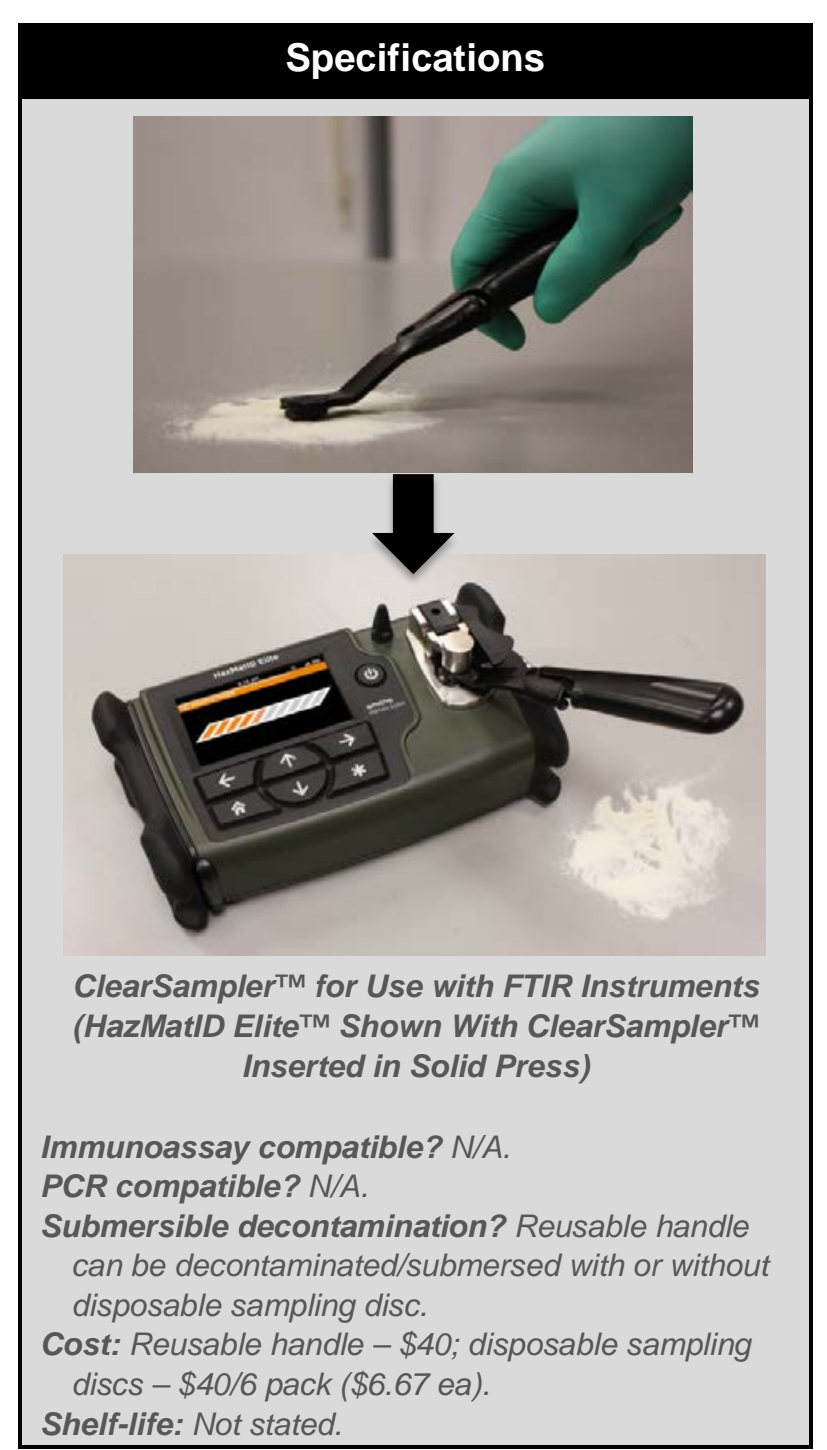

\section{Peer-Reviewed References}

No peer-reviewed publications were found that demonstrate the use of this product for the collection of potential biothreats. 


\section{Tetracore, Inc.: BioThreat Alert ${ }^{\circledR}$ Sample Collection Kit}

Product Link: http://tetracore.com/bio-warfare/index.html

Contact: Ashley Bottomly (abottomly@tetracore.com)

Phone: (240) 268-5400 Manufacturer's website: http://www.tetracore.com

\section{Technology Summary}

The BioThreat Alert ${ }^{\circledR}$ sampling kit contains tools and supplies for collecting 25 samples.

\section{Compatibility with Biodetection Assays}

The sample collection kit was designed for use with Tetracore's BioThreat Alert ${ }^{\circledR}$ Lateral Flow Assay (LFA), but could be used with other manufacturer immunoassays. It is not designed for use with PCR.

The kit is designed for the collection of up to 25 samples and includes 25 swabs, 25 sample vials, 25 alcohol pads, 3 bottles of sample buffer (12 mL each), 5 scoops, 3 scissors, 3 tweezers, 1 permanent marker, and instructions for use.

\section{Peer-Reviewed References}

No peer-reviewed publications were found that demonstrate the use of this product for the collection of potential biothreats.

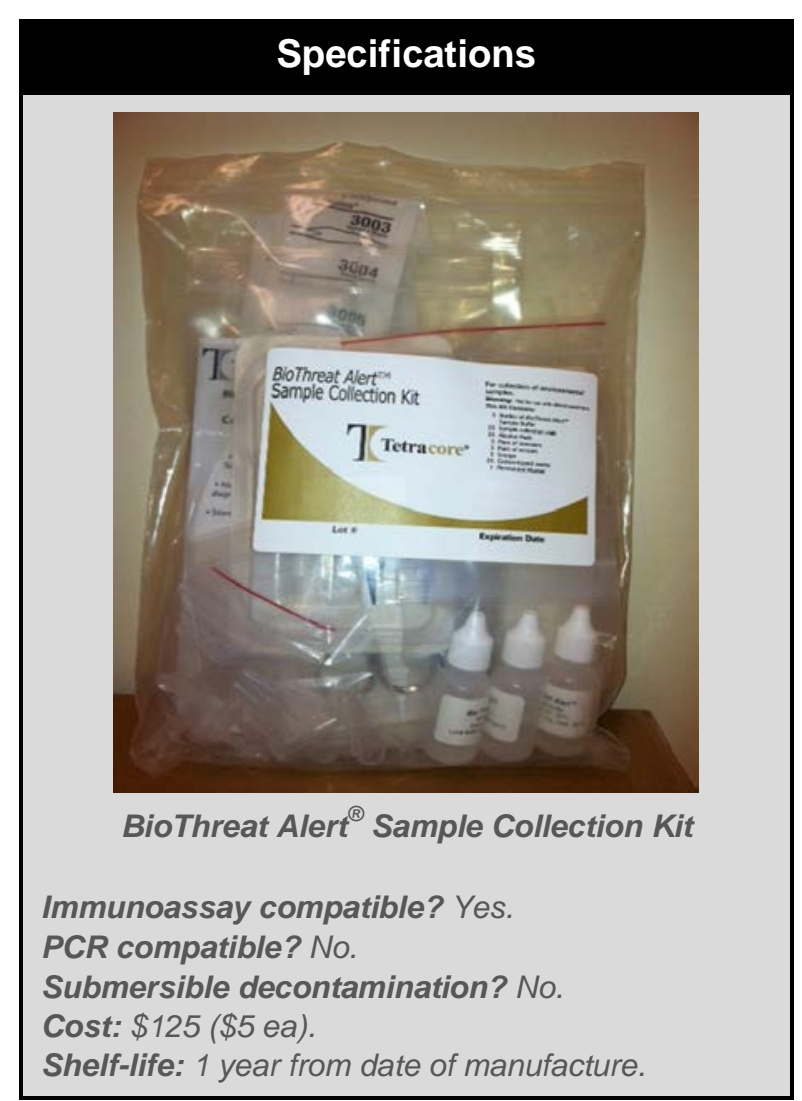




\section{Tetracore, Inc.: Field Kit for T-COR $4^{\mathrm{TM}}$}

Product Link: http://tetracore.com/bio-warfare/index.html

Contact: Ashley Bottomly (abottomly@tetracore.com)

Phone: (240) 268-5400 Manufacturer's website: http://www.tetracore.com

\section{Technology Summary}

The Field Kit for T-COR 4 ${ }^{\mathrm{TM}}$ Real-Time PCR Assays contains tools and supplies for collecting 64 samples in the field.

\section{Compatibility with Biodetection Assays}

The Field Kit was designed for use with Tetracore's T-COR $4^{\mathrm{TM}}$ real-time PCR assays, but could be used with other manufacturer PCR assays. It is not designed for use with immunoassays.

This sampling kit is designed for the collection of up to 64 samples and includes 64 swabs, 64 bleach wipes, 64 bottles of buffer solution, 128 small transfer pipettes, and 2 large transfer pipettes.

\section{Peer-Reviewed References}

No peer-reviewed publications were found that demonstrate the use of this product for the collection of potential biothreats.

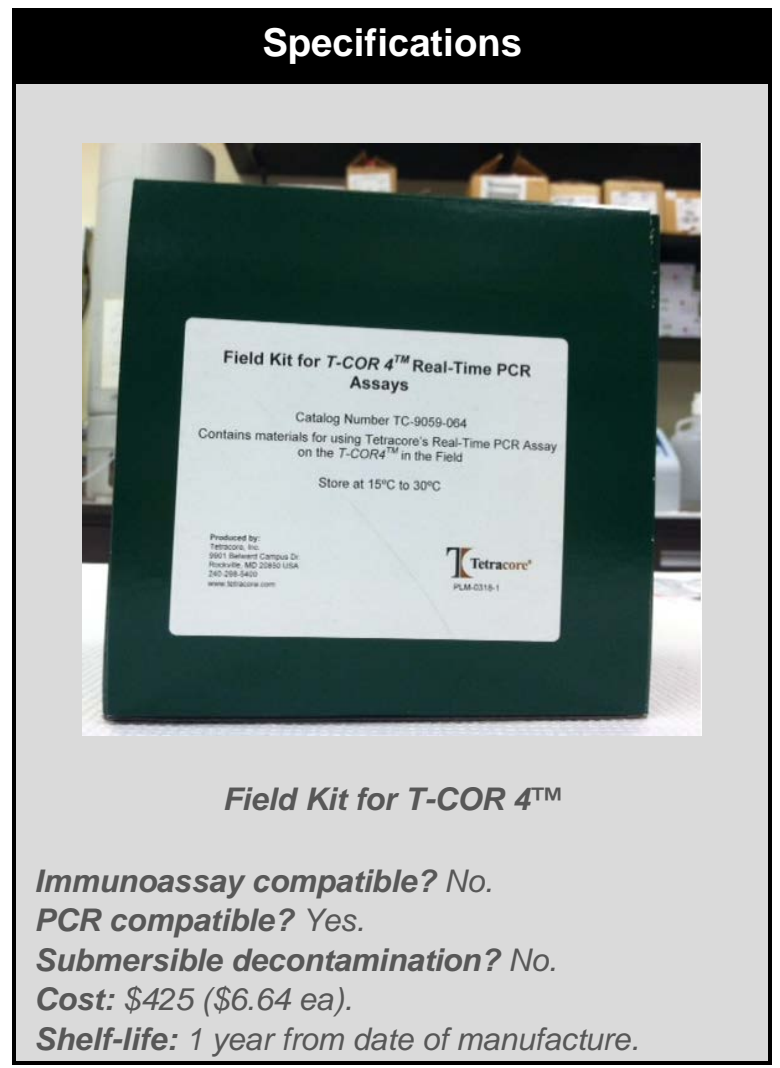




\subsection{General Biological Indicator Tests}

The principle of a biological indicator technology is to simply detect the presence of biological material in a sample. Typically, these tests detect the presence of proteins, deoxyribonucleic acid (DNA)/ribonucleic acid (RNA), or adenosine triphosphate (ATP). Proteins and DNA are found in all cells, including skin cells, spores and bacterial cells. ATP is a metabolite found only in living cells. Biological toxins (e.g., ricin and botulinum toxins) are typically protein-based, but toxin samples can also contain DNA if the material is crudely prepared from the cells that produced the toxin. For example, the presence of botulinum or ricin toxins is indicated by the presence of DNA from Clostridium botulinum and Ricinus communis, respectively.

In addition to biological indicator assays that detect proteins, DNA/RNA, and ATP, FTIR spectroscopy can be used to indicate the potential presence of biological materials in a sample. FTIR is a common analytical tool used by first responders that provides information about sample composition by matching the spectral fingerprint of the sample to a library containing spectral fingerprints for thousands of compounds. If a sample's spectrum is not in the library, the instrument software algorithm will attempt to identify it based on chemicals that are in the library and that have similar spectral features. A "score" is assigned and displayed to the user for potentially matching chemicals in the library, and typically ranges from 0 (no match) to 1 (a perfect match). The score does not represent relative concentration and does not represent probability of correct identification. However, scores $>0.9$ often, but not always, indicate that the sample is similar to the substance indicated by the library match. Some FTIR spectrometers include spectral analysis algorithms to indicate that a sample may be of biological origin based on the presence of protein. It should be noted that FTIR has not been extensively validated for detection of biological material in powders and is primarily used as a screening tool to help identify chemical substances.

While biological indicator tests are relatively rapid and inexpensive, they should be used as a screening tool in conjunction with more specific tests. In general, biological indicator tests have low specificity (i.e., may result in a false-positive result) and low sensitivity (i.e., may result in a falsenegative result), although the ATP test does have a reported limit of detection (LOD) several orders of magnitude lower than immunoassays. General biological screening tests detect a broad range of biological and organic materials, but do not confirm the presence of a specific biothreat agent.

\section{Protein Test}

- Detects any type of protein (including milk proteins in coffee creamer and powdered infant formula)

- Protein tests may also include a pH test (biological material is typically neutral in $\mathrm{pH}$ ) or a starch test (indicative of a food ingredient)

- Easy to use (add or swab sample, mix, and visually read; or simply swab and read for all-in-one test)

- Operator manually reads color change for protein and $\mathrm{pH}$ or starch

- Sample to answer in 5 minutes or less

- LOD: 10 to 100 million Bacillus anthracis spores (equivalent to about 1000 to 10,000 infectious doses, but still a barely visible amount of powder, $<1 \mathrm{mg}$ )

- Typical assay cost: assays come packaged in various quantities and costs range from \$2 to \$28 each.

- Typical shelf-life: 14-24 months 
- Examples:

- BioCheck $^{\circledR}(20 / 20$ Gene Systems)

- INDIPRO (Macherey-Nagel)

- TASKit BioScreener ${ }^{\mathrm{TM}}$ (Field Forensics)

\section{FTIR Spectroscopy}

- Primarily used to rapidly identify chemical composition of an unknown sample

- Proteins (contained in most biological materials) give a unique FTIR spectrum and should be detected in samples if they have a protein content of at least $10 \%$

- FTIR has not been extensively tested as a screening tool for biological material in suspicious powders

- Identification of sample composition is based on comparison of the sample's composite spectrum to a library of known individual component spectra

- Moderate ease-of-use

- Mixtures can be difficult for software algorithms to correctly identify individual substances

- Sample to answer in $<5$ minutes

- LOD: $10 \%$ protein content in sample (no studies have been performed to determine the sensitivity in terms of number of spores)

- High instrument and upgrade costs such as additional library spectra (\$1200 to $\$ 17,000)$

- No consumables (no per test cost)

- Examples:

- HazMatID ${ }^{\text {TM }} 360$ (Smiths Detection)

- HazMatID ${ }^{\text {TM }}$ Elite (Smiths Detection)

- HazMatID Ranger ${ }^{\mathrm{TM}}$ (Smiths Detection)

- $\quad$ TruDefender ${ }^{\mathrm{TM}}$ (Thermo Scientific)

\section{DNA Test}

- Detects any type of DNA (e.g., human, plant, or animal) and some types of RNA

- Easy to use (add sample, mix, and read)

- Requires a fluorescence optical reader

- Sample to answer in about 5 minutes

- LOD: 1 to 10 billion Bacillus anthracis spores (equivalent to about 1 to 10 million infectious doses and a readily visible amount of powder, approximately 1 to $10 \mathrm{mg}$ )

- Instrument cost (fluorometer): \$12,000

- Typical assay cost: \$70 (for microbial screen)

- Typical shelf-life: 12 months

- Example: Prime Alert ${ }^{\circledR}\left(\right.$ GenPrime $\left.^{\circledR}\right)$ 


\section{ATP Test}

- Tests if any type of cellular material is present and alive

- Moderate ease-of-use (involves several steps including pipetting and filtering steps)

- Note: for spores an additional step ( 15 minutes) must be performed prior to detection to stimulate the spore to convert to a vegetative (live cellular) state to enable detection

- Requires an optical reader

- Sample to answer in about 20 minutes

- LOD: 10,000 Bacillus anthracis spores (approximately one infectious dose; amount not visible by eye)

- Instrument cost (optical reader): $\$ 3000$ to $\$ 5000$

- Typical assay cost: $\sim \$ 3$ to $\$ 5$

- Shelf-life: 12 months (temperature dependent)

- Examples:

- $\quad$ PROFILE $^{\circledR} 1$ (New Horizons Diagnostics)

- Clean-Trace $^{\mathrm{TM}}(3 \mathrm{M})$

In the remainder of this section we have grouped together the general biological indicator tests based on the type of analysis they perform: protein tests (including FTIR), DNA tests and ATP tests. 


\section{0/20 Gene Systems, Inc.: BioCheck ${ }^{\circledR}$ Powder Screening Kit (Protein Test + pH Test)}

Product Link: http://biocheckinfo.com/test-kit

Contact: Barry Cohen (sales@2020gene.com)

Phone: (240) 453-6339 (Ext. 103) Manufacturer's website: http://biocheckinfo.com

\section{Technology Summary}

The BioCheck ${ }^{\circledR}$ Powder Screening Kit is a tool to screen for biological material in visible powder samples. The test is not designed for environmental sampling (e.g., soil). A sample is collected with the provided swab, added to a liquid-containing tube, and allowed to incubate for 5 minutes. If the sample contains sufficient protein, the solution in the tube turns purple. If the protein assay is negative, the results are validated by inserting the provided control swab into the protein test tube. If the assay is working correctly, this swab should turn the solution purple. A positive protein result is a tentative indication of the presence of a biological agent or toxin. The $\mathrm{pH}$ test will turn pink/red if the sample is acidic, blue if the sample is basic, and have no color change or turn slightly yellow if the sample is neutral. The $\mathrm{pH}$ of biological samples is typically neutral. Samples with an acidic $\mathrm{pH}$ may cause the protein test to fail. If a BioCheck $^{\circledR}$ test is positive, additional tests should be performed to determine if a biological agent of concern may be present or if the sample merely contains a harmless proteincontaining substance (e.g., brewer's yeast or powdered milk). This kit is also distributed by numerous other companies including Alexeter Technologies, Fisher Scientific, Haz Tech Systems, Laurus Systems, Safety Solutions, and Smiths Detection.

This product has received a "Designated" classification (proven effectiveness, with confidence of repeatability) by DHS as part of its Support Anti-terrorism by Fostering Effective Technologies (SAFETY) Act of 2002 (www.safetyact.gov).

\section{Peer-Reviewed References}

Poore, C.; Clark, P.; Emanuel, P. A. An Evaluation of Suspicious Powder Screening Tools for First Responders. J. Hazard. Mater. 2009, 172, 559-65. DOI: 10.1016/j.jhazmat.2009.05.142. 
This study compared the effectiveness of three general biological indicator tests to differentiate suspicious powders from biological threat agents. Test samples included Bacillus anthracis (Sterne strain) (washed 2 or 4 times to impact extraneous DNA and cellular protein on spore surfaces), Yersinia pestis (A1122 strain), and purified ricin. Note that these studies were performed with biothreat samples added directly to the kit solutions; thus, LODs are not reported as substance per milliliter (i.e., concentration). The 20/20 Gene Systems BioCheck ${ }^{\circledR}$ Powder Screening kit (protein test) could detect $1 \times 10^{8}$ colonyforming units (CFU) of Bacillus anthracis (4X wash), $1 \times 10^{7}$ CFU of Bacillus anthracis ( $2 \mathrm{X}$ wash), $1 \times 10^{7}$ CFU of Yersinia pestis, and $100 \mu \mathrm{g}$ of ricin. The GenPrime Prime Alert ${ }^{\circledR}$ (DNA test) could detect $2 \times 10^{10}$ CFU of Bacillus anthracis ( $4 \mathrm{X}$ wash), $1 \times 10^{9} \mathrm{CFU}$ of Bacillus anthracis ( $2 \mathrm{X}$ wash), and $1 \times 10^{8} \mathrm{CFU}$ of Yersinia pestis. The New Horizons Diagnostics PROFILE ${ }^{\circledR} 1$ (ATP test) could detect $1 \times 10^{4}$ CFU of Bacillus anthracis (both $2 \mathrm{X}$ and $4 \mathrm{X}$ wash) and $1 \times 10^{6} \mathrm{CFU}$ of Yersinia pestis. Because purified ricin was used the Prime Alert ${ }^{\circledR}$ and PROFILE ${ }^{\circledR} 1$ were unable to detect ricin since neither DNA nor ATP was present from residual castor beans. Some of the 16 powders tested impacted sensitivity of the tests. In general, all kits gave positive results for powders that contained the targeted substance (e.g., protein or cells), but some powders caused interferences and impacted sensitivity as discussed in the Conclusions section. 


\section{Field Forensics, Inc.: TASKit BioScreener ${ }^{\mathrm{TM}}$ (Protein Test + Starch Test)}

Product Link: http://www.fieldforensics.com/taskit-bioscreeners.html

Contact: Kevin P. Cresswell (kcresswell@fieldforensics.com)

Phone: (727) 490-3609 (Ext. 105) Manufacturer's website: http://www.fieldforensics.com

\section{Technology Summary}

The Threat Agent Screening Kit (TASKit) BioScreener $^{\mathrm{TM}}$ includes two easy-to-use tests for rapidly screening suspicious powders for the presence of biological agents. The first colorimetric test indicates if protein is present. A positive protein result suggests a biological agent or toxin may be present in the sample. If the protein test is positive, additional tests should be performed to determine if a biological agent of concern is actually present or if the sample merely contains a harmless proteincontaining substance. The second colorimetric test indicates if starch is present, which may indicate that the sample is a harmless substance (e.g., a food product). However, additional confirmatory tests are needed to rule out if a biological agent is also present.

The BioScreener ${ }^{\mathrm{TM}}$ test is primarily marketed for homeland security applications and first responders. Both the protein and starch tests can be completed in $<1$ minute. The swab and reagents are conveniently packaged in a single disposable tube.

\section{Peer-Reviewed References}

No peer-reviewed publications were found that demonstrate the use of this product for the detection of biothreat agents.

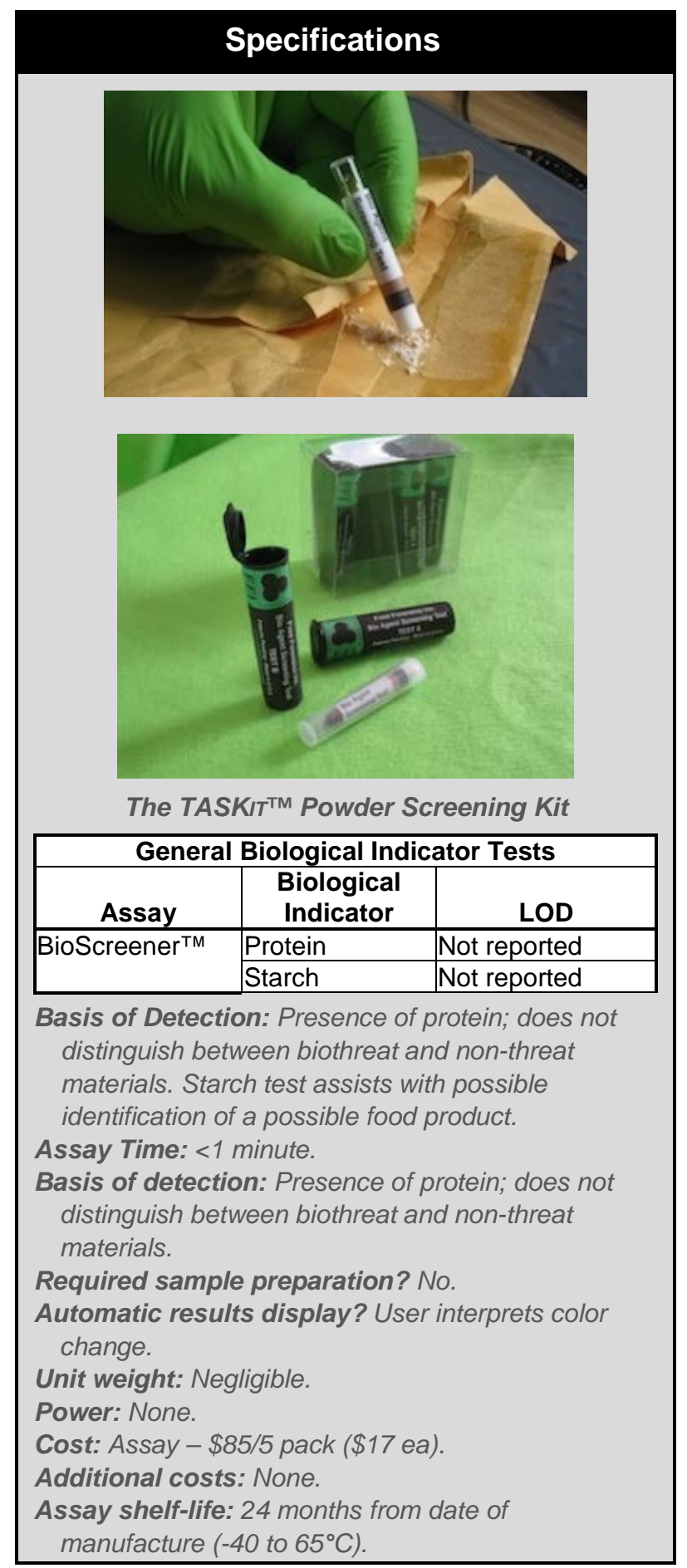




\section{Macherey-Nagel, Inc.: INDIPRO (Protein Test)}

Product Link: http://www.ctlscientific.com/cgi/display.cgi?item_num=90765

Contact: Henry Medollo (Exclusive U.S. distributor: CTL Scientific Supply Group; hmedollo@ctlscientific.com)

Phone: (631) 242-4249 Manufacturer's website: http://www.mn-net.com

\section{Technology Summary}

Like the BioCheck ${ }^{\circledR}$ Kit, this kit detects the presence of protein. The standard protocol for use is to first moisten the test strip with one drop of solution "INDIPRO-1" and then wipe the test strip over the test surface. Next, the strip is developed by applying a drop of "INDIPRO-2" solution directly to the strip. A color change (yellow to green) indicates the presence of protein.

The INDIPRO kit is primarily marketed to the food and restaurant industries for detecting protein contamination on work surfaces and utensils. However, being an assay for generic proteins, this test can also be used in a manner similar to the 20/20 BioCheck $^{\circledR}$ assay to determine if a suspicious powder contains protein.

The management system governing the manufacture of this product is ISO 9001:2008-certified (specifies the requirements of a quality management system).

\section{Peer-Reviewed References}

No peer-reviewed publications were found that demonstrate the use of this product for the detection of biothreat agents.

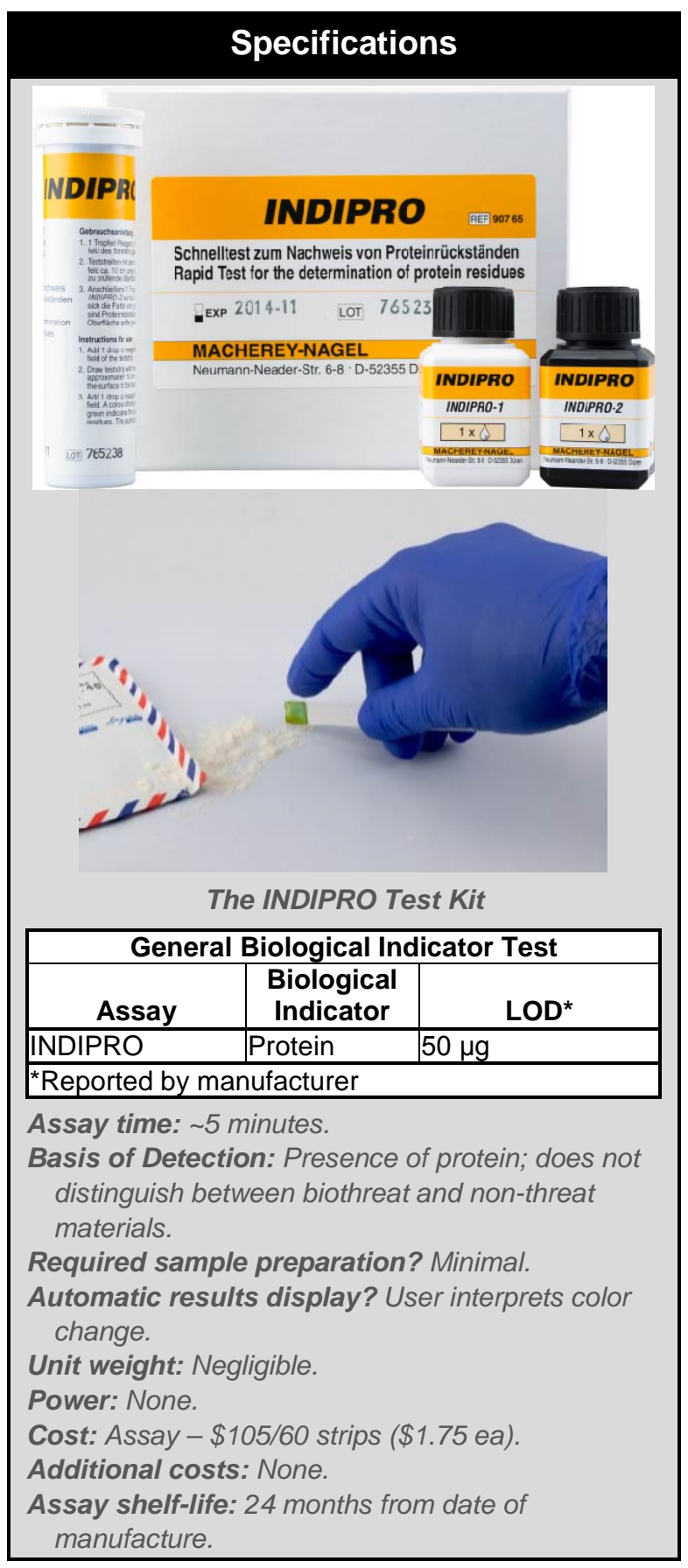




\section{Smiths Detection: HazMatID ${ }^{\mathrm{TM}} 360$ (FTIR)}

Product Link: http://www.smithsdetection.com/hazmatid360.php

Contact: Chris Lins (chris.lins@smithsdetection.com)

Phone: (770) 664-8723 Manufacturer's website: http://www.smithsdetection.com

\section{Technology Summary}

The HazMatID ${ }^{\mathrm{TM}} 360$ is a hand-portable FTIR spectrometer for the identification of unknown solids, liquids, pastes, or gels. The device includes an integrated press to ensure high-quality data collection of solid samples and an integrated well for liquid samples. A finger or stylus can be used to control the system via a touchscreen. The software provides enhanced mixture analysis and classification tools and PEAC ${ }^{\circledR}$ decisionsupport software provides detailed information regarding the management of hazardous chemicals. The HazMatID $^{\text {TM }} 360$ can identify over 32,000 substances, including many white powders and can be upgraded with the purchase of additional libraries. The system can operate in temperatures ranging from 19 to $122^{\circ} \mathrm{F}$ and in any level of humidity. A removable, rechargeable battery provides 2 hours of operation and recharges in 3 hours. The device can also use AC or automobile power. Data can be stored on removable USB, flash, floppy, or CD drives. The system is mouse and keyboard compatible and runs a Windows ${ }^{\circledR}$-based operating system. Available options include: ExtractIR (a system for removing chemicals from aqueous solutions for improved identification), wireless Bluetooth capability, additional spectral libraries, and a software upgrade.

Biological materials are tentatively identified, primarily based on their protein content and the software alerts the user when a sample has a protein content of approximately $10 \%$ or more, indicating a sample of potential biological origin.

The management system governing the manufacture of this product is ISO 9001:2008-certified (specifies the requirements of a quality management system).

\section{Peer-Reviewed References}

No peer-reviewed publications were found that demonstrate the use of this product for the detection of biothreat agents.

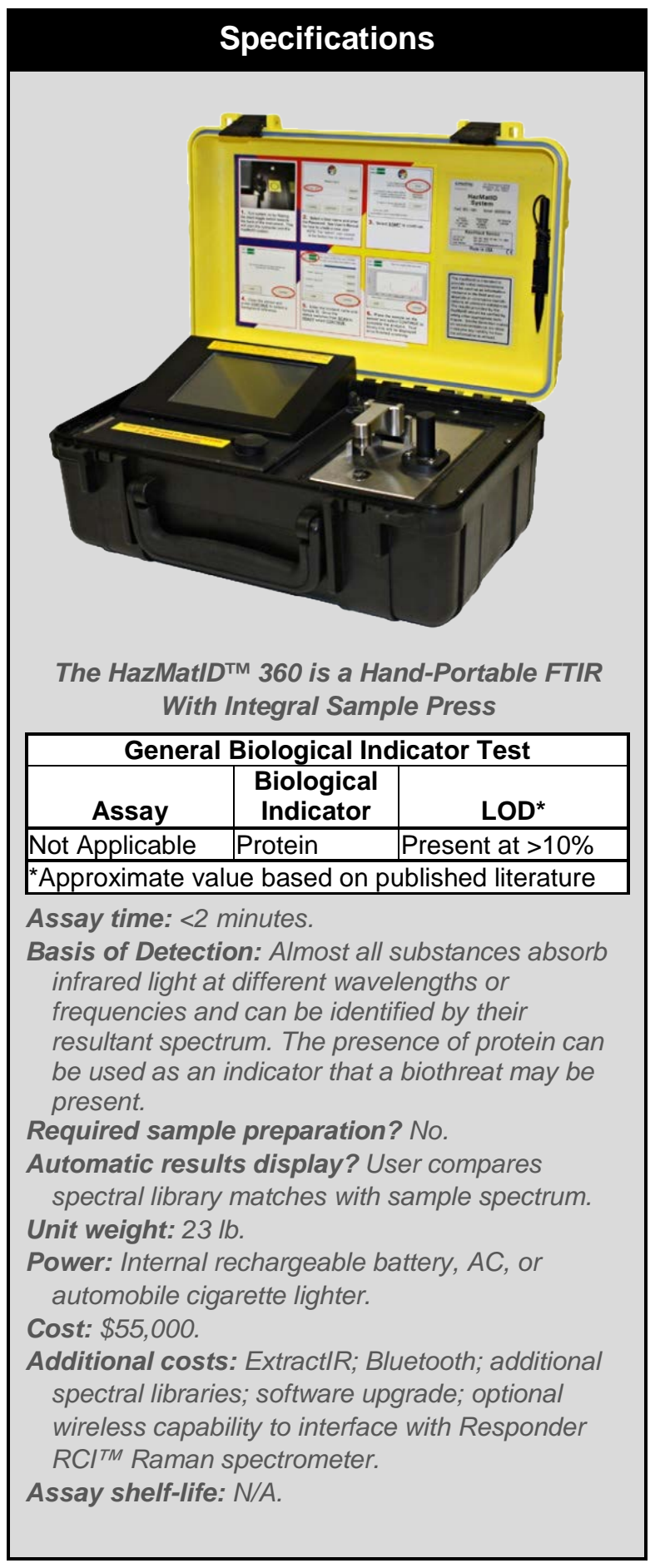




\section{Smiths Detection: HazMatID ${ }^{\mathrm{TM}}$ Elite (FTIR)}

Product Link: http://www.smithsdetection.com/HazMatIDElite.php

Contact: Chris Lins (chris.lins@smithsdetection.com)

Phone: (770) 664-8723 Manufacturer's website: http://www.smithsdetection.com

\section{Technology Summary}

The HazMatID ${ }^{\mathrm{TM}}$ Elite FTIR is specifically designed for ease-of-use in the hot zone and extreme environments. The device includes an integrated press to ensure high-quality data collection on solid samples and an integrated well for liquid samples. A second, optional, touch-to-sample diamond attenuated total reflection (ATR) sensor is available for analysis of pooled liquid and surface films and to enable robotics applications. The 4.3-in. color display has high visibility in direct sunlight. Easy-to-use software and on-screen instructional graphics guide the user through operations. Automated mixture analysis software is claimed to simplify complex sample analysis. The device is designed to military standards (MIL-STD-810G) and can operate in temperatures ranging from -4 to $122^{\circ} \mathrm{F}$ and any level of humidity. The Elite is also minimally affected by vibrations and movement during sample acquisition. An embedded radio frequency (RF) modem enables line-of-sight communication of up to $1 \mathrm{~km}$ for data transfer and remote operation with an optional repeater to extend the range. A global positioning system (GPS) is also included. The device base library includes 10,000 known spectra and user-defined libraries can be transferred from the HazMatID $^{\text {TM }} 360$ hand-portable unit. Using a command PC, an optional software package allows data management and spectral reprocessing against an upgraded library of 35,000 spectra.

Biological materials are tentatively identified, primarily based on their protein content and the software alerts the user when a sample has a protein content of approximately $10 \%$ or more, indicating a sample of potential biological origin.

The management system governing the manufacture of this product is ISO 9001:2008-certified (specifies the requirements of a quality management system).

\section{Peer-Reviewed References}

No peer-reviewed publications were found that demonstrate the use of this product for the detection of biothreat agents.

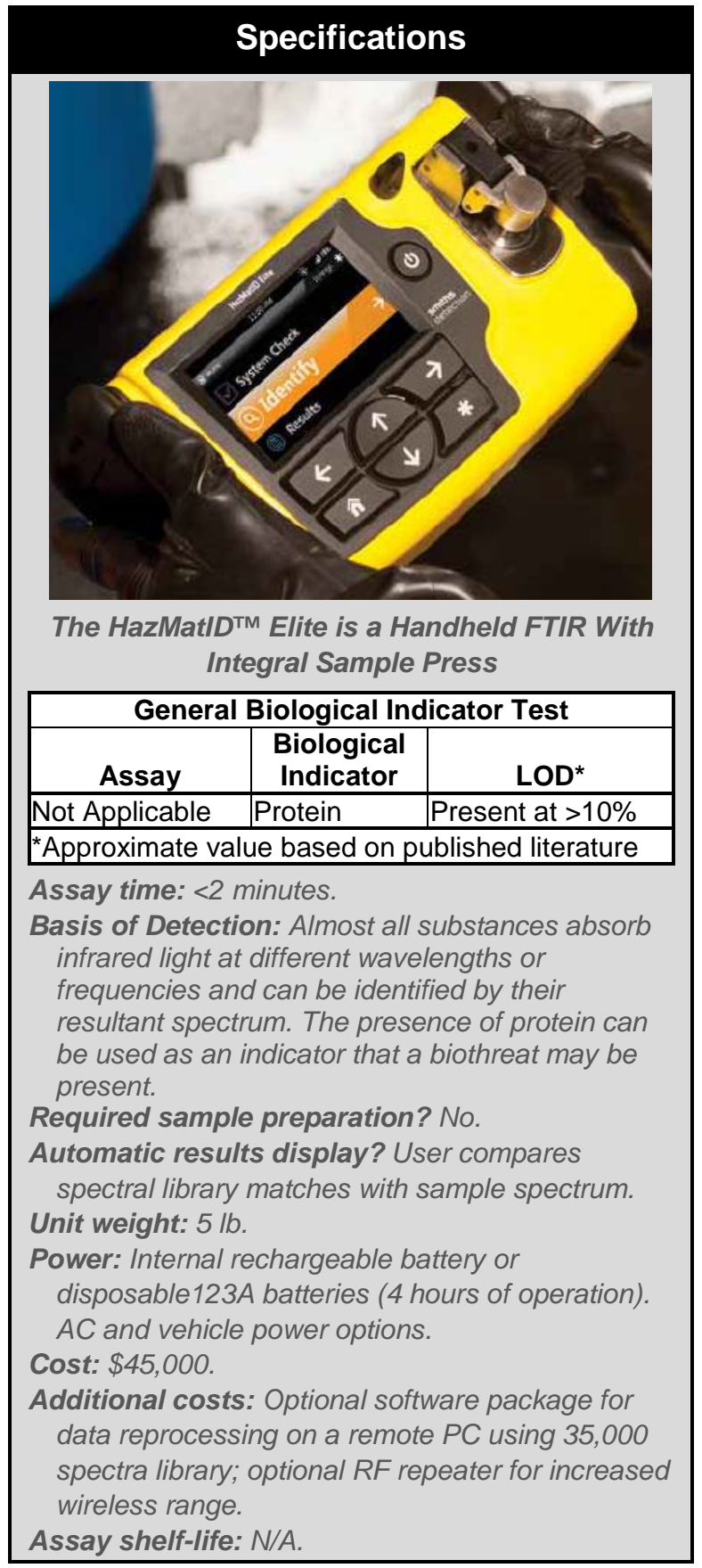




\section{Smiths Detection: HazMatID ${ }^{\mathrm{TM}}$ Ranger (FTIR)}

Product Link: http://www.smithsdetection.com/hazmatid_ranger.php

Contact: Chris Lins (chris.lins@smithsdetection.com)

Phone: (770) 664-8723 Manufacturer's website: http://www.smithsdetection.com

\section{Technology Summary}

The HazMatID ${ }^{\mathrm{TM}}$ Ranger is a FTIR designed for handheld, backpack, or robot portability and ease-of-use. Samples are measured by firmly pressing the diamond ATR sensor head directly onto a liquid or solid sample. Spectral results and a list of probable substances are displayed on the attached touchscreen personal digital assistant (PDA). The ruggedized device, but not the PDA, can be decontaminated via dunking in a decontamination solution and can withstand 40G of shock. The instrument can operate in any level of humidity and at temperatures from 19 to $122^{\circ} \mathrm{F}$. The system battery runs for about 3 hours and the PDA battery operates for about 8 hours. The standard library contains spectra of approximately 4400 materials, and the optional library contains spectra of approximately 32,000 materials. Another additional option is wireless capability that allows communication with a PC for advanced combined analysis with the Responder RCITM portable Raman spectrometer. In addition, for difficult samples (i.e., small sample amounts or samples located on irregular surfaces), the PDA can be removed and the sample placed on an optional solids press accessory for measurement.

Biological materials are tentatively identified, primarily based on their protein content and the software alerts the user when a sample has a protein content of approximately $10 \%$ or more, indicating a sample of potential biological origin.

The management system governing the manufacture of this product is ISO 9001:2008-certified (specifies the requirements of a quality management system).

\section{Peer-Reviewed References}

No peer-reviewed publications were found that demonstrate the use of this product for the detection of biothreat agents.

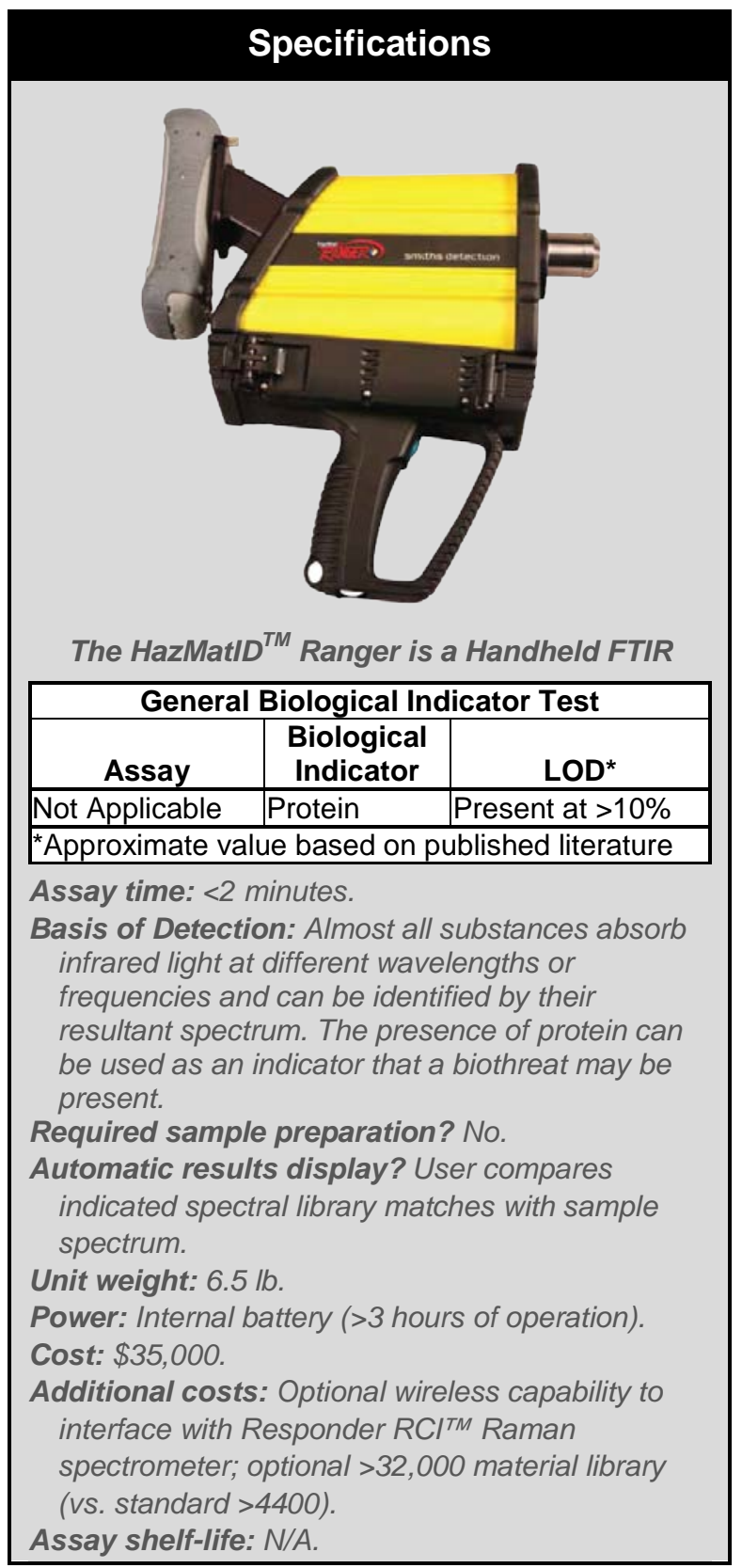

Required sample preparation? No.

Automatic results display? User compares indicated spectral library matches with sample spectrum.

battery ( $>3$ hours of operation). interface with Responder RCI ${ }^{\mathrm{TM}}$ Raman spectrometer; optional >32,000 material library . 


\section{Thermo Scientific: TruDefender ${ }^{\circledR}$ FT and FTi (FTIR)}

Product Link: http://www.thermoscientific.com/en/product/trudefender-ft-trudefender-fti-handheld-chemical-identification.html

Contact: Tom Keller (tom.keller@thermofisher.com)

Phone: (480) 532-6171 Manufacturer's website: http://www.ahurascientific.com

\section{Technology Summary}

The TruDefender $^{\circledR}$ FT and FTi are handheld FTIR instruments for analyzing and identifying chemical substances, including white powders, explosives, narcotics, and chemical weapons. The FTi version adds wireless communication, allowing results to be transmitted via email or text message. Thermo Scientific does not recommend the system for identification or detection of biological material due to the low sensitivity of FTIR in general for accurately detecting biological materials in suspicious powders.

A sample is analyzed by contacting the diamond ATR sensor head directly to a liquid or solid sample. A "sample crusher," or sampling platform, is included for analyzing solid samples and volatile liquids. Once a sample is scanned, spectral results are compared to a library of known spectra. The current spectral library (version 1.5) contains over 10,000 spectra; users can also add custom spectra to the library. In addition, TruDefender ${ }^{\circledR}$ software uses an automated proprietary algorithm for analyzing mixtures of chemicals without manual spectral subtraction and subjective evaluation. The TruDefender ${ }^{\circledR}$ series is designed to be used in a hot zone by a user wearing a Level A protective suit. For decontamination, the unit can be immersed in water and household bleach (5\% sodium hypochlorite).

The management system governing the manufacture of this product is ISO 9001:2008-certified (specifies the requirements of a quality management system).

\section{Peer-Reviewed References}

No peer-reviewed publications were found that demonstrate the use of this product for the detection of biothreat agents.

\section{Specifications}

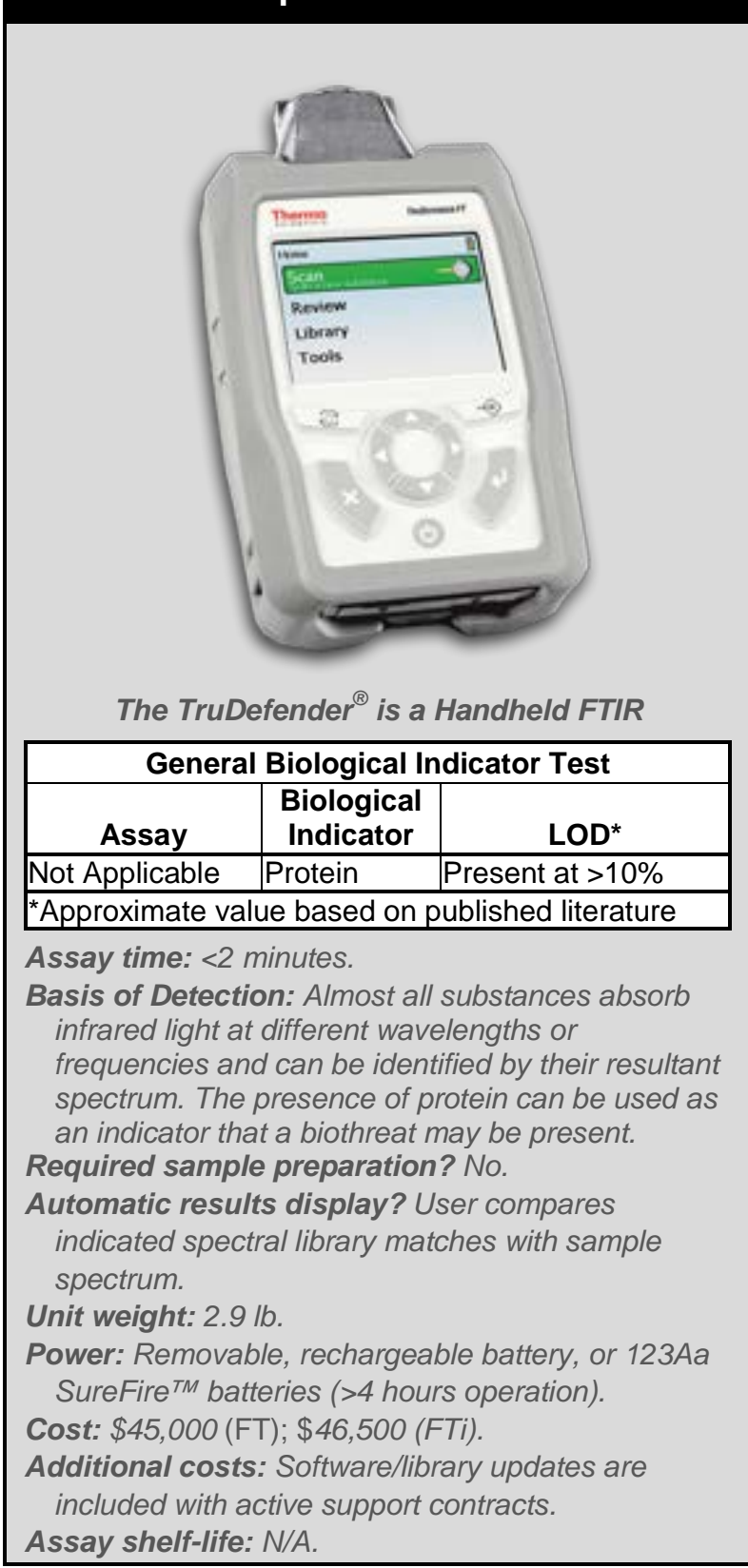




\section{$3 M^{\mathrm{TM}}:$ Clean-Trace ${ }^{\mathrm{TM}}$ Surface ATP (ATP Test)}

Product Link: http://solutions.3m.com/wps/portal/3M/en_US/Microbiology/FoodSafety/product-applications/four/ Contact: Josh Woodward (jwoodward@mmm.com)

Phone: (866) 290-0795 (Ext. 15) Manufacturer's website: http://solutions.3m.com

\section{Technology Summary}

The Clean-Trace ${ }^{\mathrm{TM}}$ system detects the presence of living bacterial cells by measuring the amount of ATP in a sample. ATP is a cellular metabolite present in all living cells. The amount of ATP in a sample is typically proportional to the number of living cells. The system has two main components: a handheld luminometer to read ATP-induced luminescence and an integrated swab/reagent cartridge. Once a sample is swabbed from a surface, the swab cartridge is inserted into the luminometer and the intensity of emitted light (luminescence) is displayed as relative light units (RLU) within 30 seconds. The total time required for the entire process is $<2$ minutes. In general, an RLU reading of $>300$ is considered positive, but the threshold RLU for establishing a positive result can depend on the particular surface (e.g., a food preparation surface may have high background readings if any animal or vegetable cellular material is present). While the integrated reagent/swab is easy to use, no sample-treatment steps facilitate discrimination of bacterial cells from other cells (e.g., food and skin cells). Ricin and botulinum toxins are not directly detected by this method, but detection of ATP present in any residual live cells that are associated with these toxins is possible. The Clean-Trace ${ }^{\mathrm{TM}}$ system is primarily marketed to the food industry as a rapid means of assessing whether a surface has been cleaned properly and has not been widely tested for biothreat applications. Because spores are not metabolically active cells and do not contain high levels of ATP, they are essentially undetectable using this system unless an incubation step is performed to initiate germination and cell growth, which is not currently part of the manufacturer's procedure.

The management system governing the manufacture of this product is ISO 9001:2008-certified (specifies the requirements of a quality management system).

\section{Peer-Reviewed References}

No peer-reviewed publications were found that demonstrate the use of this product for the detection of biothreat agents. 


\section{New Horizons Diagnostics, Inc.: PROFILE ${ }^{\circledR} 1$ (ATP Test)}

Product Link: http://www.nhdiag.com/profile_one.shtml

Contact: Larry Loomis (larryl@nhdiag.com)

Phone: (443) 543-5755 Manufacturer's website: http://www.nhdiag.com

\section{Technology Summary}

The PROFILE ${ }^{\circledR} 1$ detects the presence of living bacterial cells by measuring the amount of ATP in a sample. ATP is a cellular metabolite present in all living cells. The amount of ATP in a sample is typically proportional to the number of living cells. The test can distinguish microbial cells from bacterial spores and human cells through the use of sample preparation methods that selectively remove the microbial cells. The system has two main components: a microluminometer to read ATP-induced luminescence and a filtration device and cuvette combined (i.e., filtravette) to concentrate cells from a sample solution and remove chemical contaminants that may interfere with the test. Samples and solutions are processed through the filtravette using an empty syringe. After the sample is processed, a solution is applied to remove non-microbial sources of ATP. Then, a microbial lysis solution is added to the filtravette, followed by a luciferase solution that produces light in the presence of ATP. After pipette mixing, the filtravette is placed in the optical reader and the intensity of emitted light (luminescence) is recorded. Because they are proteins and not living cells, ricin and botulinum toxins are not directly detected by this method unless residual live cells associated with these toxins are present.

Spores do not contain high levels of ATP and are essentially undetectable using the PROFILE ${ }^{\circledR} 1$ kit unless an incubation step is performed to initiate cell growth. When analyzing a suspected anthrax spore powder, the sample must be incubated in growth media for 15 minutes. Note: using this method, powders containing yeast cells or bacteria, either from contamination or as an integral component (e.g., Dipel dust is a biological insecticide that contains Bacillus thuringiensis) will also give a positive result. Additional methods have been developed by NHD to minimize these artifacts when analyzing suspicious powder samples for Bacillus anthracis spores.

The PROFILE ${ }^{\circledR} 1$ is primarily marketed to the food safety industry as an alternative to culture methods to rapidly determine if a sample contains viable organisms.

\section{Specifications}

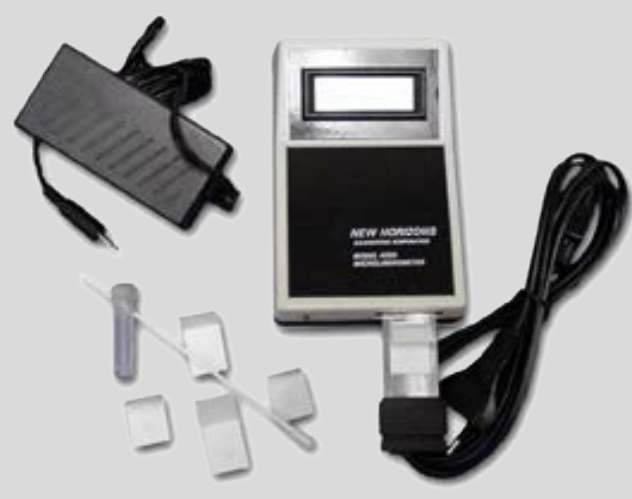

PROFILE ${ }^{\circledR} 1$ Kit for Detection of Live Cells

\begin{tabular}{|c|c|c|}
\hline \multicolumn{3}{|c|}{ General Biological Indicator Test } \\
\hline Assay & Biological Indicator & LOD* \\
\hline PROFILE $^{(} 1$ & ATP & $\begin{array}{l}\text { See comparab } \\
\text { for spores ** }\end{array}$ \\
\hline \multicolumn{3}{|c|}{$\begin{array}{l}\text { * Reported in peer-reviewed reference } \\
\star \star \text { Approximately } 2000-10,000 \text { spores } / \mathrm{mL}\end{array}$} \\
\hline \multicolumn{3}{|c|}{$\begin{array}{l}\text { Assay time: } \sim 15 \text { minutes (longer growth times can be used to } \\
\text { improve sensitivity). }\end{array}$} \\
\hline \multicolumn{3}{|c|}{$\begin{array}{l}\text { Basis of Detection: Presence of ATP (requires live, } \\
\text { metabolically active biological material); does not } \\
\text { distinguish between biothreat and non-threat materia } \\
\text { Required sample preparation? Moderate. }\end{array}$} \\
\hline \multicolumn{3}{|l|}{ Requ } \\
\hline \multicolumn{3}{|c|}{$\begin{array}{l}\text { Automatic results display? User interprets numerical } \\
\text { readout. }\end{array}$} \\
\hline \multicolumn{3}{|c|}{ Unit Weight: <1 lb. } \\
\hline \multicolumn{3}{|c|}{ Power: $9 \mathrm{~V}$ battery $(1000+$ reads) or AC. } \\
\hline \multicolumn{3}{|c|}{$\begin{array}{l}\text { Cost: Assay - } \$ 450 \text { (reagents and materials for } 100 \text { tests; } \\
\$ 4.50 \text { ea); instrument - } \$ 5000 \text { (includes carrying kit, } \\
\text { microluminometer, filtravette, and pipettor). }\end{array}$} \\
\hline \multicolumn{3}{|c|}{ Additional costs: None. } \\
\hline \multicolumn{3}{|c|}{$\begin{array}{l}\text { Assay shelf-life: } 12 \text { months from date of manufacture (some } \\
\text { reagents require refrigeration). }\end{array}$} \\
\hline
\end{tabular}




\section{Peer-Reviewed References}

Poore, C.; Clark, P.; Emanuel, P. A. An Evaluation of Suspicious Powder Screening Tools for First Responders. J. Hazard. Mater. 2009, 172, 559-65. DOI: 10.1016/j.jhazmat.2009.05.142.

This study compared the effectiveness of three general biological indicator tests to differentiate suspicious powders from biological threat agents. Test samples included Bacillus anthracis (Sterne strain) (washed 2 or 4 times to impact the amount of extraneous DNA and cellular protein on spore surfaces), Yersinia pestis (A1122 strain), and purified ricin. Note that these studies were performed with biothreat samples added directly to the kit solutions; thus, LODs are not reported as substance per milliliter (i.e., concentration). The 20/20 Gene Systems BioCheck ${ }^{\circledR}$ Powder Screening kit (protein test) could detect $1 \times 10^{8} \mathrm{CFU}$ of Bacillus anthracis (4X wash), $1 \times 10^{7} \mathrm{CFU}$ of Bacillus anthracis (2X wash), $1 \times 10^{7} \mathrm{CFU}$ of Yersinia pestis, and $100 \mu \mathrm{g}$ of ricin. The GenPrime Prime Alert ${ }^{\circledR}$ (DNA test) could detect $2 \times 10^{10} \mathrm{CFU}$ of Bacillus anthracis (4X wash), $1 \times 10^{9} \mathrm{CFU}$ of Bacillus anthracis ( $2 \mathrm{X}$ wash), and $1 \times 10^{8} \mathrm{CFU}$ of Yersinia pestis. The New Horizons Diagnostics PROFILE ${ }^{\circledR} 1$ (ATP test) could detect $1 \times 10^{4}$ CFU of Bacillus anthracis (both $2 \mathrm{X}$ and $4 \mathrm{X}$ wash) and $1 \times 10^{6} \mathrm{CFU}$ of Yersinia pestis. Because purified ricin was used the Prime Alert $^{\circledR}$ and PROFILE ${ }^{\circledR} 1$ were unable to detect ricin since neither DNA nor ATP was present from residual castor beans. Some of the 16 powders tested impacted sensitivity of the tests. In general, all kits gave positive results for powders that contained the targeted substance (e.g., protein or cells), but some powders caused interferences and impacted sensitivity as discussed in the Conclusions section.

Min, J.; Lee, J.; Deininger, R. A. Simple and Rapid Method for Detection of Bacterial Spores in Powder Useful for First Responders. Journal of Environmental Health 2006, 68 (8).

This study evaluated how changing variables in the protocol used by the New Horizons Diagnostics PROFILE $^{\circledR} 1$ impact the speed and sensitivity of detection of ATP. Sample sizes of $1 \mathrm{mg}$ Bacillus thuringiensis spores were used to investigate the impact of germination time (2, 5, 15 minutes), germination temperature $\left(37^{\circ} \mathrm{C}\right.$ vs. $\left.55^{\circ} \mathrm{C}\right)$, nutrient type (brain heart infusion [BHI] media vs. tryptic soy broth), and nutrient concentration ( $0.5 \mathrm{X}, 1 \mathrm{X}$ or $2 \mathrm{X}$ strength). The germination step converts the dormant spores to live vegetative cells that contain ATP. Germination also improves the method sensitivity during the short nutrient growth step, which increases the number of cells. The protocol involves adding an aliquot of the sample/buffer solution to a disposable filter tube, adding somatic cell-releasing agent and filtering to remove non-bacterial cells, which leaves the Bacillus cells on the filter surface. Bacterial cellreleasing agent is added to lyse the Bacillus cells, then luciferine-luciferase reagent is added, which binds with ATP and generates light that is read by a luminometer. Optimum conditions found were: 1) $37^{\circ} \mathrm{C}$ germination temperature, 2) 15 minute germination time, and 3) 1X strength of BHI.

Lee, J-Y.; Deininger, R. A. A Rapid Screening Method for the Detection of Viable Spores in Powder Using Bioluminescence. Luminescence 2004, 19, 209-211. DOI: 10.1002/bio.775.

This paper explores different sample preparation methods to speed the germination and subsequent detection of ATP in Bacillus thuringiensis (a surrogate for Bacillus anthracis) spores. The ATP bioluminescence method was used to detect the presence of spores in powder. Only spore-containing powder samples provided a dramatic increase in the bioluminescence signal after heat shock, which induces germination of spores and results in vegetative cells that have ATP. At $37^{\circ} \mathrm{C}$ the assay required approximately 15 minutes, while at $50^{\circ} \mathrm{C}$ spore germination was faster, resulting in a protocol that only required about 2 minutes. For the PROFILE ${ }^{\circledR} 1$ system, the authors reported the detection of $<100$ spores in a $50 \mu \mathrm{L}$ sample, which is 2000 spores $/ \mathrm{mL}$. 


\section{GenPrime, Inc.: Prime Alert ${ }^{\circledR}$ (DNA Test)}

Product Link: http://www.genprime.com/products_primealert.asp

Contact: Darby McLean (dmclean@genprime.com)

Phone: (866) 624-9855 Manufacturer's website: http://www.genprime.com

\section{Technology Summary}

The Prime Alert ${ }^{\circledR}$ System is designed to test for biological material in a white powder sample based on the presence of DNA or double-stranded RNA. This system is also distributed through Smiths Detection.

The Prime Alert $^{\circledR}$ System detects any type of DNA-based microbial or cellular material, not just anthrax or other biothreat DNA. The test is not specific to an individual organism and only indicates if the sample contains DNA or some types of RNA. The assay consists of a binding dye that fluoresces only when bound to DNA or certain RNA. Fluroescence emission is read by a handheld fluorometer included with the system. A calibration standard is included with the kit and used to calibrate the fluorescent optical reader before each use. Following a 1 minute reader calibration step that involves reading an included calibration solution, the assay takes approximately 5 minutes to complete. To perform the test, Cell Prep Solution is added to a glass sample vial dropwise from a dropper bottle and dye solution is added using a provided transfer pipette. Then the powder sample is added to the Cell Prep Solution dropper bottle and mixed by shaking.

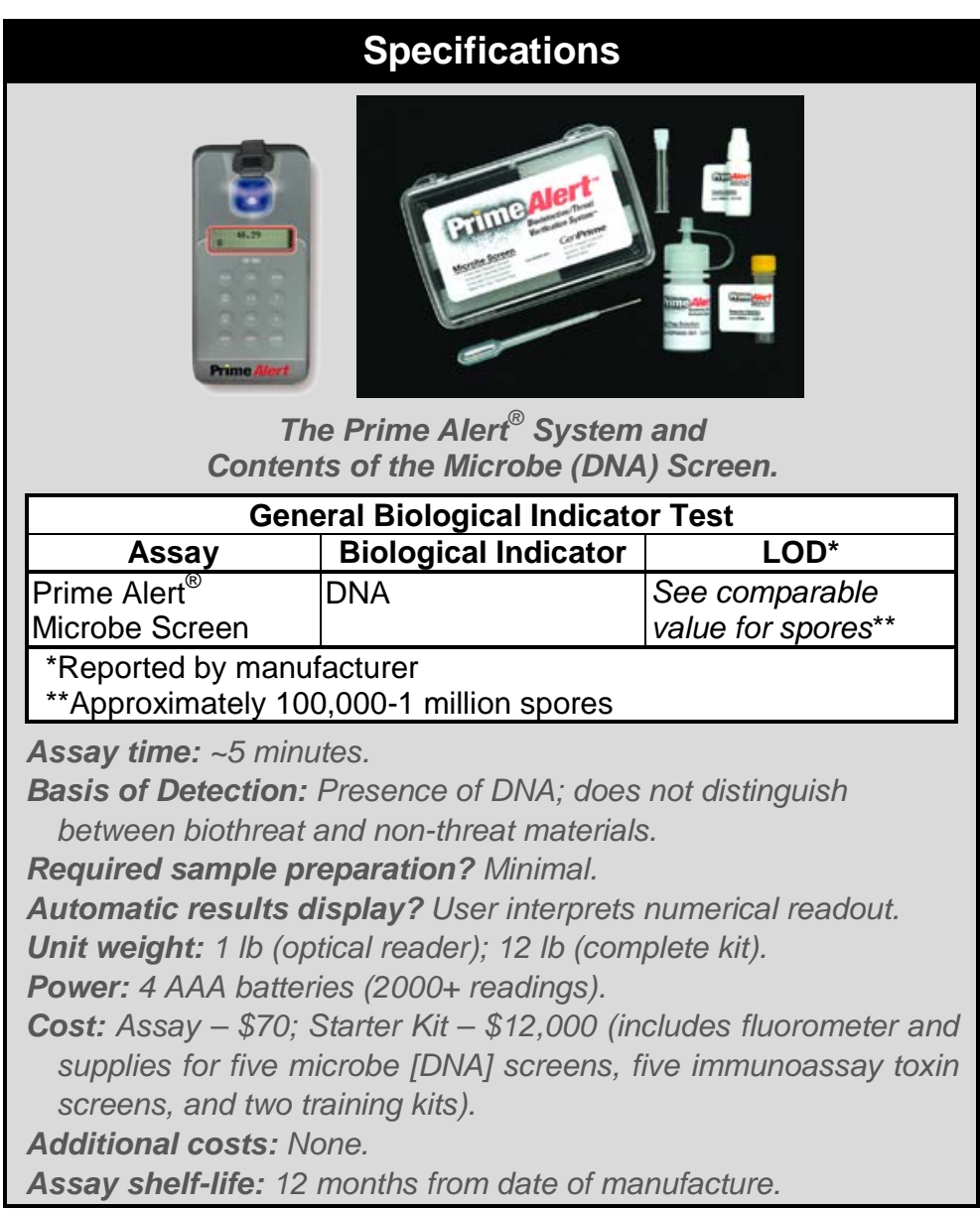
Four drops of this solution are added to the sample vial and then the vial is placed in the reader for analysis. The operator interprets the numerical readout based on a cutoff specified by the vendor.

The management system governing the manufacture of this product is ISO 13485:2003-certified (specifies the requirements of a quality management system for medical devices).

\section{Peer-Reviewed References}

Poore, C.; Clark, P.; Emanuel, P. A. An Evaluation of Suspicious Powder Screening Tools for First Responders. J. Hazard. Mater. 2009, 172, 559-65. DOI: 10.1016/j.jhazmat.2009.05.142.

This study compared the effectiveness of three general biological indicator tests to differentiate suspicious powders from biological threat agents. Test samples included Bacillus anthracis (Sterne strain) (washed 2 or 4 times to impact the amount of extraneous DNA and cellular protein on spore surfaces), Yersinia pestis (A1122 strain), and purified ricin. Note that these studies were performed with biothreat samples added directly to the kit solutions; thus, LODs are not reported as substance per milliliter (i.e., concentration). The 20/20 Gene Systems BioCheck ${ }^{\circledR}$ Powder Screening kit (protein test) could detect 
$1 \times 10^{8} \mathrm{CFU}$ of Bacillus anthracis (4X wash), $1 \times 10^{7} \mathrm{CFU}$ of Bacillus anthracis (2X wash), $1 \times 10^{7} \mathrm{CFU}$ of Yersinia pestis, and $100 \mu \mathrm{g}$ of ricin. The GenPrime Prime Alert ${ }^{\circledR}$ (DNA test) could detect $2 \times 10^{10} \mathrm{CFU}$ of Bacillus anthracis (4X wash), $1 \times 10^{9}$ CFU of Bacillus anthracis ( $2 \mathrm{X}$ wash), and $1 \times 10^{8}$ CFU of Yersinia pestis. The New Horizons Diagnostics PROFILE ${ }^{\circledR} 1$ (ATP test) could detect $1 \times 10^{4}$ CFU of Bacillus anthracis (both $2 \mathrm{X}$ and $4 \mathrm{X}$ wash) and $1 \times 10^{6} \mathrm{CFU}$ of Yersinia pestis. Because purified ricin was used the Prime Alert $^{\circledR}$ and PROFILE ${ }^{\circledR} 1$ were unable to detect ricin since neither DNA nor ATP was present from residual castor beans. Some of the 16 powders tested impacted sensitivity of the tests. In general, all kits gave positive results for powders that contained the targeted substance (e.g., protein or cells), but some powders caused interferences and impacted sensitivity as discussed in the Conclusions section. 


\subsection{Immunoassays}

Biodetection immunoassays differentiate and detect the presence of specific threats (pathogen and toxin) in a sample. These assays use antibodies, which are proteins designed (by nature or in the laboratory) to bind to a specific threat agent.

Most field-based immunoassays use an LFA format similar to a home pregnancy test. An LFA includes an assay strip containing all the assay components encased in a plastic cartridge. The cartridge has a sample window where the sample is applied to the assay strip and a results window where the results are read. LFAs require liquid samples; thus, they typically require a swab collection kit that

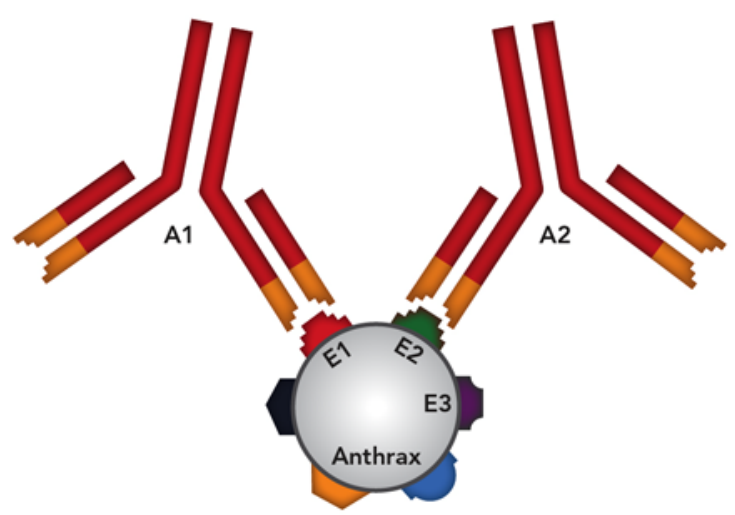

Schematic drawing of two different antibodies (A1 and A2) binding to two different regions (E1 and E2) on a biothreat agent. solubilizes material from the swab into a buffer. After a sample is collected, approximately 5 or 6 drops $(<0.5 \mathrm{~mL})$ of sample solution are added to the sample inlet window. The sample solution is wicked across the strip and through a reagent zone that contains dye-labeled antibodies specific to the threat agent. Threat agent molecules in the sample bind to the colored antibody-dye as the sample passes through this zone. The sample continues to be wicked into a capture zone containing a second set of antibodies that bind the threat agent/antibody-dye complex. The secondary antibodies in the capture zone are immobilized in a line across the strip so that, as capture proceeds, a visible colored line (the test line) develops in the test window. Adjacent to the capture zone is a control zone that contains immobilized antibodies (the control line) that bind to the antibody-dye directly. For an assay to be considered positive, both the test and control lines must be visible. For an assay to be considered negative, only the control line should be visible.

Immunoassays are advantageous because they are relatively inexpensive, require little skill to use, and results can be obtained in only 5 to 15 minutes. However, the specificity and sensitivity of immunoassays vary depending primarily on the quality of the antibodies used in the assay. For example, some antibodies can bind very low concentrations of biothreat agent resulting in a very sensitive assay. Other antibodies may bind the desired biothreat but also have some affinity for closely related biothreats (like nonpathogenic relatives of Bacillus anthracis that are found naturally in the

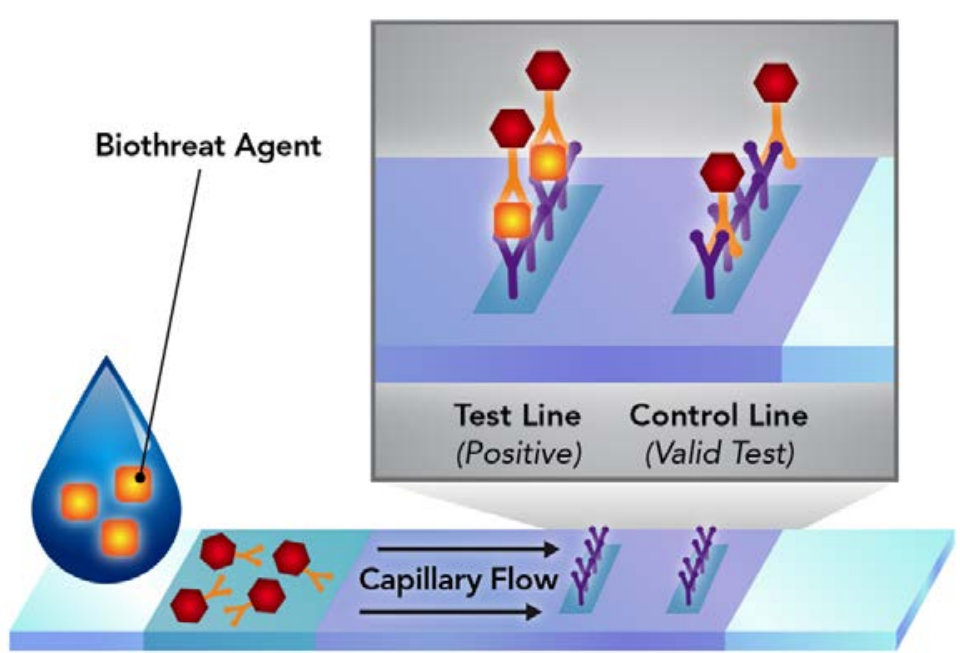

Illustration of a typical lateral flow immunoassay. environment). Furthermore, immunoassays are subject to false negatives resulting from interferents and highly concentrated samples. For example, if there are more biothreat agents than dye-labeled antibody reagents, unlabeled biothreat agents may bind to the test line and effectively block the labeled biothreat 
agents from binding. In this situation, the sample line would be negative and the control line may or may not be positive (depending on the assay design). False positives may also result from certain nonhazardous substances. Typical LODs for immunoassays range from 100,000 to 10 million spores or microbes. Automated sample processing and detection systems can improve sensitivity by 10 -fold or more.

\section{Single Agent Tests}

- Assay cost: $\sim 25$ to $\$ 40$

- Optical reader cost: $\$ 3500$ to $\$ 11,500$ (optional for most)

- Note: Optical readers can improve sensitivity and accuracy and may help to identify a hook effect (excess threat agent) condition that may result in a false-negative

- Examples:

- BADD $^{\mathrm{TM}}$ (AdVnt Biotechnologies)

- BioDetect $^{\mathrm{TM}}$ (Alexeter Technologies) with portable and handheld optional optical readers (\$7500, $\$ 10,000)$

- ENVI Assay System Gold (Environics) with optional optical reader (\$3452) (requires ChemPro ${ }^{\circledR} 100$ module $(\$ 14,995)$ or PC software $(\$ 540)$, PC not included)

- Smart $^{\mathrm{TM}}$-II (New Horizons Diagnostics)

- $\quad$ RAMP $^{\circledR}$ (Response Biomedical) with required optical fluorescence reader (\$6995)

- BioThreat Alert ${ }^{\circledR}$ (Tetracore) with optional optical reader $(\$ 5500)$

\section{Multiple Agent Tests}

- 2- to 8-agent assays

- Assay cost: $\$ 70$ to $\$ 120$

- Examples:

- Pro Strips $^{\mathrm{TM}}$ (AdVnt Biotechnologies)

- RAID $^{\mathrm{TM}}$ (Alexeter Technologies)

- NIDS $^{\circledR}$ (ANP Technologies) with optional optical reader (\$5500)

- IMASS (BBI Detection)

- Toxin Screen (GenPrime)

\section{Automated Immunoassay Systems}

- Zephyr ${ }^{\circledR}$ (Path Sensors)

- 1-agent assays

- Assay cost: \$16 per 1-agent assay

- Instrument cost: $\$ 23,490$

- BIOSENSOR ${ }^{\mathrm{TM}}$ 2200R (QTL Biosystems)

- 2-agent assay

- Assay cost: \$80 (1-agent assay), \$100 (2-agent assay)

- Instrument cost: $\$ 16,000$ 
- BioHawk ${ }^{\circledR}$ (Research International)

- 8-agent assay

- Assay cost: \$250 per 8-agent assay

- Instrument cost: $\$ 65,000$

- RAPTOR ${ }^{\mathrm{TM}}$ (Research International)

- 4-agent assay

- Assay cost: $\$ 200(<100)$ or $\$ 143(>500)$ per 4-agent assay

- Instrument cost: $\$ 49,500$ 


\section{AdVnt Biotechnologies, LLC: BADD ${ }^{\mathrm{TM}}$}

Product Link: http://www.advnt.org/products/biowarfare/baddbox

Contact: Tim Scherkenback (tims@advnt.org)

Phone: (888) 223-3269 Manufacturer's website: http://www.advnt.org/ Tim Scherkenback

\section{Technology Summary}

The AdVnt Biowarfare Agent Detection Devices (BADD ${ }^{\mathrm{TM}}$ ) are LFAs for the detection of specific biothreats. These devices test for one agent at a time. Each test comes with an all-inone swab kit that contains a swab, sample buffer, and pipette/dropper tube. Following sampling, the test is initiated by adding five or six drops ( $\sim 0.2 \mathrm{~mL}$ ) of sample to the sample inlet window. Results can be seen in 15 minutes. However, with concentrated samples a positive result may be obvious after only 3 minutes.

One line in the control zone indicates the agent was not detected, two lines (one in the control zone and one in the test zone) indicate the agent was detected. The absence of a control line indicates the assay is invalid and any positive or negative test result must be disregarded.

The management system governing the manufacture of this product is ISO 9001:2008-certified (specifies the requirements of a quality management system) and ISO 13485:2003-certified (specifies the requirements of a quality management system for medical devices). This product has received a "Certified" classification (consistently proven effectiveness, with high confidence of enduring effectiveness) by DHS as part of its Support Anti-terrorism by Fostering Effective Technologies (SAFETY) Act of 2002 (www.safetyact.gov).

\section{Peer-Reviewed References}

Peckham, G. D.; Hew, B. E.; Waller, D. F.; Holdaway, C.; Jen, M. Amperometric Detection of Bacillus Anthracis Spores: A Portable, Low-Cost Approach to the Elisa. Int. J. Electrochem. 2013, 2013, Article 803485. DOI: 10.1155/2013/803485. http://www.hindawi.com/journals/ijelc/2013/803485/

This investigation compared an antibody-based method using amperometric signal generation to enzyme-linked immunosorbent assays (ELISAs) and LFAs for detecting Bacillus anthracis (Sterne strain)

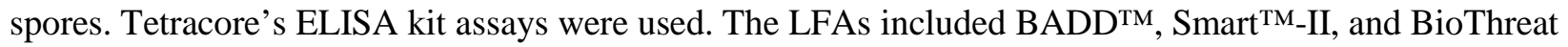

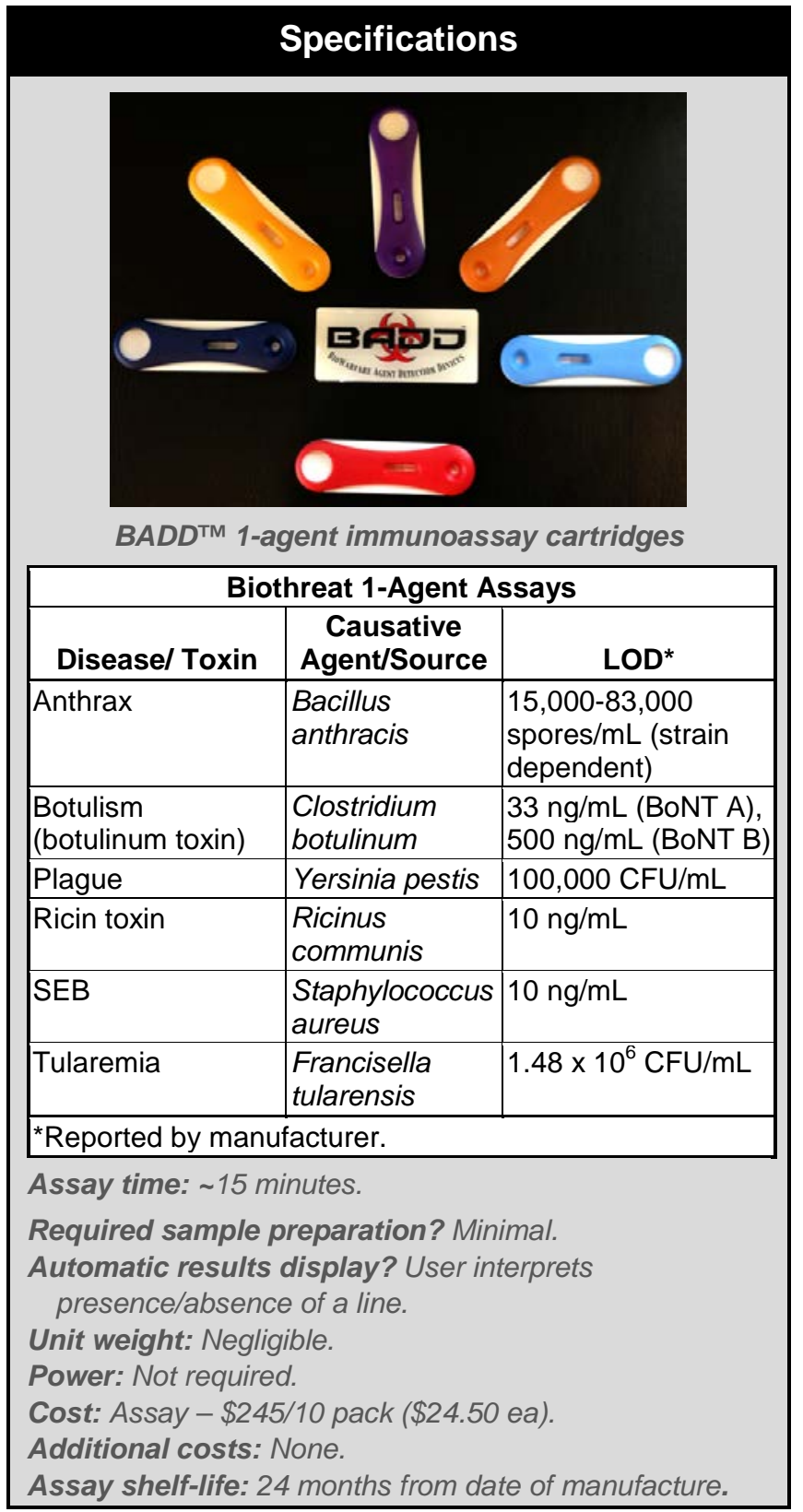


Alert $^{\circledR}$. At least 15 of each LFA were tested with spore concentrations of $10^{4} \mathrm{CFU} / \mathrm{mL}$ to $5 \times 10^{6}$ CFU/mL. All LFAs detected $5 \times 10^{6} \mathrm{CFU} / \mathrm{mL}$ in greater than $>90 \%$ of trials. Performance decreased with decreasing spore concentration ( $<80 \%$ for $10^{6} \mathrm{CFU} / \mathrm{mL}$ and $<60 \%$ for $5 \times 10^{5} \mathrm{CFU} / \mathrm{mL}$ ). Smart ${ }^{\mathrm{TM}}$-II was the only immunoassay tested that detected samples with $10^{5} \mathrm{CFU} / \mathrm{mL}$, but this was achieved only in $<40 \%$ of trials. BioThreat Alert ${ }^{\circledR}$ was reported to be the easiest to interpret with a dark, highly contrasted test line. The BADD ${ }^{\mathrm{TM}}$ readout was reported to be very faint, even at high spore concentrations. ELISA had $100 \%$ positive detection for all spore concentrations, though each assay takes over 6 hours to complete. Amperometry, which required just over an hour to complete, detected spores in $>90 \%$ of trials at $>10^{5} \mathrm{CFU} / \mathrm{mL}$; however, the performance decreased with decreasing spore concentration (86\% for $5 \times 10^{4} \mathrm{CFU} / \mathrm{mL}$ and $47 \%$ for $10^{4} \mathrm{CFU} / \mathrm{mL}$ ).

Slotved, H.-C.; Tanassi, J. T.; Sparding, N.; Lindqvist, A.; Steenhard, N. R.; Heegaard, N. H. H. Botulinum Toxin Field Assays Evaluated Using Cosmetic Botox Preparations. Biosecurity and bioterrorism: biodefense strategy, practice, and science 2013, 11, 280-286. DOI: 10.1089/bsp.2013.0050.

This study compared several different botulinum detection technologies using botulinum toxins (BoNTs) A and B, as well as four pharmaceutical-grade cosmetic botulinum toxin preparations. An ELISA method was used as a baseline and compared to an immunoaffinity column and LFAs from AdVnt Biotechnologies (1-agent BADD ${ }^{\mathrm{TM}}$ and 5-agent ProStrips), Environics (ENVI Assay system), and Alexeter (RAID DX kit, which contains an 8-agent RAID 8 LFA and a 3-agent RAID TOX LFA). Relatively low concentrations of BoNTs (both commercial and pharmaceutical sources) were used and were not detected by most of the LFAs. BADD ${ }^{\text {TM }}$ did not detect pharmaceutical BoNT A (100 ng/mL), commercial BoNT A (50 ng/mL), or commercial BoNT B (500 ng/mL and 10,000 ng/mL). ProStrips did not detect commercial BoNT A (50 ng/mL and 10,000 ng/mL), commercial BoNT B (10,000 ng/mL), or pharmaceutical BoNT A (100 ng/mL). The ENVI Assay System gave one positive result and one negative result with commercial BoNT A (10,000 ng/mL), but did not detect pharmaceutical BoNT A (100 ng/mL and $27.5 \mathrm{ng} / \mathrm{mL}$ ). The RAID 8 and RAID TOX did not detect pharmaceutical BoNT A $(27.5 \mathrm{ng} / \mathrm{mL}$ and $13.75 \mathrm{ng} / \mathrm{mL}$ ), although those concentrations are below the manufacturer stated LOD for BoNT.

Gessler, F.; Pagel-Wieder, S.; Avondet, M-A. Bohnel, H. Evaluation of Lateral Flow Assays for the Detection of Botulinum Neurotoxin Type A and Their Application in Laboratory Diagnosis of Botulism. Diagn. Microbiol. Infect. Dis. 2007, 57, 243-249. DOI: 10.1016/j.diagmicrobio.2006.07.017.

This study evaluated BioThreat Alert ${ }^{\circledR}$, Smart ${ }^{\mathrm{TM}}-\mathrm{II}, \mathrm{BADD}^{\mathrm{TM}}$, and RAMP ${ }^{\circledR}$ assays for their ability to detect botulinum neurotoxin in three forms: purified botulinum neurotoxin A (BoNT/A), toxin complex, and toxin in the supernantant of a Clostridium botulinum culture. Only BADD ${ }^{\mathrm{TM}}$ and RAMP ${ }^{\circledR}$ detected purified BoNT/A; LODs were $100 \mathrm{ng} / \mathrm{mL}$ for BADD ${ }^{\mathrm{TM}}$ and $50 \mathrm{ng} / \mathrm{mL}$ for RAMP ${ }^{\circledR}$. All assays detected the BoNT/A complex and SMART ${ }^{\mathrm{TM}}-\mathrm{II}$ and BioThreat Alert had greater sensitivity for the BoNT/A complex $(10 \mathrm{ng} / \mathrm{mL})$ than BADD ${ }^{\text {TM }}(100 \mathrm{ng} / \mathrm{mL})$ and RAMP $^{\circledR}(250 \mathrm{ng} / \mathrm{mL})$. For the Clostridium botulinum culture samples, the concentration of active toxin was estimated using a mouse lethality assay. The lowest concentration of toxin in culture medium that the Biotherat Alert ${ }^{\circledR}$, Smart ${ }^{\mathrm{TM}}$-II, and BADD ${ }^{\mathrm{TM}}$ could detect was 100 Minimal mouse Lethal Doses (MLD)/mL, while RAMP ${ }^{\circledR}$ could detect only 2500 $\mathrm{MDL} / \mathrm{mL}$. BADD ${ }^{\mathrm{TM}}$ gave a false-positive result for a culture medium that did not contain Clostridium botulinum or toxin. 
King, D.; Luna, V.; Cannons, A.; Cattani, J.; Amuso, P. Performance Assessment of Three Commercial Assays for Direct Detection of Bacillus anthracis Spores. J. Clin. Microbiol. 2003, 41, 3454-3455. DOI:10.1128/JCM.41.7.3454-3455.2003.

This brief study by the Florida Department of Health Laboratory evaluated three immunoassay tests including BioThreat Alert ${ }^{\circledR}$, Osborne Scientific's $1^{\text {st }}$ generation BADD (Note: Osborne's biothreat product line was acquired by AdVnt in 2003 and the current assay is $3^{\text {rd }}$ generation), and Smart ${ }^{\mathrm{TM}}$-II. The tests were evaluated for Bacillus anthracis (Pasteur strain) detection at concentrations ranging from $10^{2}$ to $10^{6}$ spores (the concentration of the test samples and volume of sample applied were not reported). Only 2 to 8 samples were tested at each concentration. All test kits could detect Bacillus anthracis at $10^{6}$ spores. BADD $^{\text {TM }}$ and Smart ${ }^{\mathrm{TM}}$-II could detect $10^{5}$ spores; however, BioThreat Alert ${ }^{\circledR}$ detected $10^{5}$ spores only once in eight separate assays. None of the assays could detect fewer than 10,000 spores. Tests were allowed to develop for 15 minutes, although positive results were apparent within 5 minutes. Bacillus cereus and Bacillus thuringiensis (non-threat near neighbors that could potentially result in a falsepositive) were also tested twice for each test strip. No false positives were observed for the BADD ${ }^{\mathrm{TM}}$ or BioThreat Alert ${ }^{\circledR}$ tests; however, the Smart ${ }^{\mathrm{TM}}$-II tests yielded one false-positive result for Bacillus thuringiensis. 


\section{AdVnt Biotechnologies, LLC: Pro Strips ${ }^{\mathrm{TM}}$}

Product Link: http://www.advnt.org/products/biowarfare/prostrips

Contact: Tim Scherkenback (Tims@advnt.org)

Phone: (888) 223-3269 Manufacturer's website: http://www.advnt.org/

\section{Technology Summary}

AdVnt Pro Strips ${ }^{\mathrm{TM}}$ are, basically, five BADD $^{\mathrm{TM}}$ assays bundled into a single cartridge. In the Pro Strips ${ }^{\mathrm{TM}}$ assay, one sample is automatically divided among five different assays. Following sample collection with the included all-in-one swab kit, approximately 10 to 11 drops ( $0.4 \mathrm{~mL}$ ) of the solution are added to the sample inlet window. Results are read in a separate window for each agent tested.

One line in the control zone indicates the agent was not detected, two lines (one in the control zone and one in the test zone) indicate the agent was detected. The absence of a control line indicates the assay is invalid and any positive or negative test result must be disregarded.

The management system governing the manufacture of this product is ISO 9001:2008-certified (specifies the requirements of a quality management system) and ISO 13485:2003-certified (specifies the requirements of a quality management system for medical devices). This product has received a "Certified" classification (consistently proven effectiveness, with high confidence of enduring effectiveness) by DHS as part of its Support Anti-terrorism by Fostering Effective Technologies (SAFETY) Act of 2002 (www.safetyact.gov).

\section{Peer-Reviewed References}

No peer-reviewed publications were found that demonstrate the use of this product for the detection of biothreat agents.

\begin{tabular}{l}
\hline \multicolumn{2}{|c|}{ Specifications } \\
\hline \multicolumn{1}{|c|}{ Biothreat 5-Agent Assay } \\
\hline \multicolumn{1}{|c|}{ Causative } \\
\hline \begin{tabular}{l} 
Pro Strips \\
\hline TM
\end{tabular}
\end{tabular}




\section{Alexeter Technologies, LLC: BioDetect ${ }^{\mathrm{TM}}$}

Product Link: http://www.alexeter.com/biow/products/products/strips/anthrax.asp

Contact: Tom Fryzel (tfryzel@alexeter.com)

Phone: (877) 591-5571 Manufacturer's website: http://www.alexeter.com

\section{Technology Summary}

Alexeter BioDetect ${ }^{\mathrm{TM}}$ Test Strips are standard 1-agent LFAs. Each box of 25 assays includes $15 \mathrm{~mL}$ of buffer, 5 swabs, and 5 plastic vials. To initiate the assay, a 3 to 5 drop sample ( 150 to $250 \mu \mathrm{L})$ is dispensed into the sample window. After a 15 minute incubation, the test can be read with the Alexeter Guardian Reader ${ }^{\mathrm{TM}}$, Defender Test Strip Reader (TSR ${ }^{\mathrm{TM}}$ ), or manually.

One line in the control zone indicates the agent was not detected, two lines (one in the control zone and one in the test zone) indicate the agent was detected. The absence of a control line indicates the assay is invalid and any positive or negative test result must be disregarded. For the toxin assays, the manufacturer recommends running an additional test with a 1:40 dilution of the sample to minimize the possibility of using too much sample (i.e., the "hook effect," which can yield a falsenegative at high threat agent concentrations).

For increased accuracy and sensitivity, these test strips can be used with an optical reader (available separately). The primary advantages of using either optical reader are an objective interpretation of the test result and enhanced detection sensitivity (reported by the vendor as approximately 10 -fold). The Guardian ${ }^{\mathrm{TM}}$ Reader is approximately the size of a toaster, and the Defender ${ }^{\mathrm{TM}}$ TSR is handheld.

\section{Peer-Reviewed References}

No peer-reviewed publications were found that demonstrate the use of this product for the detection of biothreat agents.

\section{Specifications}

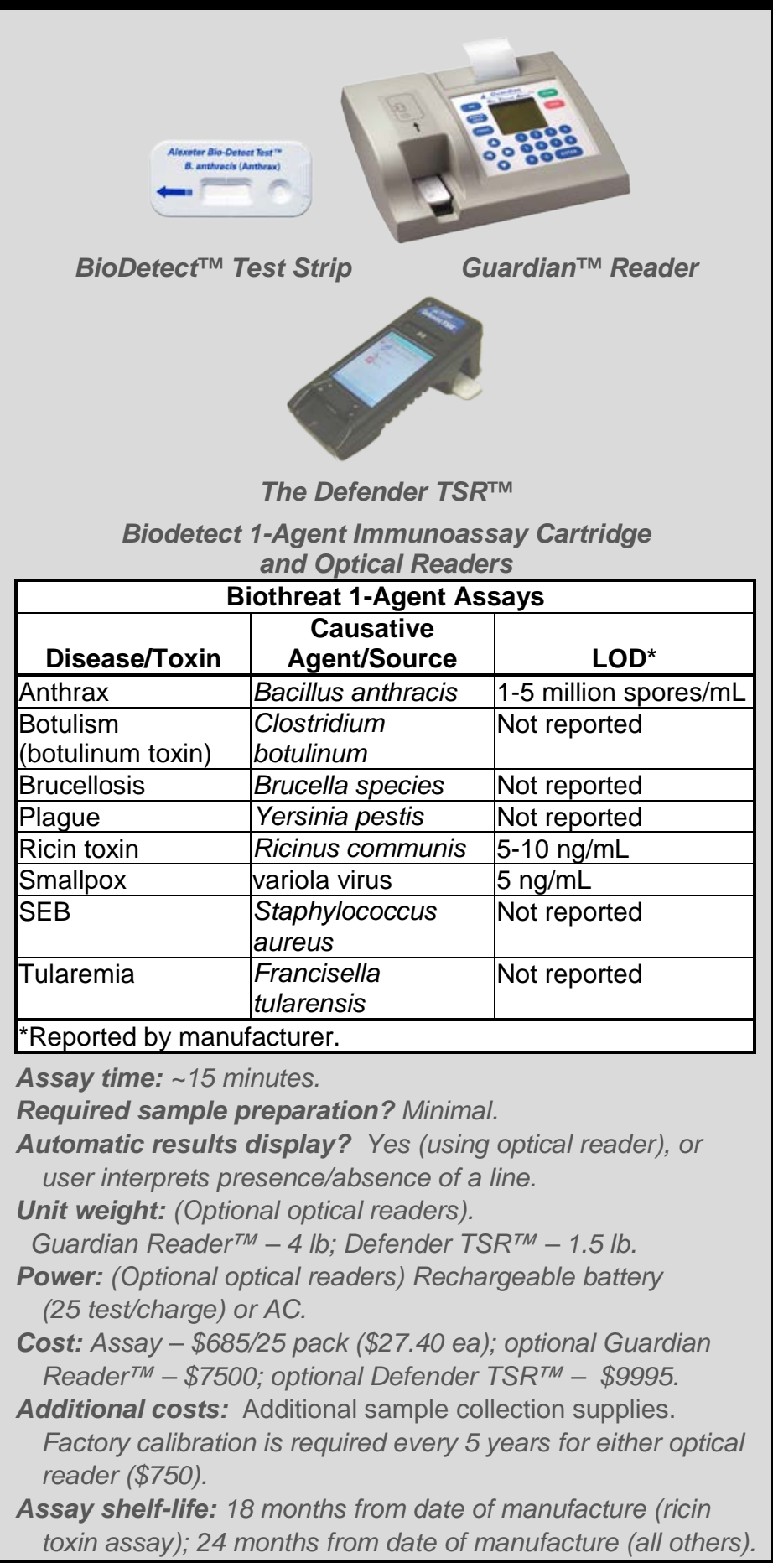




\section{Alexeter Technologies, LLC: RAID ${ }^{\mathrm{TM}}$}

Product Link: http://www.alexeter.com/biow/products/products/strips/RAID.asp

Contact: Tom Fryzel (tfryzel@alexeter.com)

Phone: (877) 591-5571 Manufacturer's website: http://www.alexeter.com

\section{Technology Summary}

Alexeter RAID ${ }^{\mathrm{TM}} 5$ and RAID $^{\mathrm{TM}} 8$ are multiplex LFA strips, which can test simultaneously for five and eight different agents, respectively, from a single sample. Each cartridge comes with a sampling tool that includes an integrated swab, buffer, and dropper dispenser. For the RAID ${ }^{\mathrm{TM}}$ tests, 6 drops of sample ( $\sim 300 \mu \mathrm{L})$ are applied to each sample window (RAID ${ }^{\text {TM }} 5$ has a single window; RAID ${ }^{\mathrm{TM}} 8$ has two windows). One line in the control zone indicates the agent was not detected, two lines (one in the control zone and one in the test zone) indicate the agent was detected. The absence of a control line indicates the assay is invalid and any positive or negative test result must be disregarded.

The RAID ${ }^{\mathrm{TM}}$ TOX (a companion toxin assay to the RAID ${ }^{\mathrm{TM}}$ assays) was developed to address concerns about the hook effect that can result in false-negative results if too much analyte, particularly toxin, is present in the sample. If a negative result is obtained on the RAID $^{\text {TM }} 8$ or RAID ${ }^{\text {TM }} 5$, a second, 50-fold diluted sample can be analyzed on the RAID ${ }^{\mathrm{TM}}$ TOX to address possible concerns about falsenegative toxin results. The RAID ${ }^{\mathrm{TM}}$ TOX includes assays for SEB, ricin, and botulinum toxins. Additional internal control assays are included, showing what a positive and negative result should look like. These assays are not compatible with the Alexeter Defender ${ }^{\mathrm{TM}}$ TSR or Guardian ${ }^{\mathrm{TM}}$ Reader.

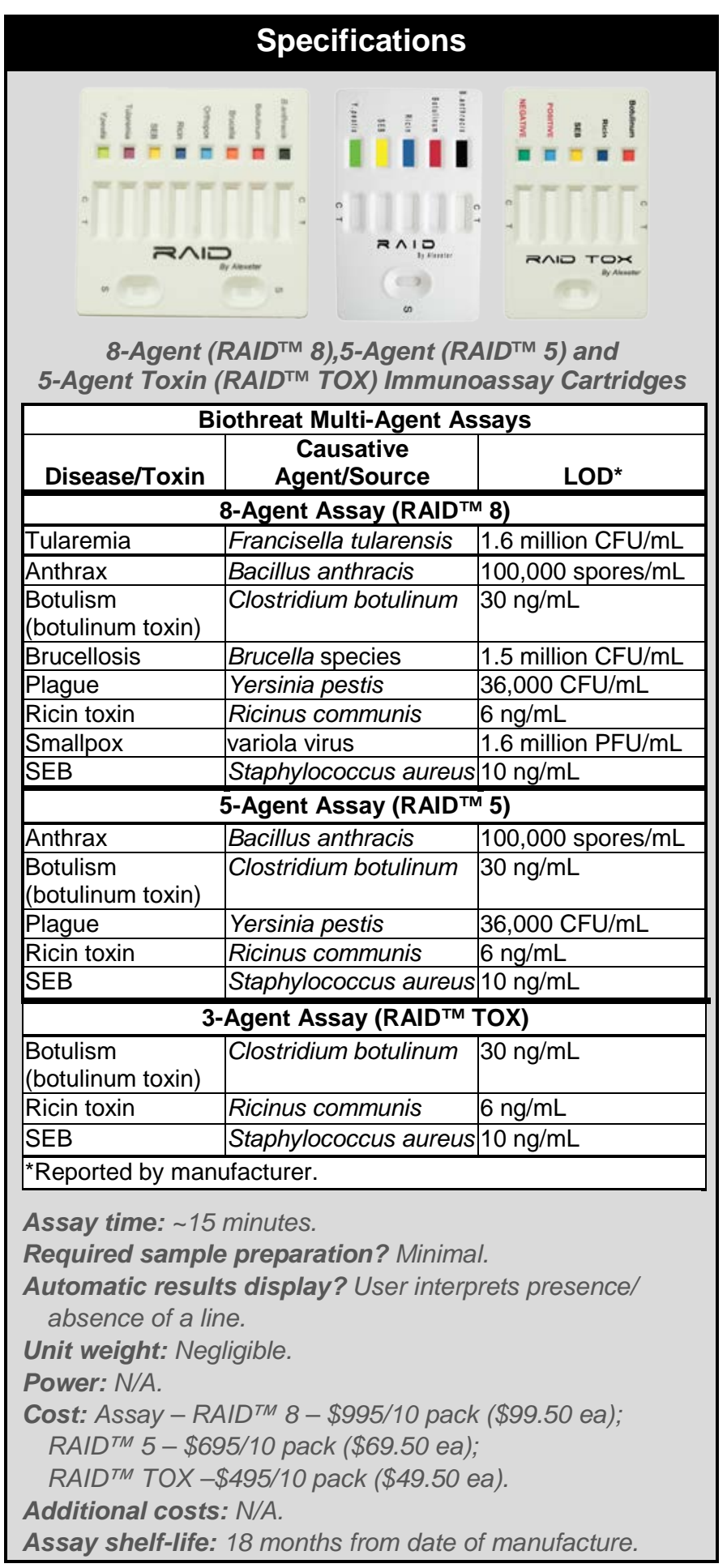




\section{Peer-Reviewed References}

Slotved, H.-C.; Tanassi, J. T.; Sparding, N.; Lindqvist, A.; Steenhard, N. R.; Heegaard, N. H. H. Botulinum Toxin Field Assays Evaluated Using Cosmetic Botox Preparations. Biosecurity and bioterrorism: biodefense strategy, practice, and science 2013, 11, 280-286. DOI: 10.1089/bsp.2013.0050.

This study compared several different botulinum detection technologies using botulinum toxins (BoNTs) A and B, as well as four pharmaceutical-grade cosmetic botulinum toxin preparations. An ELISA method was used as a baseline and compared to an immunoaffinity column and LFAs from AdVnt Biotechnologies (1-agent BADD ${ }^{\mathrm{TM}}$ and 5-agent ProStrips), Environics (ENVI Assay system), and Alexeter (RAID DX kit, which contains an 8-agent RAID 8 LFA and a 3-agent RAID TOX LFA). Relatively low concentrations of BoNTs (both commercial and pharmaceutical sources) were used and were not detected by most of the LFAs. BADD ${ }^{\mathrm{TM}}$ did not detect pharmaceutical BoNT A (100 ng/mL), commercial BoNT A (50 ng/mL), or commercial BoNT B (500 ng/mL and 10,000 ng/mL). ProStrips did not detect commercial BoNT A (50 ng/mL and 10,000 ng/mL), commercial BoNT B (10,000 ng/mL), or pharmaceutical BoNT A (100 ng/mL). The ENVI Assay System gave one positive result and one negative result with commercial BoNT A $(10,000 \mathrm{ng} / \mathrm{mL})$, but did not detect pharmaceutical BoNT A (100 ng/mL and $27.5 \mathrm{ng} / \mathrm{mL})$. The RAID 8 and RAID TOX did not detect pharmaceutical BoNT A $(27.5 \mathrm{ng} / \mathrm{mL}$ and $13.75 \mathrm{ng} / \mathrm{mL}$ ), although those concentrations are below the manufacturer stated LOD for BoNT. 


\section{ANP Technologies ${ }^{\circledR}$, Inc.: NIDS ${ }^{\circledR}$}

Product Link: http://anptinc.com/index.php?option=com_content\&view=article\&id=143\&Itemid=98

Contact: Ray Yin (ray@anptinc.com)

Phone: (302) 283-1730 Manufacturer's website: http://anptinc.com

\section{Technology Summary}

$\begin{aligned} & \text { The Nano } \\ & \text { Intelligent } \\ & \left(\mathrm{NIDS}^{\circledR}\right)\end{aligned}$
$\begin{aligned} & \text { Detection } \\ & \text { consists of LFA strips and an }\end{aligned}$
optional optical reader for
detection. Sample collection
supplies must be purchased
separately.

NIDS $^{\circledR}$ immunoassay strips are formatted for the detection of three, four, or five agents in a single cartridge. The manufacturer states that its proprietary method of immobilizing the capture antibodies in a uniform orientation on the test strips decreases the likelihood of hook effect artifacts that can produce false-negative results when very concentrated samples are analyzed.

After sample collection and solubilization, $100 \mu \mathrm{L}$ (about 5 drops) of sample is placed in the sample well of the test strip and the strip is allowed to develop for 15 minutes and placed into the optical reader for detection and automatic readout or it can be read manually. One line in the control zone indicates the agent was not detected, two lines (one in the control zone and one in the test zone) indicate the agent was detected. The absence of a control line indicates the assay is invalid and any positive or negative test result must be disregarded. This product is also available from Smiths Detection.

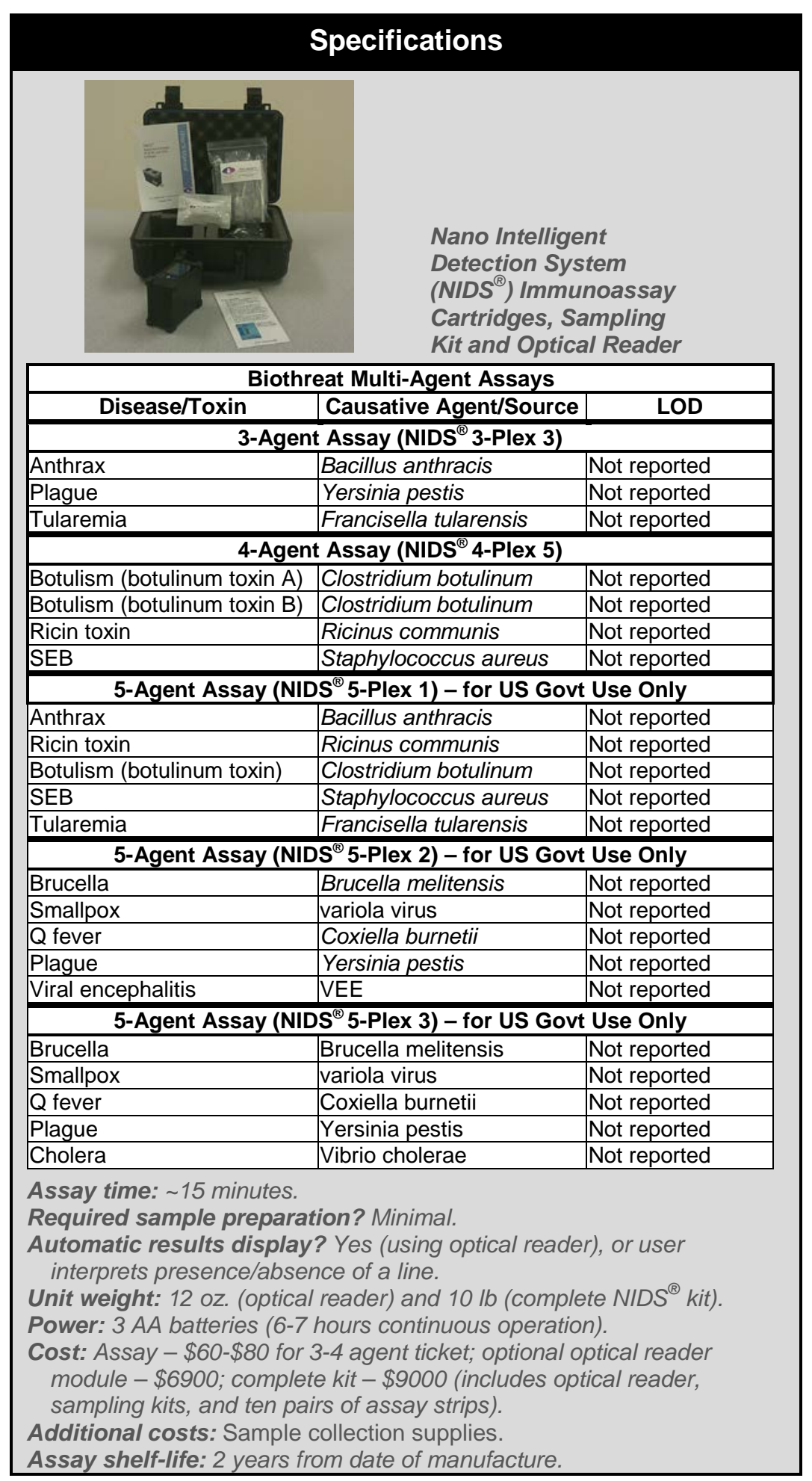


Three- and 4-agent assays are available for the general public, but the 5-agent assays are only available to federal government organizations. Customized assays for E. coli 0157, Salmonella, and Listeria are also available.

The management system governing the manufacture of this product is ISO 9001:2008-certified (specifies the requirements of a quality management system). This product (optical reader and immunoassay cartridges) has received a "Designated" classification (proven effectiveness, with confidence of repeatability) by DHS as part of its Support Anti-terrorism by Fostering Effective Technologies (SAFETY) Act of 2002 (www.safetyact.gov).

\section{Peer-Reviewed References}

No peer-reviewed publications were found that demonstrate the use of this product for the detection of biothreat agents. 


\section{BBI Detection, Inc.: IMASS ${ }^{\mathrm{TM}}$}

Product Link: http:/www.bbidetection.com/products/biothreat-detection-imass-device

Contact: Chris Feltham GRSC (ChrisFeltham@bbidetection.com)

Phone: (888) 223-3269 Manufacturer's website: http://www.bbidetection.com

\section{Technology Summary}

BBI Detection has developed a multiplex immunoassay LFA device with an integrated sampling system for surfaces, powders, or liquids. The device consists of a handheld cylinder that contains a sampling sponge at one end and eight lateral flow immunoassay strips integrated within the barrel of the cylinder. To initiate sampling, the user unscrews the end cap of the IMASS $^{\mathrm{TM}}$ device and adds the contents of a buffer solution bottle to the IMASS ${ }^{\mathrm{TM}}$ sponge. The user then wipes the IMASS ${ }^{\mathrm{TM}}$ sponge over the surface to be sampled and replaces the cap, screwing down tightly to engage the driving nut, which initiates the sample flow onto the LFAs. The device is placed vertically on a flat surface while the assay develops. Results from the eight LFAs can be read by eye in approximately 2 to 15 minutes.

One line in the control zone indicates the agent was not detected, two lines (one in the control zone and one in the test zone) indicate the agent was detected. The absence of a control line indicates the assay is invalid and any positive or negative test result must be disregarded.

The management system governing the manufacture of this product is ISO 9001:2008-certified (specifies the requirements of a quality management system) and ISO 13485:2003-certified (specifies the requirements of a quality management system for medical devices).

\section{Peer-Reviewed References}

No peer-reviewed publications were found that demonstrate the use of this product for the detection of biothreat agents.

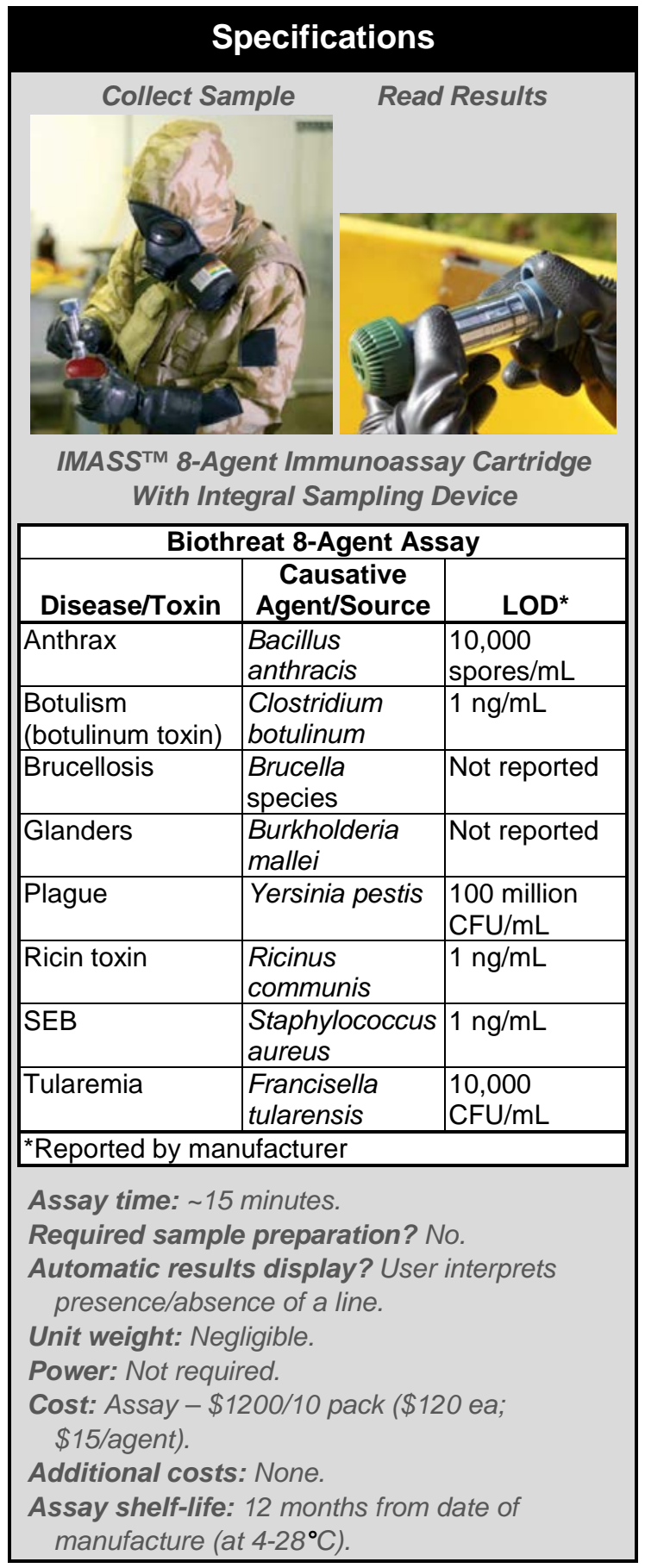




\section{Environics, Inc.: ENVI Assay System Gold}

Product Link: http://www.environics.fi/index.php/biological-detection/envi-assay-system

Contact: Chris Wrenn (sales@environicsusa.com)

Phone: (410) 612-1250 Manufacturer's website: http://www.environicsusa.com

\section{Technology Summary}

The Environics ENVI Assay System Gold is a colorimetric LFA that can be read by eye or with an optical reader. The Environics Reader Module is designed to be an add-on module for the ChemPro ${ }^{\circledR} 100$ Chemical Detector, but can be used alone if it is connected to a PC. The optical reader can be powered by a USB port or directly from the ChemPro ${ }^{\circledR} 100 \quad$ Chemical Detector. Colorimetric ENVI assays include all materials required for analysis (e.g., sampling swabs, buffers, and transfer pipettes) packaged in a box that doubles as a sample-preparation platform.

One line in the control zone indicates the agent was not detected, two lines (one in the control zone and one in the test zone) indicate the agent was detected. The absence of a control line indicates the assay is invalid and any positive or negative test result must be disregarded.

The management system governing the manufacture of this product is ISO 9001:2008-certified (specifies the requirements of a quality management system).

\section{Peer-Reviewed References}

Slotved, H.-C.; Tanassi, J. T.; Sparding, N.; Lindqvist, A.; Steenhard, N. R.; Heegaard, N. H. H. Botulinum Toxin Field Assays Evaluated Using Cosmetic Botox Preparations. Biosecurity and bioterrorism: biodefense strategy, practice, and science 2013, 11, 280286. DOI: 10.1089/bsp.2013.0050.

This study compared several different botulinum detection technologies using botulinum toxins (BoNTs) A and B, as well as

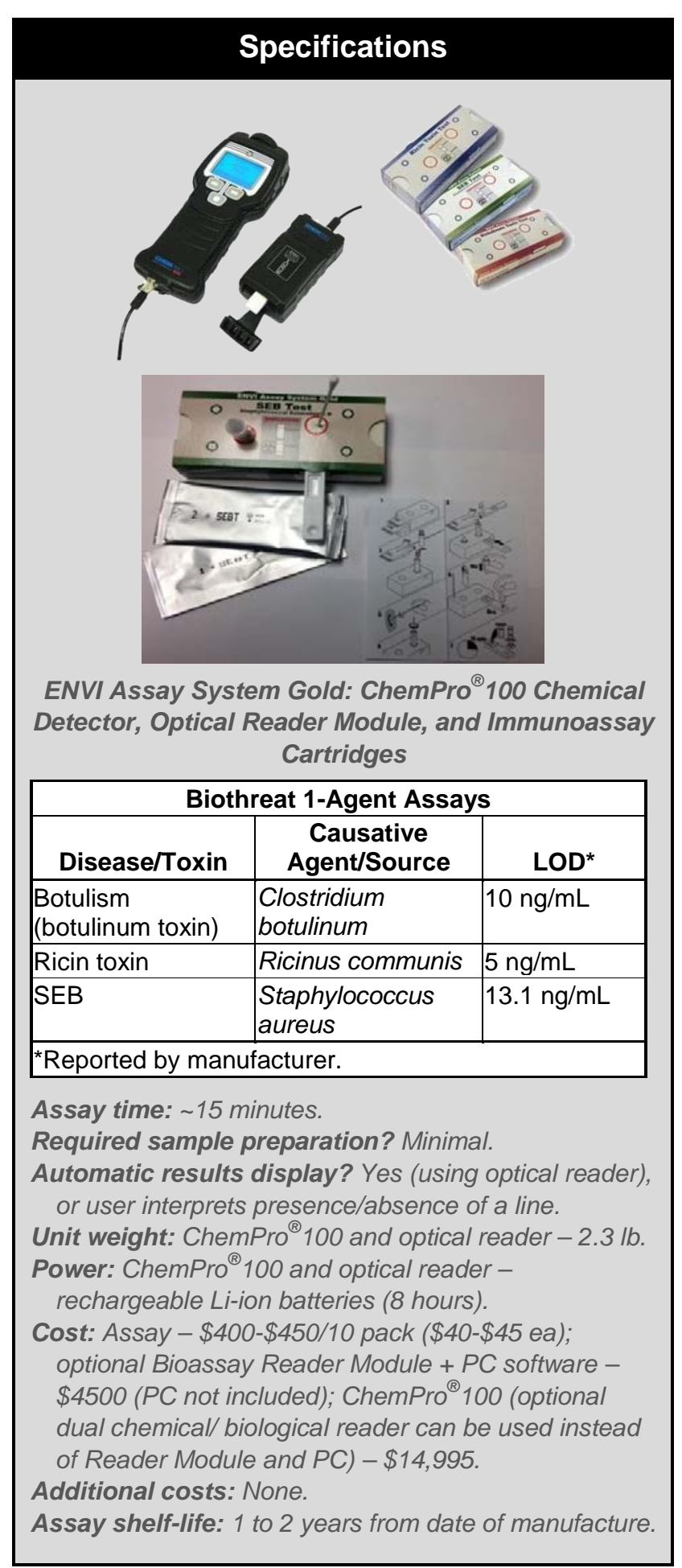


four pharmaceutical-grade cosmetic botulinum toxin preparations. An ELISA method was used as a baseline and compared to an immunoaffinity column and LFAs from AdVnt Biotechnologies (1-agent BADD $^{\mathrm{TM}}$ and 5-agent ProStrips), Environics (ENVI Assay system), and Alexeter (RAID DX kit, which contains an 8-agent RAID 8 LFA and a 3-agent RAID TOX LFA). Relatively low concentrations of BoNTs (both commercial and pharmaceutical sources) were used and were not detected by most of the LFAs. BADD ${ }^{\mathrm{TM}}$ did not detect pharmaceutical BoNT A (100 ng/mL), commercial BoNT A (50 ng/mL), or commercial BoNT B (500 ng/mL and 10,000 ng/mL). ProStrips did not detect commercial BoNT A (50 ng/mL and 10,000 ng/mL), commercial BoNT B (10,000 ng/mL), or pharmaceutical BoNT A (100 $\mathrm{ng} / \mathrm{mL})$. The ENVI Assay System gave one positive result and one negative result with commercial BoNT A (10,000 ng/mL), but did not detect pharmaceutical BoNT A (100 ng/mL and $27.5 \mathrm{ng} / \mathrm{mL})$. The RAID 8 and RAID TOX did not detect pharmaceutical BoNT A (27.5 ng/mL and $13.75 \mathrm{ng} / \mathrm{mL})$, although those concentrations are below the manufacturer stated LOD for BoNT. 


\section{GenPrime, Inc.: Toxin Screen}

Product Link: http://www.genprime.com/products_primealert_techspecs.asp

Contact: Darby McLean (dmclean@genprime.com)

Phone: (866) 624-9855 Manufacturer's website: http://www.genprime.com

\section{Technology Summary}

The immunoassay toxin test is a standard lateral flow immunoassay that contains assays to detect ricin, botulinum serotype A, and SEB in a single cartridge. The immunoassay is designed to work with the Prime Alert ${ }^{\circledR}$ DNA detection sample buffers, so both the DNA test and assay for toxins can be performed from a single solubilized sample. The kit includes buffer, a sample vial, a sampling scoop and a transfer pipette, as well as a claw sampler used for reaching into envelopes.

One line in the control zone indicates the agent was not detected, two lines (one in the control zone and one in the test zone) indicate the agent was detected. The absence of a control line indicates the assay is invalid and any positive or negative test result must be disregarded. This product is also distributed through Smiths Detection.

The management system governing the manufacture of this product is ISO 13485:2003-certified (specifies the requirements of a quality management system for medical devices).

\section{Peer-Reviewed References}

No peer-reviewed publications were found that demonstrate the use of this product for the detection of biothreat agents.

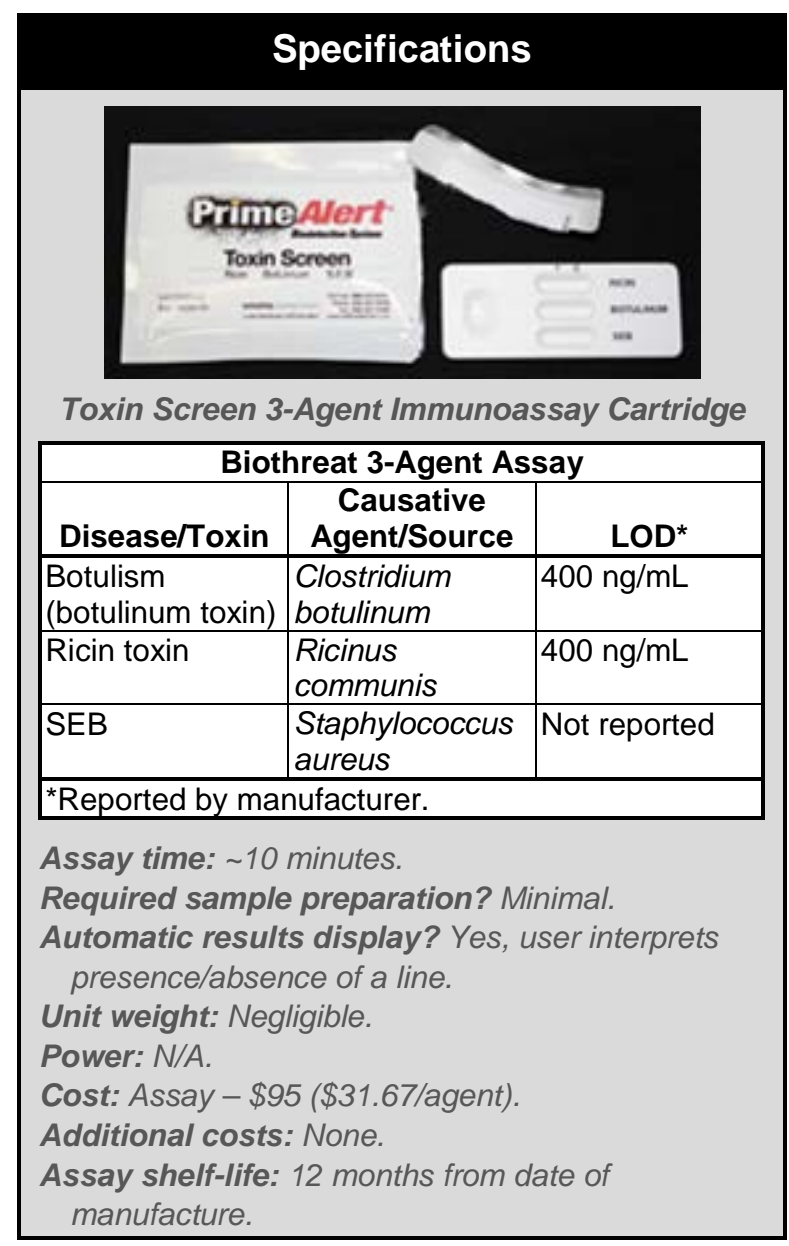




\section{New Horizons Diagnostics, Inc.: Smart ${ }^{\mathrm{TM}}-$ II}

Product Link: http://www.nhdiag.com/anthrax.shtml

Contact: Larry Loomis (larryl@nhdiag.com)

Phone: (443) 543-5755 Manufacturer's website: http://www.nhdiag.com

\section{Technology Summary}

The New Horizon Diagnostics Smart ${ }^{\mathrm{TM}}$-II is a standard LFA. Each device tests for one agent at a time. One kit contains the LFA device, plastic droppers, and "Chase” buffer. A separate collection kit (either New Horizon Diagnostics' kit or another compatible sample collection kit) must be purchased separately. If the sample contains visible debris or large particles, a sample processing kit should be used (also sold by New Horizon Diagnostics) prior to loading sample on to the LFA. The test is initiated by adding three drops $(\sim 100 \mu \mathrm{L})$ of liquid sample to the sample well on the device using the provided dropper. After waiting 3 minutes for the sample to absorb in the sample well, two drops of Chase buffer is added from the Chase buffer dropper bottle. After a 15 minute incubation, the results can be read. One line in the control zone indicates the agent was not detected, two lines (one in the control zone and one in the test zone) indicate the agent was detected. The absence of a control line indicates the assay is invalid and any positive or negative test result must be disregarded.

The company offers a cholera assay that is Food and Drug Administration (FDA) approved. They also offer immunochromatographic assays for $E$. coli and Salmonella.

\section{Peer-Reviewed References}

Peckham, G. D.; Hew, B. E.; Waller, D. F.; Holdaway, C.; Jen, M. Amperometric Detection of Bacillus Anthracis Spores: A Portable, Low-Cost Approach to the Elisa. Int. J. Electrochem. 2013, 2013, Article $803485 . \quad$ DOI: $\quad 10.1155 / 2013 / 803485$.

\begin{tabular}{|c|c|c|}
\hline \multicolumn{3}{|c|}{ Specifications } \\
\hline \multicolumn{3}{|c|}{ - $\mathrm{TT}$} \\
\hline \multicolumn{3}{|c|}{ Anthrax Spore } \\
\hline \multicolumn{3}{|c|}{ Positive } \\
\hline \multicolumn{3}{|c|}{$=\quad \frac{1}{1}$} \\
\hline \multicolumn{3}{|c|}{ Anthrax Spore } \\
\hline \\
\hline \multicolumn{3}{|c|}{ Smart $^{\mathrm{TM}}$-II 1-Agent Immunoassay Device } \\
\hline \multicolumn{3}{|c|}{ Biothreat 1-Agent Assays } \\
\hline Disease/Toxin & \begin{tabular}{|c|} 
Causative \\
Agent/Source \\
\end{tabular} & LOD* \\
\hline Anthrax & \begin{tabular}{|l|} 
Bacillus \\
anthracis
\end{tabular} & \begin{tabular}{|l|}
100,000 \\
spores/mL
\end{tabular} \\
\hline $\begin{array}{l}\text { Botulism } \\
\text { (botulinum toxin) }\end{array}$ & \begin{tabular}{|l|}
$\begin{array}{l}\text { Clostridium } \\
\text { botulinum }\end{array}$ \\
\end{tabular} & Not reported \\
\hline Plague & Yersinia pestis & Not reported \\
\hline Ricin toxin & \begin{tabular}{|l} 
Ricinus \\
communis
\end{tabular} & Not reported \\
\hline SEB & \begin{tabular}{|l|} 
Staphylococcus \\
aureus
\end{tabular} & Not reported \\
\hline Tularemia & $\begin{array}{l}\text { Francisella } \\
\text { tularensis }\end{array}$ & Not reported \\
\hline \multicolumn{3}{|c|}{${ }^{\star}$ Reported by manufacturer. } \\
\hline \multicolumn{3}{|c|}{$\begin{array}{l}\text { Assay time: } 15 \text { minutes. } \\
\text { Required sample preparation? Minimal. } \\
\text { Automatic results display? Yes, user interprets } \\
\quad \text { presence/absence of a line. } \\
\text { Unit weight: Negligible. } \\
\text { Power: N/A. } \\
\text { Cost: Assay - } \$ 550 / 25 \text { pack ( } \$ 22 \text { ea). } \\
\text { Additional costs: Sample collection supplies. } \\
\text { Assay shelf-life: } 12 \text { months from date of } \\
\text { manufacture. }\end{array}$} \\
\hline
\end{tabular}

http://www.hindawi.com/journals/ijelc/2013/803485/

This investigation compared an antibody-based method using amperometric signal generation to ELISAs and LFAs for detecting Bacillus anthracis (Sterne strain) spores. Tetracore's ELISA kit assays were used. The LFDs included BADD ${ }^{\mathrm{TM}}$, Smart ${ }^{\mathrm{TM}}$-II, and BioThreat Alert ${ }^{\circledR}$. At least 15 of each LFD were tested with spore concentrations of $10^{4} \mathrm{CFU} / \mathrm{mL}$ to $5 \times 10^{6} \mathrm{CFU} / \mathrm{mL}$. All LFDs detected $5 \times 10^{6}$ $\mathrm{CFU} / \mathrm{mL}$ in greater than $>90 \%$ of trials. Performance decreased with decreasing spore concentration 
( $<80 \%$ for $10^{6} \mathrm{CFU} / \mathrm{mL}$ and $<60 \%$ for $5 \times 10^{5} \mathrm{CFU} / \mathrm{mL}$ ). Smart ${ }^{\mathrm{TM}}$-II detected samples with $10^{5} \mathrm{CFU} / \mathrm{mL}$, but only in $<40 \%$ of trials. BioThreat Alert ${ }^{\circledR}$ was reported to be the easiest to interpret with a dark, highly contrasted test line. The readout on the $\mathrm{BADD}^{\mathrm{TM}}$ was reported to be very faint, even at high spore concentrations. ELISA had $100 \%$ positive detection for all spore concentrations, though each assay takes over 6 hours to complete. Amperometry, which required just over an hour to complete, detected spores in $>90 \%$ of trials at $>10^{5} \mathrm{CFU} / \mathrm{mL}$; however, performance decreased with decreasing spore concentration (86\% for $5 \times 10^{4} \mathrm{CFU} / \mathrm{mL}$ and $47 \%$ for $10^{4} \mathrm{CFU} / \mathrm{mL}$ ).

Sha, J.; Endsley, J. J.; Kirtley, M. L.; Foltz, S. M.; Huante, M. B.; Erova, T. E.; Kozlova, E. V.; Popov, V. L.; Yeager, L. A.; Zudina, I. V.; Motin, V. L.; Peterson, J. W.; DeBord, K. L.; Chopra, A. K. Characterization of an F1 Deletion Mutant of Yersinia pestis CO92, Pathogenic Role of F1 Antigen in Bubonic and Pneumonic Plague, and Evaluation of Sensitivity and Specificity of F1 Antigen CaptureBased Dipsticks. J. Clin. Microbiol. 2011, 49, 1708-1715. DOI. 10.1128/jcm.00064-11.

Two LFAs for the detection of Yersinia pestis were compared in this evaluation. BioThreat Alert ${ }^{\circledR}$ and Smart ${ }^{\mathrm{TM}}$-II performed similarly and were able to detect $10^{5}$ to $5 \times 10^{5} \mathrm{CFU} / \mathrm{mL}$ of the bacteria and 0.5 $\mu \mathrm{g} / \mathrm{mL}$ for purified antigen (i.e., the surface protein from the bacteria) in PBS or infected whole mouse blood. The authors note that their limits of detection were not as low as some other studies, which could be related to differences in the purity of the antigen or strains of Yersinia pestis used in the various studies.

Gessler, F.; Pagel-Wieder, S.; Avondet, M-A. Bohnel, H. Evaluation of Lateral Flow Assays for the Detection of Botulinum Neurotoxin Type A and Their Application in Laboratory Diagnosis of Botulism. Diagn. Microbiol. Infect. Dis. 2007, 57, 243-249. DOI: 10.1016/j.diagmicrobio.2006.07.017.

This study evaluated BioThreat Alert ${ }^{\circledR}$, Smart $^{\mathrm{TM}}-\mathrm{II}, \mathrm{BADD}^{\mathrm{TM}}$, and RAMP ${ }^{\circledR}$ assays for their ability to detect botulinum neurotoxin in three forms: purified botulinum neurotoxin A (BoNT/A), toxin complex, and toxin in the supernantant of a Clostridium botulinum culture. Only BADD ${ }^{\mathrm{TM}}$ and RAMP ${ }^{\circledR}$ detected purified BoNT/A; LODs were $100 \mathrm{ng} / \mathrm{mL}$ for BADD ${ }^{\mathrm{TM}}$ and $50 \mathrm{ng} / \mathrm{mL}$ for RAMP ${ }^{\circledR}$. All assays detected the BoNT/A complex, and SMARTTM-II and BioThreat Alert had greater sensitivity for the BoNT/A complex $(10 \mathrm{ng} / \mathrm{mL})$ than BADD ${ }^{\mathrm{TM}}(100 \mathrm{ng} / \mathrm{mL})$ and RAMP ${ }^{\circledR}(250 \mathrm{ng} / \mathrm{mL})$. For the Clostridium botulinum culture samples, the concentration of active toxin was estimated using a mouse lethality assay. The lowest concentration of toxin in culture medium that the Biotherat Alert ${ }^{\circledR}$, Smart ${ }^{\mathrm{TM}}$-II, and BADD ${ }^{\mathrm{TM}}$ could detect was 100 Minimal mouse Lethal Doses (MLD)/mL while RAMP ${ }^{\circledR}$ could detect only 2500 $\mathrm{MDL} / \mathrm{mL}$. BADD ${ }^{\mathrm{TM}}$ gave a false-positive result for a culture medium that did not contain Clostridium botulinum or toxin.

King, D.; Luna, V.; Cannons, A.; Cattani, J.; Amuso, P. Performance Assessment of Three Commercial Assays for Direct Detection of Bacillus anthracis Spores. J. Clin. Microbiol. 2003, 41, 3454-3455. DOI:10.1128/JCM.41.7.3454-3455.2003.

This brief study by the Florida Department of Health Laboratory evaluated three immunoassay tests including BioThreat Alert ${ }^{\circledR}$, Osborne Scientific’s $1^{\text {st }}$ generation BADD (Note: Osborne’s biothreat product line was acquired by AdVnt in 2003 and the current assay is $3^{\text {rd }}$ generation), and Smart ${ }^{\mathrm{TM}}$-II. The tests were evaluated for Bacillus anthracis (Pasteur strain) detection at concentrations ranging from $10^{2}$ to 
$10^{6}$ spores (the concentration of the test samples and volume of sample applied were not reported). Only 2 to 8 samples were tested at each concentration. All test kits could detect Bacillus anthracis at $10^{6}$ spores. BADD $^{\mathrm{TM}}$ and Smart ${ }^{\mathrm{TM}}$-II could detect $10^{5}$ spores; however, BioThreat Alert ${ }^{\circledR}$ detected $10^{5}$ spores only once in eight separate assays. None of the assays could detect fewer than 10,000 spores. Tests were allowed to develop for 15 minutes, although positive results were apparent within 5 minutes. Bacillus cereus and Bacillus thuringiensis (non-threat near neighbors that could potentially result in a falsepositive) were also tested twice for each test strip. No false positives were observed for the BADD ${ }^{\mathrm{TM}}$ or BioThreat Alert ${ }^{\circledR}$ tests; however, the Smart ${ }^{\mathrm{TM}}$-II tests yielded one false-positive result for Bacillus thuringiensis. 


\section{PathSensors, Inc.: CANARY ${ }^{\circledR}$ Zephyr}

Product Link: http:www.pathsensors.com/zephyr.html

Contact: Dan Spindler (dspindler@pathsensors.com)

Phone: (443) 557-6150 Manufacturer's website: http:www.pathsensors.com

\section{Technology Summary}

The Cellular Analysis and Notification of Antigen Risks and Yields (CANARY ${ }^{\circledR}$ ) platform is a cell-based immunoassay system. It uses specially designed cells (B cells or white blood cells) to sense and respond to defined biothreats. The B cells have been engineered to produce specific antibodies on their surface that bind the biothreat agent. Agent binding to the B cell surface triggers the release of light from a bioluminescent protein within the cell.

Following sample collection (sampling kit sold separately), the swab is placed in a tube containing the swab diluent and shaken to displace the sample from the swab. A $1 \mathrm{~mL}$ sample of the diluent is centrifuged for 2 minutes using the included micro-centrifuge and then the liquid is decanted. The sample is centrifuged again for 2 minutes, after the addition of 3 drops of assay buffer. The 'biosensor' solution (containing engineered cells) is then added to the sample tube and briefly centrifuged for 5 seconds. The result is then determined by placing the sample tube into the luminometer. Detection is sensitive and fast; following sample collection, as few as $100 \mathrm{CFU} / \mathrm{PFU}$ of pathogen can be detected in 5 minutes. The LOD is ultimately determined by the affinity of the agent-specific antibody.

Assays are also available for Salmonella and Listeria species. The CANARY ${ }^{\circledR}$ Zephyr platform is currently in use at some USDA, FDA, and Department of Defense (DoD) locations, as well as some State Health Departments. Limited performance testing has been performed by Battelle in Columbus, Ohio.

\section{Peer-Reviewed References}

Rider, T. H.; Petrovick, M. S.; Nargi, F. E.; Harper, J. D.; Schwoebel, E. D.; Mathews, R. H.; Blanchard, D. J.;

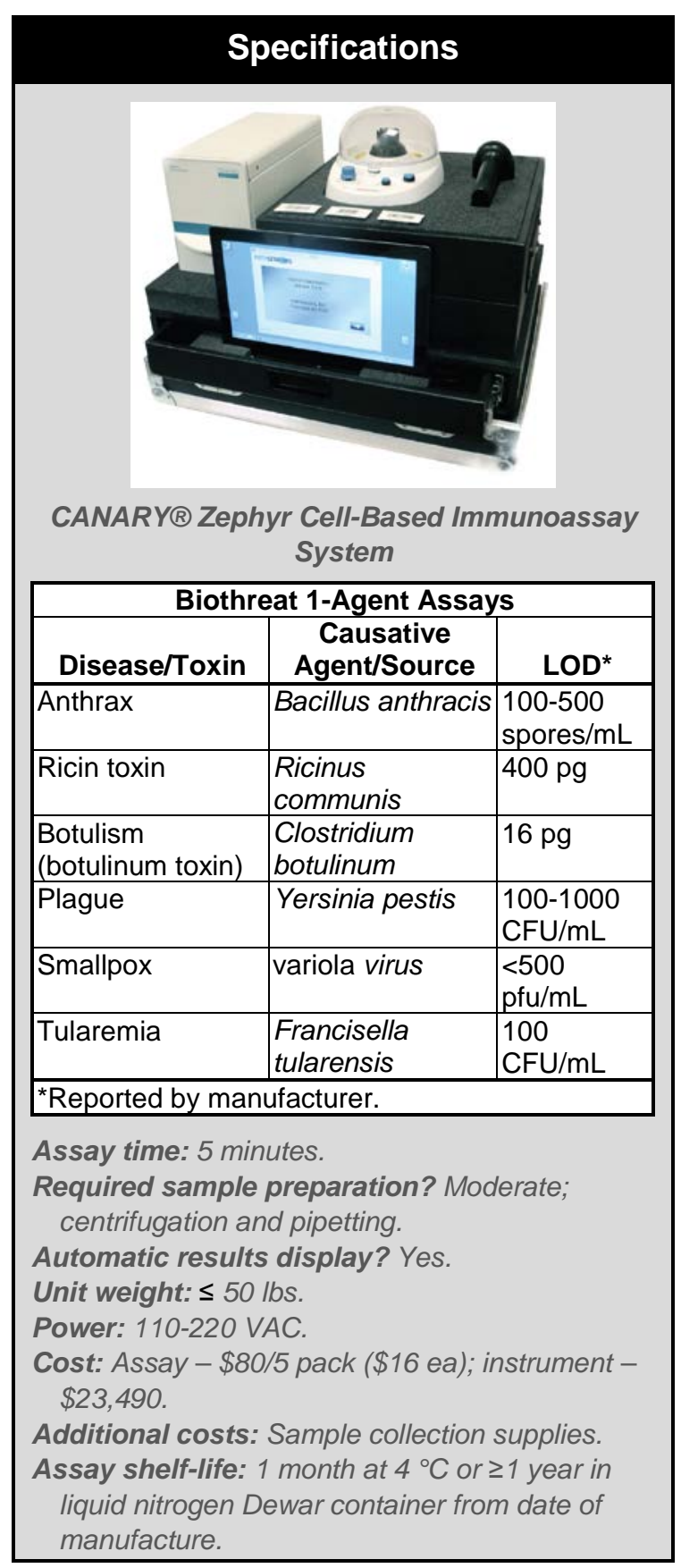

Bortolin, L. T.; Young, A. M.; Chen, J.; Hollis, M. A. A B Cell-Based Sensor for Rapid Identification of Pathogens. Science 2003, 301, 213-215. DOI:10.1126/science.1084920.

This report describes the fundamental principles of the CANARY ${ }^{\circledR}$ detection approach used in the Zephyr system. First published in 2003, the detection approach remains fundamentally unchanged; however, the instrument platform (i.e., the Zephyr) has evolved into a system that is suitable for certain 
field deployments (e.g., mobile laboratories), and the assay sensitivity has improved. The detection principle utilizes B cells (lymphocytes) that have been engineered to express a calcium-sensitive bioluminescent protein that emits light when exposed to specific bacteria and viruses. The B cells contain membrane-bound antibodies to enable specific biothreat recognition. Upon cross-linking of the antibodies by specific bacteria or viruses, a rapid elevation of intracellular calcium concentration in the B cells occurs, resulting in the emission of light that is detected by a luminometer. 


\section{QTL Biodetection, LLC: BIOSENSOR ${ }^{\mathrm{TM}}$ 2200R}

Product Link: http://us.msasafety.com/CBRNE-Detectors/CBRNE-Detectors/BIOSENSOR\%26trade\%3B-2200R-BiologicalAgent-Detector/p/000400000400001000

Contact: Brian Oswalt at QTL or (info.us@msasafety.com)

Phone: (724) 575-0033 Distributor's website: http://us.msasafety.com/

\section{Technology Summary}

The BIOSENSOR ${ }^{\mathrm{TM}}$ 2200R (developed by QTL Biosystems and sold in the United States by MSA) is an automated fluorescence-based immunoassay system. A red-light/green-light (threat present/absent) result is delivered in 5 minutes. The assay protocols are set up for powder samples, but wet samples may also be analyzed. Each disposable assay cartridge kit comes with a sample collection swab, a sample vial, and syringes for sample and wash buffer delivery into the assay cartridge. Once a sample and wash buffer are injected into the cartridge, the user shakes the cartridge manually for 1 minute to dissolve the detection reagents (i.e., a pair of antibodies that both bind to the agent). One antibody has a fluorescence label for optical detection and the other has a magnetic bead attached for immobilization on the sensor. A complex is formed between the antibodies and biothreat agent in solution, and then a magnetic field is applied to concentrate the magnetic beads and antibody-threat agent complexes into a pellet on the sensing surface. After the pellet is formed, the operator is prompted to depress the wash syringe plunger to remove any potentially interfering materials before the fluorescence is read. Protocols for sample processing are laminated inside the lid of the IP67 rated housing/Pelican ${ }^{\mathrm{TM}}$ case and the instrument prompts the operator at each step in the process. To verify a positive result, the sample must also be analyzed using a negative control cartridge. Likewise, to verify a negative result, a positive control cartridge must also be analyzed.

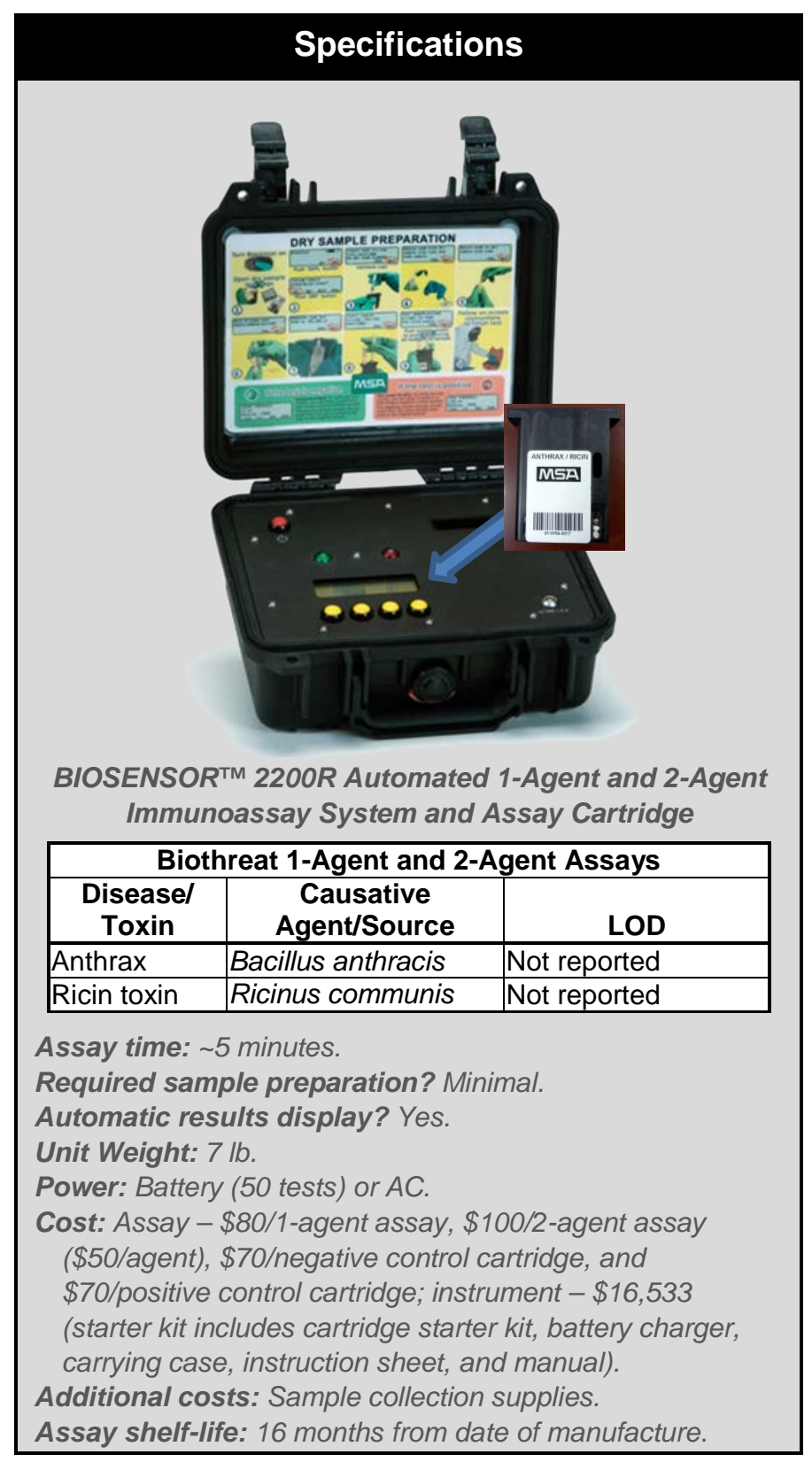

MSA sells assay cartridges according to plans designed for low-volume (1 call per 2 months), medium-volume ( 2 calls per month), and high-volume (5 calls per month) usage. As an example, the lowvolume plan includes: six anthrax/ricin toxin 2-agent assays, two anthrax and two ricin toxin 1-agent assays, six positive control cartridges, two negative control cartridges, two calibration kits, and two wet 
sample kits. Although a calibration kit is available, MSA/QTL maintains it is not necessary and the instrument light sources (light emitting diodes) are stable for 100,000 hours of use.

\section{Peer-Reviewed References}

No peer-reviewed publications were found that demonstrate the use of this product for the detection of biothreat agents. 


\section{Research International, Inc.: BioHawk ${ }^{\circledR}$}

Product Link: http://resrchintl.com/Biohawk_Bioidentification_System.html

Contact: David McCrae (davidmccrae@resrchintl.com)

Phone: (360) 805-4930 Manufacturer's website: http://www.resrchintl.com

\section{Technology Summary}

The BioHawk $^{\circledR}$ is a portable, automated aerosol collector with integrated automated 8-channel immunoassay detection. In addition to biological agents, it can be configured to detect explosives and chemical agents with appropriately selected assay coupons. The device can be programmed to collect air samples for a predetermined time followed by automated sample processing and detection.

The air sampler is a multi-stage wetted-wall cyclone that collects air at 325 liters per minute and transfers the particulates and aerosols to a liquid phase concentrate that is then periodically transferred to the assay coupon and detector using automated pumps and valves. A portion of the collected concentrate can also be automatically delivered to a storage vessel for archiving or additional analyses.

Assays are performed in a credit card-sized plastic assay coupon which can be used for up to 24 hours to analyze as many as 10 samples (if no positive results are obtained) before being discarded. If the system and coupon are kept refrigerated, it can be used for up to 48 hours.

Results are displayed on the touch panel LCD and can be accompanied by an audible alarm or pulsating light. Results can be transmitted wirelessly and the system can be operated remotely.

The system is easy to use as the internal processes and steps are preset using built-in computerized recipes. Optional Windows-based software can also be used to develop customized sample collection, processing, and detection protocols.

Additional assays can be developed for custom orders. Reported assay sensitivities have been gathered from various third-party research groups and are not guaranteed by Research International.

\section{Peer-Reviewed References}

No peer-reviewed publications were found that demonstrate the use of this product for the detection of biothreat agents.

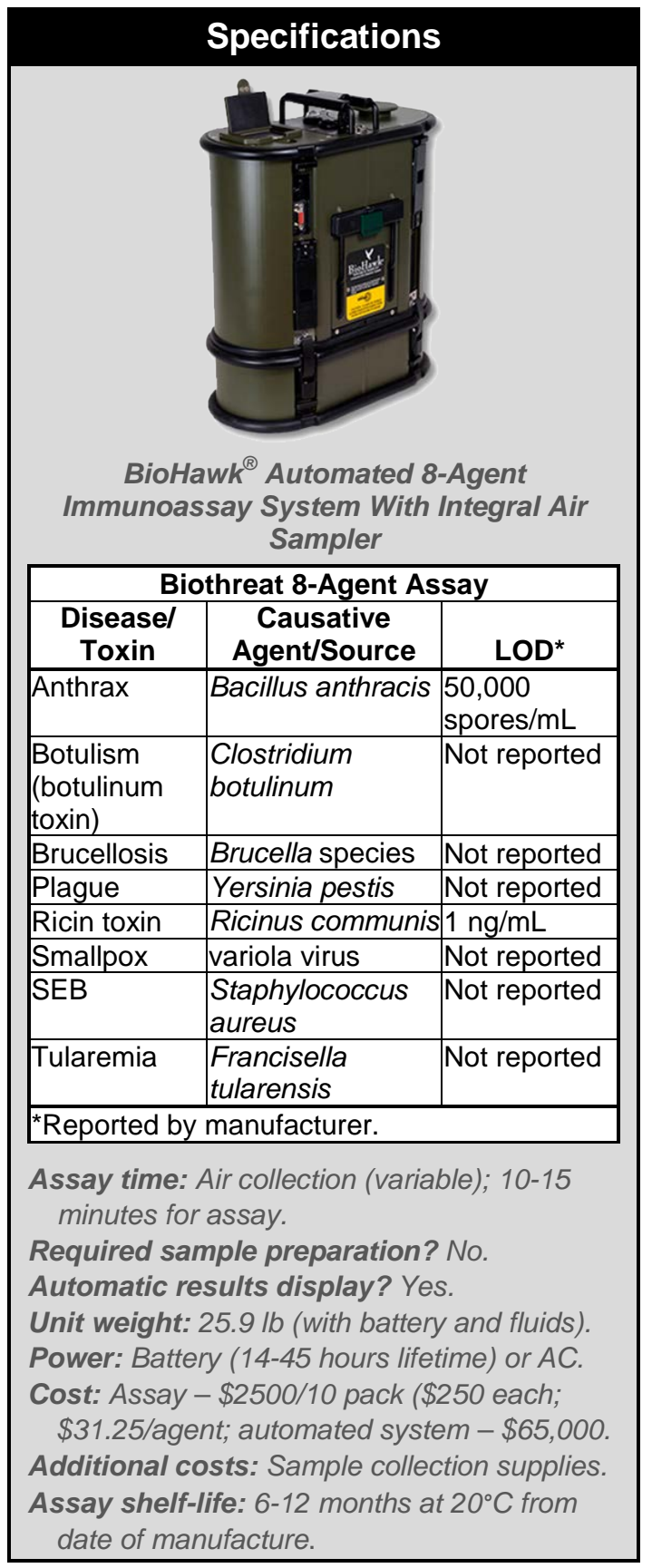

Specifications

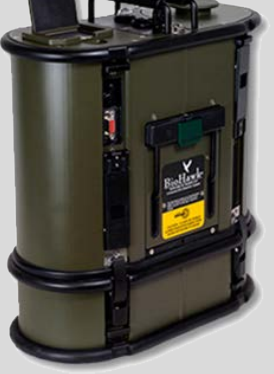
Sample 


\section{Research International, Inc.: RAPTOR ${ }^{\mathrm{TM}}$}

Product Link: http://resrchintl.com/RAPTOR_4-Channel_Bioassay.html

Contact: David McCrae (davidmccrae@resrchintl.com)

Phone: (360) 805-4930 Manufacturer's website: http://www.resrchintl.com

\section{Technology Summary}

The RAPTOR ${ }^{\mathrm{TM}}$ is a portable automated assay system first introduced in 2000. It can be configured to detect a wide range of analytes including biological agents, toxins, explosives, and chemicals using antibody-based assay coupons. The RAPTOR ${ }^{\mathrm{TM}}$ is an automated sample processing system and fluorescence optical reader with integrated fluidics, electronics, and software, which uses proprietary disposable optical waveguide coupons. The system is highly configurable and the user can define multi-step assay protocols and develop their own sample processing and assay protocols and assay coupons. There are also a range of pre-defined assay protocols and coupons for biothreat agents. Sample collection supplies must be purchased separately.

The disposable assay coupons are about the size of a credit card and contain four reaction surfaces (i.e., channels containing sensor elements/waveguides) that can be used to simultaneously detect four different biothreat agents. The assay coupons can be functionalized by the user or purchased preconfigured. The pre-configured assay coupons contain a barcode that is automatically read by the instrument and sets up the run parameters for the assay. The system delivers the sample to the reaction surface, which has an immobilized antibody that captures the agent on the surface. Then the system can be configured for a wash step (to remove unbound material) before a second fluorescently labeled antibody, specific for the agent, is automatically delivered to the surface. To run an assay, the user adds buffer to the detection antibody (supplied dried in a vial), connects the vial to the system, adds $1 \mathrm{~mL}$ of liquid sample to the assay coupon, inserts the assay coupon into the automated system, and

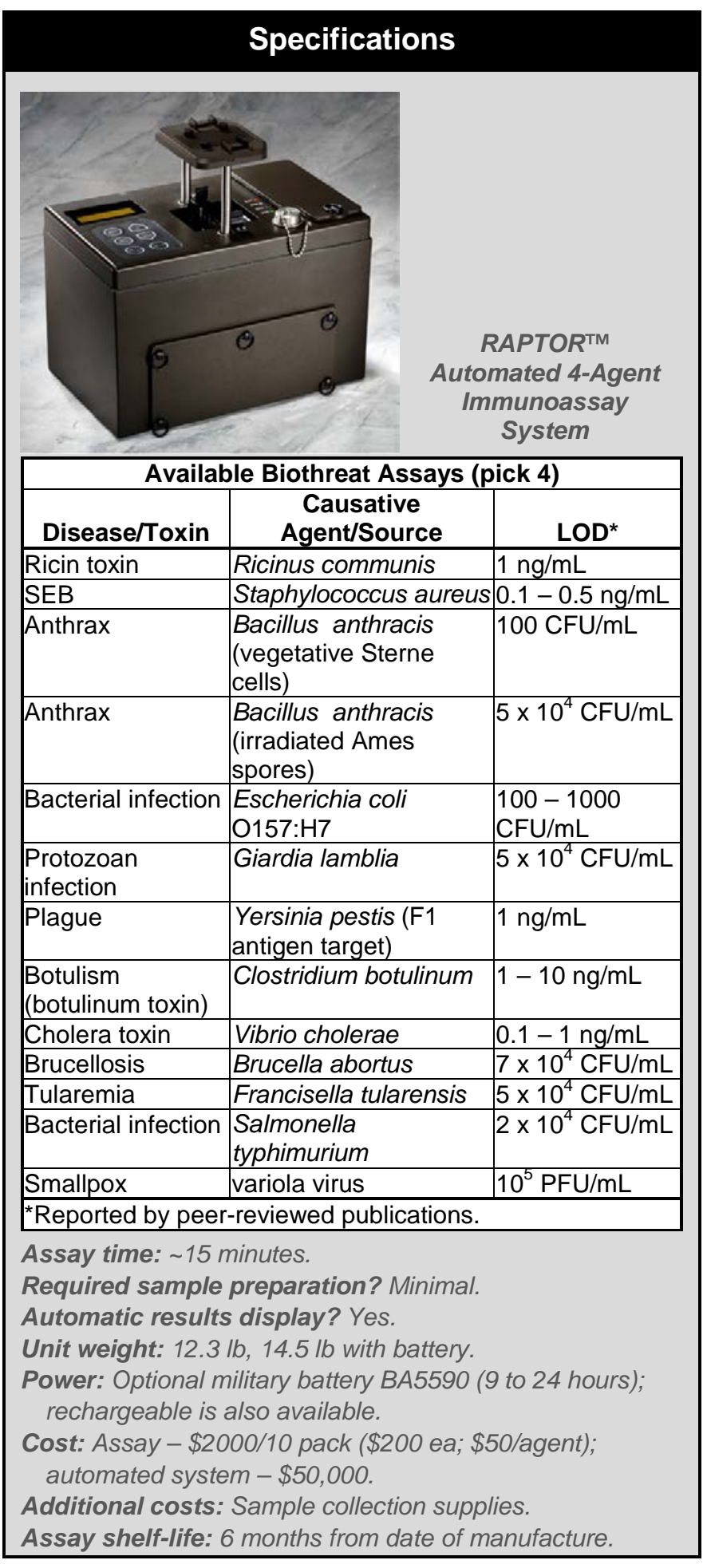


presses the "Run Assay” key. For all assays, the first run performed daily must be a 'blank' assay to set the baseline. Each assay, including the initial blank run, takes 10 to 15 minutes to complete. If an assay is negative, the coupon can be reused in an 8- to 12-hour period for up to 30 assays or until a positive result is obtained.

\section{Peer-Reviewed References}

Kim, G-Y.; Morgan, M. T.; Ess, D.; Hahm, B-K; Kothapalli, A.; Valadez, A.; Bhunia, A. Detection of Listeria Monocytogenes Using an Automated Fiber Optic Biosensor: RAPTOR. Key Eng. Mater. 2006, 321-323, 1168-1171. DOI: 10.4028/www.scientific.net/KEM.321-323.1168.

This report by researchers at Purdue University and the Korean Institute of Agricultural Engineering describes the development of RAPTOR ${ }^{\mathrm{TM}}$ for the detection of Listeria monocytogenes. Pre-incubating the sample with the detection antibody for 30 minutes increased the sensitivity of the assay. The sensitivity of the assay for Listeria monocytogenes cultured 20 hours from a spiked hotdog sample was $5.4 \times 10^{7}$ $\mathrm{CFU} / \mathrm{mL}$.

Viswaprakash, N.; Kim, G.; Morgan, M. T.; Ess, D.; Hahm, B-K.; Kothapalli, S.; Valadez, A.; Geng, T.; Bhunia, A. K. Antibody Immobilization on Waveguides Using a Flow-Through System Shows Improved Listeria monocytogenes Detection in an Automated Fiber Optic Biosensor: RAPTOR ${ }^{\mathrm{TM}}$. Sensors 2006, 6, 808-822. DOI: 10.3390/s6080808. http://www.mdpi.com/1424-8220/6/8/808/pdf (accessed Feb 25, 2014).

This report by researchers at Purdue University and the Korean Institute of Agricultural Engineering describe the development of RAPTOR ${ }^{\mathrm{TM}}$ for the detection of Listeria monocytogenes. The developed sandwich immunoassay used a polyclonal antibody to capture Listeria monocytogenes from the sample and a monoclonal antibody to detect the captured Listeria monocytogenes. The optimized assay could detect $10^{3} \mathrm{CFU} / \mathrm{mL}$ Listeria monocytogenes in PBS. In samples cultured from frankfurters spiked with Listeria monocytogenes, $5 \times 10^{5} \mathrm{CFU} / \mathrm{mL}$ Listeria monocytogenes could be detected. Negative control cultures of Listeria rhamnosus and Enterococcus faecalis also showed increasing signal with increasing concentration; however, they were at a lower level than the comparative signals with Listeria monocytogenes. Thus, samples containing relatively high concentrations of Listeria rhamnosus or Enterococcus faecalis could be interpreted as containing a low concentration of Listeria monocytogenes.

Jung, C. C.; Saaski, E. W.; McCrae, D. A.; Lingafelt, B. M.; Anderson, G. P. RAPTOR: A Fluoroimmunoassay-Based Fiber Optic Sensor for Detection of Biological Threat. IEEE Sens. J. 2003, 3, 352-360. DOI: 10.1109/JSEN.2003.815775.

This report by researchers at Research International, George Mason University, and the U.S. Naval Research Laboratory describes the RAPTOR ${ }^{\mathrm{TM}}$ in detail and summarizes improvements in hardware and assay chemistry that result in approximately a log-order improvement over the previous system. While this study reported increases in assay signal for each improvement, the authors state this translated to improvements in the LOD for RAPTOR ${ }^{\mathrm{TM}}$; however, results are not provided to support this statement. The report also briefly summarized an unpublished trial of the system conducted in June 2002 in which 17 of 17 samples containing $10^{5}$ spores/mL Bacillus anthracis were detected when interspersed between 132 negative samples. In a similar trial in April 2001, the system's predecessor only detected 1 of 16 samples containing $10^{5}$ spores/mL Bacillus anthracis interspersed between 256 negative samples. 
Anderson, G. P.; Nerurkar, N. L. Improved Fluoroimmunoassays Using the Dye Alexa Fluor 647 with the RAPTOR, a Fiber Optic Biosensor. J. Immunol. Methods, 2002, 271, 17-24. DOI: 10.1016/S00221759(02)00327-7.

This report by researchers at the U.S. Naval Research Laboratory investigates the performance of the fluorescent dye Alexa Fluor 647 compared to Cy5 when used in immunoassays on the RAPTOR ${ }^{\mathrm{TM}}$ system. In both a direct binding immunoassay for ricin and a sandwich assay for Staphylococcal enterotoxin B, the Alexa Fluor 647-labeled antibodies produced higher fluorescence signals than the Cy5labeled antibodies. Higher signal intensity should translate to assays with increased sensitivities; however, this was not demonstrated in the scope of this study. 


\section{Response Biomedical Corp.: RAMP ${ }^{\circledR}$}

Product Link: http://responsebio.com/biodefense

Contact: Sarah Wylie (customersupport@responsebio.com)

Phone (604) 456-6010 ((866) 525-7267 or (604) 219-619 for Technical Support)

Manufacturer's website: www.responsebio.com

\section{Technology Summary}

The Rapid Analyte Measurement Platform $\left(\right.$ RAMP $\left.^{\circledR}\right)$ is a fluorescence-based LFA system. The test uses a fluorescence-based detection scheme that requires an optical reader. Each RAMP $^{\circledR}$ test kit includes 25 test cartridges with test tips, 25 sample vials, 25 powder-sampling microbrushes, 10 liquid sampling swabs, 1 transfer device, a marker pen, and an instruction card. The optical reader includes a waterproof Pelican ${ }^{\mathrm{TM}}$ case and an integral printer. Four test kits are available. Sample preparation for this test is slightly more involved than a standard colorimetric LFA; however, the test is more sensitive than standard LFAs. Initial swab sampling follows standard methods (i.e., swab and solubilize in sample buffer). However, transferring the sample to the assay cartridge involves first mixing with the dye-labeled detection antibody, which is dried in the transfer pipette tip. The operator must slowly depress and release the plunger ten times and check that the sample is fully mixed by confirming that the pink dot is no longer visible on the inside of the tip. Once the sample is mixed, the test proceeds like a typical LFA (i.e., add sample to sample window, insert into the fluorescence optical reader, and incubate for 15 minutes). As with standard LFAs, RAMP ${ }^{\circledR}$ has an internal positive control, which is automatically read by the system and used for signal processing and quality control when analyzing and displaying

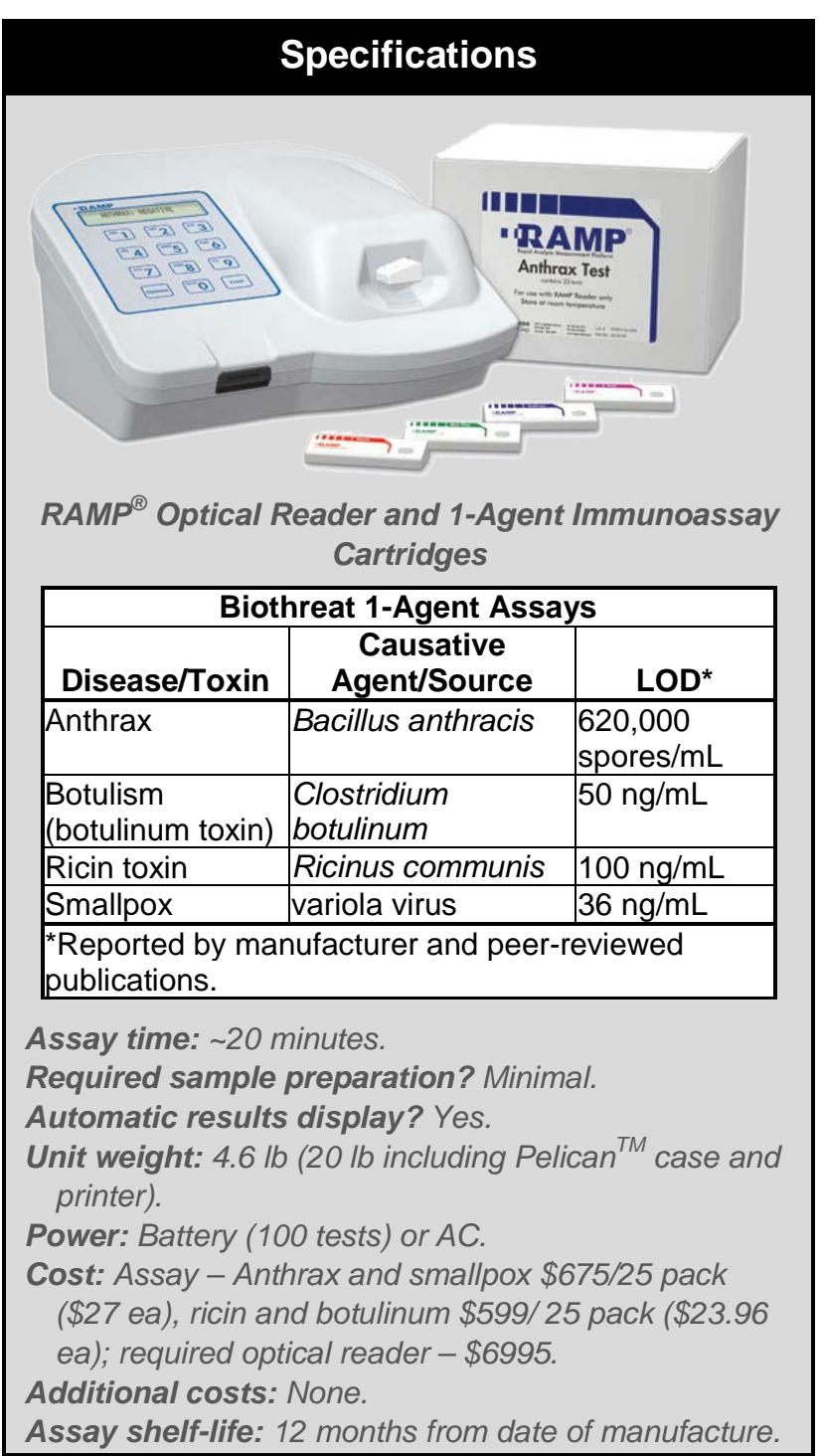
the results. Unlike standard LFAs, the positive control that is incorporated into the proprietary RAMP Ratio $^{\circledR}$ corrects for variability in operator technique, sample volume, environmental conditions, and sample viscosity.

The RAMP $^{\circledR}$ anthrax test is the first commercial handheld anthrax test that has a "Performance Tested Status” issued from the AOAC Research Institute. The initial performance evaluation was performed in 2004, and the assay has been recertified annually since then as "performing to the manufacturer's specifications."

The management system governing the manufacture of this product is ISO 9001:2008-certified (specifies the requirements of a quality management system) and ISO 13485:2003-certified (specifies the requirements of a quality management system for medical devices). 


\section{Peer-Reviewed References}

Gessler, F.; Pagel-Wieder, S.; Avondet, M-A. Bohnel, H. Evaluation of Lateral Flow Assays for the Detection of Botulinum Neurotoxin Type A and Their Application in Laboratory Diagnosis of Botulism. Diagn. Microbiol. Infect. Dis. 2007, 57, 243-249. DOI: 10.1016/j.diagmicrobio.2006.07.017.

This study evaluated BioThreat Alert ${ }^{\circledR}$, Smart ${ }^{\mathrm{TM}}-\mathrm{II}, \mathrm{BADD}^{\mathrm{TM}}$, and RAMP ${ }^{\circledR}$ assays for their ability to detect botulinum neurotoxin in three forms: purified botulinum neurotoxin A (BoNT/A), toxin complex, and toxin in the supernantant of a Clostridium botulinum culture. Only BADD ${ }^{\mathrm{TM}}$ and RAMP ${ }^{\circledR}$ detected purified BoNT/A; LODs were $100 \mathrm{ng} / \mathrm{mL}$ for BADD ${ }^{\mathrm{TM}}$ and $50 \mathrm{ng} / \mathrm{mL}$ for RAMP ${ }^{\circledR}$. All assays detected the BoNT/A complex, and SMART ${ }^{\mathrm{TM}}$-II and BioThreat Alert had greater sensitivity for the BoNT/A complex $(10 \mathrm{ng} / \mathrm{mL})$ than BADD ${ }^{\mathrm{TM}}(100 \mathrm{ng} / \mathrm{mL})$ and $\mathrm{RAMP}^{\circledR}(250 \mathrm{ng} / \mathrm{mL})$. For the Clostridium botulinum culture samples, the concentration of active toxin was estimated using a mouse lethality assay. The lowest concentration of toxin in culture medium that the Biotherat Alert ${ }^{\circledR}$, Smart ${ }^{\mathrm{TM}}$-II, and BADD ${ }^{\mathrm{TM}}$ could detect was 100 Minimal mouse Lethal Doses (MLD)/mL, while RAMP ${ }^{\circledR}$ could detect only 2500 $\mathrm{MDL} / \mathrm{mL}$. BADD ${ }^{\mathrm{TM}}$ gave a false-positive result for a culture medium that did not contain Clostridium botulinum or toxin.

Hoile, R.; Yuen, M.; James, G.; Gilbert, G. L. Evaluation of the Rapid Analyte Measurement Platform $\left(\right.$ RAMP $^{\circledR}$ ) for the Detection of Bacillus anthracis at a Crime Scene. Forensic Sci. Int. 2007, 171, 1-4. DOI: 10.1016/j.forsciint.2006.09.004.

This study investigated the accuracy and reliability of RAMP ${ }^{\circledR}$ for anthrax detection. To determine sensitivity, a clinical isolate of Bacillus anthracis was measured at six concentrations and detected in all three samples at $6.2 \times 10^{5}$ spores $/ \mathrm{mL}$ (and higher concentrations) and in one of three samples at $5.1 \times 10^{5}$ spores $/ \mathrm{mL}$. Concentrations $<4.8 \times 10^{5}$ spores $/ \mathrm{mL}$ were not detected. Bacillus anthracis vegetative cells were detected at $10^{8} \mathrm{CFU} / \mathrm{mL}$, but lower concentrations were not analyzed. Specificity was determined by measuring Bacillus subtilis, Bacillus thuringiensis and Bacillus cereus spores at concentrations ranging from $10^{4}$ to $10^{10}$ spores/mL in duplicate with no false-positive results. Eleven household powders were also tested in triplicate at a concentration of 0.1 gram/liter with no false-positive results.

Harper, B.; Robinson, M. Method Modification (2004.08) to Field-Testing of Visible Powders on a Variety of Nonporous Environmental Surfaces: Field Study. J. AOAC Int. 2006, 89, 1622-1628. http://64.207.184.223/uploads/publications/Anthrax - Harper Robinson (Dugway) 2006.pdf (accessed Feb 28, 2014).

This paper provides a summary of RAMP ${ }^{\circledR}$ anthrax field-testing (conducted in a trailer) performed by six teams of first responders and civil support teams in Class $C$ personal protective equipment. Each team consisted of 3 people with all but 1 team rotating the roles of team members among sampler, facilitator, and $\mathrm{RAMP}^{\circledR}$ operator, resulting in 14 different team members operating the RAMP ${ }^{\circledR}$. Bacillus anthracis (Sterne strain) and Bacillus thuringiensis (Kurstaki) visible powder samples were collected from seven nonporous surfaces (i.e., plastic, stainless steel, ceramic tile, wood, rubber, sealed concrete, and foodgrade painted wood) and solubilized/processed according to the RAMP ${ }^{\circledR}$ test instructions. A total of 1008 samples were analyzed. Eight incidences of errors or invalid results occurred, but sampling and analysis were repeated with the correct results. A total of 840 Bacillus anthracis samples were analyzed, resulting in 831 true positive results and 9 false-negative results. A total of 168 Bacillus thuringiensis samples were analyzed resulting in 165 true negative results and 3 false-positive results. Because the study included 
sampling, and sample processing and detection, the unexpected results and errors could be due to sampling or procedural/processing errors and not necessarily assay or instrument errors.

Stephenson, J. RAMP ${ }^{\circledR}$ Anthrax Test Cartridge. J. AOAC Int. 2005. 88, 202-203.

This article summarizes the protocol for using RAMP $^{\circledR}$ for presumptive laboratory detection of Bacillus anthracis spores in environmental samples. No test data are reported. 


\section{Tetracore, Inc.: BioThreat Alert ${ }^{\circledR}$ Reader MX}

Product Link: http://www.tetracore.com/bio-warfare/

Contact: Ashley Bottomly (abottomly@tetracore.com)

Phone: (240) 268-5400 Manufacturer's website: http://www.tetracore.com

\section{Technology Summary}

Tetracore BioThreat Alert ${ }^{\circledR}$ Test Strips are standard 1-agent LFAs. Each BioThreat Alert ${ }^{\circledR}$ kit (containing 25 test strips) comes with 5 sample collection swabs, 5 sample vials, and $12 \mathrm{~mL}$ of buffer. Once a sample is collected and solubilized, the user applies 5 drops $(\sim 150 \mu \mathrm{L})$ of sample to the test strip sample window. After a 15-minute incubation period, the results can be read by eye in the test window. One line in the control zone indicates the agent was not detected, two lines (one in the control zone and one in the test zone) indicates the agent was detected. The absence of a control line indicates the assay is invalid, and any positive or negative test result must be disregarded.

For increased accuracy and sensitivity, an optional optical reader is available. The optical reader, which includes an optional attached stylus, is essentially a tablet-sized, handheld, touchscreen device that provides an objective interpretation of the test results. Following the test strip incubation period, it takes approximately 20 seconds for the optical reader to analyze a test strip and give an output of positive, negative, or inconclusive. The optical reader saves and prints the test results, and also includes an attached optional stylus. The Reader also has Bluetooth and Wi-Fi capabilities

\section{Peer-Reviewed References}

Ramage, J. G.; Prentice, K. W.; Marse, S. A.; Carter, A. J. Datta, S.; Drumgoole, R.; Gargis, S. R.; Griffin-Thomas, L.; Hastings, R.; Masri, H. P.; Reed, M. S.; Sharma, S. K.; Singh, A. K.; Swaney, E.; Swanson, T.; Gauthier, C.; Toney, D.; Pohl, J.; Shakamuri, P.; Stuchlik, O.; Elder, I. A.; Estacio, P. L.; Garber, E. A. E.; Hojvat, S.; Kellogg, R. B.; Kovacs, G.; Stanker, L.; Weigel, L.; Hodge, D. R.; Pillai, S. P. Comprehensive

\begin{tabular}{|c|c|c|}
\hline \multicolumn{3}{|c|}{ Specifications } \\
\hline BioThr & $\begin{array}{l}\text { BioThreat Alert }{ }^{\circledR} \text { Reade } \\
\text {-Agent Immunoassay }\end{array}$ & $\begin{array}{l}\text { L and } \\
\text { LFAs }\end{array}$ \\
\hline \multicolumn{3}{|c|}{ Biothreat 1-Agent Assays } \\
\hline $\begin{array}{l}\text { Diseasel } \\
\text { Toxin }\end{array}$ & $\begin{array}{c}\text { Causative } \\
\text { Agent/Source }\end{array}$ & LOD* \\
\hline Abrin Toxin & Abrus precatorius & $10-20 \mathrm{ng} / \mathrm{mL}$ \\
\hline Anthrax & Bacillus anthracis & $\begin{array}{l}\text { 10,000-1 million } \\
\text { CFU/mL }\end{array}$ \\
\hline $\begin{array}{l}\text { Botulism } \\
\text { (botulinum } \\
\text { toxin) } \\
\end{array}$ & $\begin{array}{l}\text { Clostridium botulinum } \\
\text { serotypes } A \text { and } B\end{array}$ & $\begin{array}{l}5-20 \mathrm{ng} / \mathrm{mL}(\mathrm{A}) \\
25-50 \mathrm{ng} / \mathrm{mL}(\mathrm{B})\end{array}$ \\
\hline Brucellosis & Brucella species & $1-2 \mu \mathrm{g} / \mathrm{mL}$ \\
\hline Plague & Yersinia pestis & $\begin{array}{l}\text { 100,000-1 million } \\
\text { CFU/mL }\end{array}$ \\
\hline Ricin toxin & Ricinus communis & $2-5 \mathrm{ng} / \mathrm{mL}$ \\
\hline SEB & Staphylococcus aureus & $5-10 \mathrm{ng} / \mathrm{mL}$ \\
\hline Smallpox & variola virus & $\begin{array}{l}40 \text { million-100 } \\
\text { million CFU/mL }\end{array}$ \\
\hline Tularemia & Francisella tularensis & $\begin{array}{l}30,000-400,000 \\
\text { CFU/mL }\end{array}$ \\
\hline \multicolumn{3}{|c|}{$\begin{array}{l}{ }^{\star} \text { Reported by manufacturer and peer-reviewed } \\
\text { publications. }\end{array}$} \\
\hline \multicolumn{3}{|c|}{$\begin{array}{l}\text { Assay time: } 15 \text { minutes. } \\
\text { Required sample preparation? Minimal. } \\
\text { Automatic results display? Yes (using optical reader), } \\
\text { or user interprets presence/absence of a line. } \\
\text { Unit weight: Reader }-2.86 \mathrm{lb} \text {. } \\
\text { Power: Not required; optional optical reader has } \\
\text { rechargeable battery (6 hours). } \\
\text { Cost: Assay - } \$ 605 / 25 \text { pack ( } \$ 24.20 \text { ea); optional optical } \\
\text { reader - } \$ 5500 \text {. } \\
\text { Additional costs: Sample collection supplies. } \\
\text { Assay shelf-life: } 2 \text { years for abrin and ricin toxin assays, } \\
3 \text { years for all others from date of manufacture. }\end{array}$} \\
\hline
\end{tabular}


Laboratory Evaluation of a Specific Lateral Flow Assay for the Presumptive Identification of Abrin in Suspicious White Powders and Environmental Samples. Biosecurity and Bioterrorism: Biodefense Strategy, Practice, and Science 2014, 12, 49-62. DOI: 10.1089/bsp.2013.0080.

A comprehensive laboratory evaluation of BioThreat Alert ${ }^{\circledR}$ abrin test strips was conducted at five test sites to assess sensitivity, specificity, reproducibility, and limitations. Tests were conducted using $150 \mu \mathrm{L}$ of sample and read both visually and with the BioThreat Alert ${ }^{\circledR}$ Reader. A total of 156 negative controls and 40 positive controls were run at the test sites during the course of the study with all samples producing expected results. Repeatability was assessed by measuring 240 abrin samples (120 at $25 \mathrm{ng} / \mathrm{mL}$ and 120 at $50 \mathrm{ng} / \mathrm{mL}$ ) performed by 10 operators at the 5 sites on at least 2 different days. All visual readings resulted in a true positive result. Optical reader values for the abrin samples at $25 \mathrm{ng} / \mathrm{mL}$ (436 \pm $95)$ and $50 \mathrm{ng} / \mathrm{mL}(698 \pm 168)$ were significantly different. An inclusivity panel was prepared from the seeds of 11 cultivars of Abrus precatorius and tested at a final protein concentration of $1 \mu \mathrm{g} / \mathrm{mL}$. All results were positive. Another panel was created from the seeds or leaves of 35 near neighbors of Abrus precatorius at a concentration of $10 \mu \mathrm{g} / \mathrm{mL}$. All of the near-neighbor samples gave negative results, except one. Abrus laevigatus gave a false-positive result at all five test sites. A panel of 65 lectins was also tested at $5 \mu \mathrm{g} / \mathrm{mL}$. All results were negative. A toxin/protein panel consisting of 11 proteins at 1 $\mu \mathrm{g} / \mathrm{mL}$ was also tested for the potential to generate false-positive results. Only ricin A and B chain proteins, which by themselves are not health threats, gave false-positive results, but not other forms of ricin. It was determined that these false-positive results could be eliminated by the addition of powdered milk to the sample buffer, although this caused a reduction in assay sensitivity. Abrin agglutinin (APA-1), which is also present in Abrus precatorius seeds but has $\sim 250$-fold lower toxicity than abrin, also gave a positive result. A white powder panel, consisting of 26 white powders commonly encountered in the field by first responders, was also tested. Powders were vortex-mixed in buffer (concentration not stated), allowed to settle for 5 minutes, and the supernatant was analyzed. A total of 18 of the powder suspensions produced a clear supernatant after settling, while 8 suspensions remained opaque. After the 15-minute assay development time, none of the white powders were found to interfere with the development of the positive control line and none gave a positive result for the presence of abrin. The powder suspensions were then tested after spiking (spiking volume not stated) with Abrus precatorius seed extract (10 $\mu \mathrm{g} / \mathrm{mL}$ ). All but one assay produced a positive sample result at all five test sites. Most of the powder did give reduced readings on the optical reader, with powdered toothpaste causing the greatest reduction and also two of the false-negative results at two sites. BioWatch filter extracts were also analyzed at each site, including filter extracts spiked with Abrus precatorius bean extracts at approximately $10 \mu \mathrm{g} / \mathrm{mL}$. Filter extracts did not affect the performance of the assay. The LOD for this assay was estimated as $10 \mathrm{ng} / \mathrm{mL}$.

Hodge, D. R.; Prentice, K. W.; Ramage, J. G.; Prezioso, S.; Gauthier, D.; Swanson, T. ; Hastings, R.; Basavanna, U.; Datta, S.; Sharma, S. K.; Garber, E. A. E.; Staab, A.; Pettit, D.; Drumgoole, R.; Swaney, E.; Estacio, P. L.; Elder, I. A.; Kovacs, G.; Morse, B. S.; Kellogg, R. B.; Stanker, L.; Morse, S. A.; Pillai, S. P. Comprehensive Laboratory Evaluation of a Highly Specific Lateral Flow Assay for the Presumptive Identification of Ricin in Suspicious White Powders and Environmental Samples. Biosecurity and Bioterrorism: Biodefense Strategy, Practice, and Science 2013 11, 237-250. DOI: 10.1089/bsp.2013.0053.

This comprehensive study of BioThreat Alert ${ }^{\circledR}$ ricin test strips and the optical reader included evaluations of sensitivity, specificity, and reproducibility using panels of different sample types at five laboratories. Tests were conducted using $150 \mu \mathrm{L}$ of sample and read both visually and with the BioThreat Alert ${ }^{\circledR}$ Reader. A total of 129 negative controls were analyzed during the course of the study. All negative 
control results yielded negative results as expected. Repeatability studies were conducted using ricin samples prepared at 20 and $40 \mathrm{ng} / \mathrm{mL}$ (120 samples analyzed at each concentration). All 240 samples analyzed by 9 different operators at 5 different sites, tested on at least 2 different days were correctly identified as containing ricin, and the optical reader values for samples of $20 \mathrm{ng} / \mathrm{mL}(681 \pm 201)$ and 40 $\mathrm{ng} / \mathrm{mL}(1191 \pm 264)$ were significantly different. It should be noted that the optical reader values had some dependency on the time of the reading (e.g., 15 vs. 20 vs. 30 minutes), and the rate of change of optical reader value had some dependence on ricin concentration, although this has little consequence when the assay is used in a qualitative manner. With additional analysis of ricin samples for a LOD study, the sensitivity (LOD) of the assay was determined to be $3.6 \mathrm{ng} / \mathrm{mL}$. For inclusivity testing (i.e., ability to correctly detect ricin from different plant cultivars), 18 different ricin cultivars were used to prepare samples at $667 \mathrm{ng} / \mathrm{mL}$ and tested once per site. All results were positive, although the authors point out in a detailed discussion that it is not possible to determine if the positive results are due solely to the presence of ricin. A series of different forms of ricin such as $\mathrm{RCA}_{60}$ and $\mathrm{RCA}_{120}$ (i.e., an "informational panel”) was prepared at $667 \mathrm{ng} / \mathrm{mL}$ and tested once per site. As with most assays, this assay cannot discriminate among $\mathrm{RCA}_{60}, \mathrm{RCA}_{120}$, or ricin A chain. This comprehensive study includes a detailed discussion of results, most of which were as expected. A lectin panel (35 different lectins), which could cause false-positive results by interfering with the assay antibodies, was prepared at $667 \mathrm{ng} / \mathrm{mL}$ and tested once per site (175 total samples). No false positives were observed and in no instances did the lectins cause a failure of the positive control line to appear. A near-neighbor panel (to examine additional potential false positives) consisted of crude extracts prepared from the seeds or leaves of near neighbors of Ricinus communis and Abrus precatorius at $6.67 \mu \mathrm{g} / \mathrm{mL}$, and the samples were tested once per site. Not all potential near neighbors were tested because many are not commercially available and are not common to the United States. For those near neighbors tested, all sample lines resulted in a negative result and all control lines were positive. A white powder panel included 24 powders commonly encountered by first responders and the LRN, which were prepared at $10 \mathrm{mg} / \mathrm{mL}$, vortex-mixed in buffer, allowed to settle for 5 minutes, followed by analysis of the supernatant. A total of 18 of the powder suspensions produced a clear supernatant after settling, while 6 suspensions remained opaque. After the 15 minute assay development time, none of the white powders were found to interfere with the development of the positive control line, and none gave a positive result for the presence of ricin. The 24 powder suspensions were then tested at each site after spiking with castor bean extract (containing approximately $1 \%$ ricin toxin), with a final protein concentration of approximately $66.7 \mathrm{ng} / \mathrm{mL}$ per sample. All of the assays produced a positive sample result for the ricin-spiked powder suspensions and no interference occurred with the development of the positive control line, although most of the powders did give reduced readings on the optical reader. BioWatch filter extracts were also analyzed at each site, including filter extracts spiked with castor bean extracts at approximately $6.67 \mu \mathrm{g} / \mathrm{mL}$. Filter extracts did not affect the performance of the assay.

Peckham, G. D.; Hew, B. E.; Waller, D. F.; Holdaway, C.; Jen, M. Amperometric Detection of Bacillus Anthracis Spores: A Portable, Low-Cost Approach to the Elisa. Int. J. Electrochem. 2013, 2013, Article 803485. DOI: 10.1155/2013/803485. http://www.hindawi.com/journals/ijelc/2013/803485/

This investigation compared an antibody-based method using amperometric signal generation to ELISAs and LFAs for detecting Bacillus anthracis (Sterne strain) spores. Tetracore's ELISA kit assays were used. The LFDs included BADD ${ }^{\mathrm{TM}}$, Smart ${ }^{\mathrm{TM}}$-II, and BioThreat Alert ${ }^{\circledR}$. At least 15 of each LFD were tested with spore concentrations of $10^{4} \mathrm{CFU} / \mathrm{mL}$ to $5 \times 10^{6} \mathrm{CFU} / \mathrm{mL}$. All LFDs detected $5 \times 10^{6}$ $\mathrm{CFU} / \mathrm{mL}$ in greater than $>90 \%$ of trials. Performance decreased with decreasing spore concentration 
( $<80 \%$ for $10^{6} \mathrm{CFU} / \mathrm{mL}$ and $<60 \%$ for $5 \times 10^{5} \mathrm{CFU} / \mathrm{mL}$ ). Smart ${ }^{\mathrm{TM}}$-II detected samples with $10^{5} \mathrm{CFU} / \mathrm{mL}$, but only in $<40 \%$ of trials. BioThreat Alert ${ }^{\circledR}$ was reported to be the easiest to interpret with a dark, highly contrasted test line. The readout on the $\mathrm{BADD}^{\mathrm{TM}}$ was reported to be very faint, even at high spore concentrations. ELISA had $100 \%$ positive detection for all spore concentrations, though each assay takes over 6 hours to complete. Amperometry, which required just over an hour to complete, detected spores in $>90 \%$ of trials at $>10^{5} \mathrm{CFU} / \mathrm{mL}$; however, performance decreased with decreasing spore concentration (86\% for $5 \times 10^{4} \mathrm{CFU} / \mathrm{mL}$ and $47 \%$ for $10^{4} \mathrm{CFU} / \mathrm{mL}$ ).

Townsend, M. B.; MacNeil, A.; Reynolds, M. G.; Hughes, C. M.; Olson, V. A.; Damon, I. K.; Karem, K. L. Evaluation of the Tetracore Orthopox BioThreat ${ }^{\circledR}$ Antigen Detection Assay Using Laboratory Grown Orthopoxviruses and Rash Illness Clinical Specimens. J. Virol. Methods 2013, 187, 37- 42. DOI: 10.1016/j.jviromet.2012.08.023.

This study evaluated Tetracore's BioThreat ${ }^{\circledR}$ Alert assay for orthopoxvirus, which is an assay designed to detect the causative agent of smallpox. Using a $150 \mu \mathrm{L}$ sample volume, assay results were read after 15 minutes both visually and using an optical lateral flow reader from Qiagen. Cultured Congo Basin strains of Vaccinia virus and Monkeypox virus at concentrations of $10^{4}$ to $10^{8} \mathrm{PFU} / \mathrm{mL}$ were used to evaluate the sensitivity of the assay in duplicate by two different users. The BioThreat ${ }^{\circledR}$ Alert assay positively detected all samples at concentrations of $10^{7} \mathrm{PFU} / \mathrm{mL}$ for both viruses and 4 of 7 assays at $10^{6} \mathrm{PFU} / \mathrm{mL}$. When incubation time was extended up to 30 minutes, all samples at $10^{6} \mathrm{PFU} / \mathrm{mL}$ were positive and 1 sample at $10^{5} \mathrm{PFU} / \mathrm{mL}$ was positive. Specificity was assessed using 22 unique blinded clinical samples measured in duplicate (5 Vaccinia virus samples and 6 Monkeypox virus samples). The assay correctly identified 9 of 11 orthopoxvirus clinical samples, but did not detect one Vaccinia virus sample and one Monkeypox virus. One false-positive result was observed for 11 non-orthopoxvirus clinical samples.

Sha, J.; Endsley, J. J.; Kirtley, M. L.; Foltz, S. M.; Huante, M. B.; Erova, T. E.; Kozlova, E. V.; Popov, V. L.; Yeager, L. A.; Zudina, I. V.; Motin, V. L.; Peterson, J. W.; DeBord, K. L.; Chopra, A. K. Characterization of an F1 Deletion Mutant of Yersinia pestis CO92, Pathogenic Role of F1 Antigen in Bubonic and Pneumonic Plague, and Evaluation of Sensitivity and Specificity of F1 Antigen CaptureBased Dipsticks. J. Clin. Microbiol. 2011, 49, 1708-1715. DOI. 10.1128/jcm.00064-11.

Two LFAs for the detection of Yersinia pestis were compared in this evaluation. BioThreat Alert ${ }^{\circledR}$ and Smart ${ }^{\mathrm{TM}}$-II performed similarly and were able to detect $10^{5}$ to $5 \times 10^{5} \mathrm{CFU} / \mathrm{mL}$ of the bacteria and 0.5 $\mu \mathrm{g} / \mathrm{mL}$ for purified antigen (i.e., the surface protein from the bacteria) in PBS or infected whole mouse blood. The authors note that their limits of detection were not as low as some other studies, which could be related to the purity of the antigen or strains of Yersinia pestis used for the various studies.

Gessler, F.; Pagel-Wieder, S.; Avondet, M-A. Bohnel, H. Evaluation of Lateral Flow Assays for the Detection of Botulinum Neurotoxin Type A and Their Application in Laboratory Diagnosis of Botulism. Diagn. Microbiol. Infect. Dis. 2007, 57, 243-249. DOI: 10.1016/j.diagmicrobio.2006.07.017.

This study evaluated BioThreat Alert ${ }^{\circledR}$, Smart ${ }^{\mathrm{TM}}-\mathrm{II}, \mathrm{BADD}^{\mathrm{TM}}$, and RAMP ${ }^{\circledR}$ assays for their ability to detect botulinum neurotoxin in three forms: purified botulinum neurotoxin A (BoNT/A), toxin complex, and toxin in the supernantant of a Clostridium botulinum culture. Only BADD ${ }^{\mathrm{TM}}$ and RAMP ${ }^{\circledR}$ detected purified BoNT/A; LODs were $100 \mathrm{ng} / \mathrm{mL}$ for BADD ${ }^{\mathrm{TM}}$ and $50 \mathrm{ng} / \mathrm{mL}$ for RAMP ${ }^{\circledR}$. All assays detected 
the BoNT/A complex, and SMART ${ }^{\mathrm{TM}}-\mathrm{II}$ and BioThreat Alert had greater sensitivity for the BoNT/A complex $(10 \mathrm{ng} / \mathrm{mL})$ than BADD ${ }^{\mathrm{TM}}(100 \mathrm{ng} / \mathrm{mL})$ and RAMP ${ }^{\circledR}(250 \mathrm{ng} / \mathrm{mL})$. For the Clostridium botulinum culture samples, the concentration of active toxin was estimated using a mouse lethality assay. The lowest concentration of toxin in culture medium that the BioThreat Alert ${ }^{\circledR}$, Smart ${ }^{\mathrm{TM}}$-II, and BADD ${ }^{\mathrm{TM}}$ could detect was 100 Minimal mouse Lethal Doses (MLD)/mL, while RAMP ${ }^{\circledR}$ could detect only 2500 $\mathrm{MDL} / \mathrm{mL}$. BADD ${ }^{\mathrm{TM}}$ gave a false-positive result for a culture medium that did not contain Clostridium botulinum or toxin.

Tomaso, H.; Thullier, P.; Seibold, E.; Guglielmo, V.; Buckendahl, A.; Rahalison, L.; Neubauer, H.; Scholz, H. C.; Splettstoesser, W. D. Comparison of Hand-Held Test Kits, Immunofluorescence Microscopy, Enzyme-Linked Immunosorbent Assay, and Flow Cytometric Analysis for Rapid Presumptive Identification of Yersinia pestis. J. Clin. Microbiol. 2007, 45, 3404-3407. DOI: 10.1128/JCM.00458-07.

This study compared an in-house immunochromatographic test (20 minute total test time), antibodybased flow cytometry (40 minute total test time), and immunofluorescence microscopy (120 minute total test time) with Tetracore's Plague BioThreat Alert ${ }^{\circledR}$ test strips (25 minute total test time), Senova's ABICAP columns (AntiBody Immuno Column for Analytical Purpose) (65 minute total test time), and Seramun's enzyme-linked immunosorbent assay (140 minute total test time). Samples were prepared from buffer and clinical samples spiked with the fraction 1 capsular antigen of 10 different strains of Yersinia pestis. The BioThreat Alert ${ }^{\circledR}$ test strips positively detected a concentration of $7 \times 10^{3} \mathrm{CFU} / \mathrm{mL}$ in triplicate spiked buffer, but not spiked sputum (2 samples), serum (20 samples), or urine (20 samples). The immunochromatographic test positively detected all sample types at $3 \times 10^{3} \mathrm{CFU} / \mathrm{mL}$. The ABICAP test and ELISA positively detected all sample types at $6 \times 10^{3} \mathrm{CFU} / \mathrm{mL}$. The flow cytometry method and immunofluorescence microscopy did not produce any positive results at $5 \times 10^{3}$ and $10^{3} \mathrm{CFU} / \mathrm{mL}$, respectively. Exclusivity testing was performed using 34 clinically relevant bacteria at $5 \times 10^{8} \mathrm{CFU} / \mathrm{mL}$ (45 bacterial strains total). None of the assays gave false-positive results with any of the exclusivity samples.

King, D.; Luna, V.; Cannons, A.; Cattani, J.; Amuso, P. Performance Assessment of Three Commercial Assays for Direct Detection of Bacillus anthracis Spores. J. Clin. Microbiol. 2003, 41, 3454-3455. DOI:10.1128/JCM.41.7.3454-3455.2003.

This brief study by the Florida Department of Health Laboratory evaluated three immunoassay tests including BioThreat Alert ${ }^{\circledR}$, Osborne Scientific's $1^{\text {st }}$ generation BADD (Note: Osborne's biothreat product line was acquired by AdVnt in 2003 and the current assay is $3^{\text {rd }}$ generation), and Smart ${ }^{\mathrm{TM}}-\mathrm{II}$. The tests were evaluated for Bacillus anthracis (Pasteur strain) detection at concentrations ranging from $10^{2}$ to $10^{6}$ spores (the concentration of the test samples and volume of sample applied were not reported). Only 2 to 8 samples were tested at each concentration. All test kits could detect Bacillus anthracis at $10^{6}$ spores. BADD $^{\mathrm{TM}}$ and Smart ${ }^{\mathrm{TM}}$-II could detect $10^{5}$ spores; however, BioThreat Alert ${ }^{\circledR}$ detected $10^{5}$ spores only once in eight separate assays. None of the assays could detect fewer than 10,000 spores. Tests were allowed to develop for 15 minutes, although positive results were apparent within 5 minutes. Bacillus cereus and Bacillus thuringiensis (non-threat near neighbors that could potentially result in a falsepositive) were also tested twice for each test strip. No false positives were observed for the BADD ${ }^{\mathrm{TM}}$ or BioThreat Alert ${ }^{\circledR}$ tests; however, the Smart ${ }^{\mathrm{TM}}$-II tests yielded one false-positive result for Bacillus 


\subsection{PCR-Based Detection Systems}

PCR-based assays detect specific organisms based on their DNA sequence. During PCR, short pieces of DNA from the biothreat organism are amplified, creating millions of DNA copies from just a few hundred starting molecules. The assay is designed to recognize regions of DNA that are unique to the biothreat organism(s).

Most field-based PCR systems consist of a disposable assay cartridge containing all of the consumable reagents (including the required polymerase), an instrument that integrates the thermal components to perform the heat/cool cycles required for PCR, and the optical components required to quantify the amplified

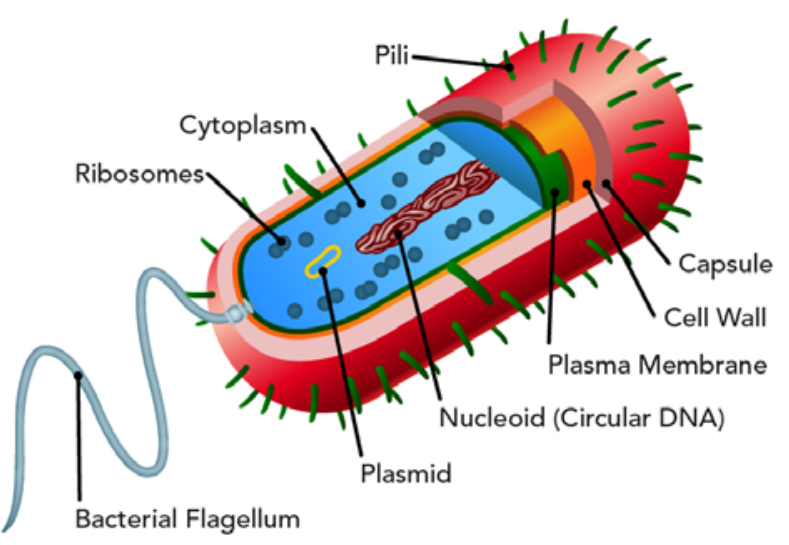

Illustration of a bacterial cell. All cells and viruses contain DNA or RNA that can be used to detect and identify them.

DNA products. PCR assays are performed on liquid samples and require a sampling kit (sometimes included) to swab a suspicious powder and solubilize or suspend the white powder in a compatible buffer. Depending on the system, various degrees of sample preparation or cartridge manipulation may be required including pipetting, manual mixing, or centrifugation. In the instrument, the sample/reagent mixture is cycled between high and low temperatures to amplify the biothreat agent DNA. Many PCR assay formats result in a final dye-labeled product DNA, which is measured by integrated optical components (usually fluorescence-based). Most assays contain an internal positive control to ensure the system components and reagent cartridges are performing as specified. Failure of an internal positive control can indicate problems with the system hardware/software, cartridge reagent issues, or presence of interfering substances in the sample.

PCR-based assays are advantageous because they are very sensitive and specific (although the specificity of a system is dependent on the design of a particular assay). Few field-based PCR systems

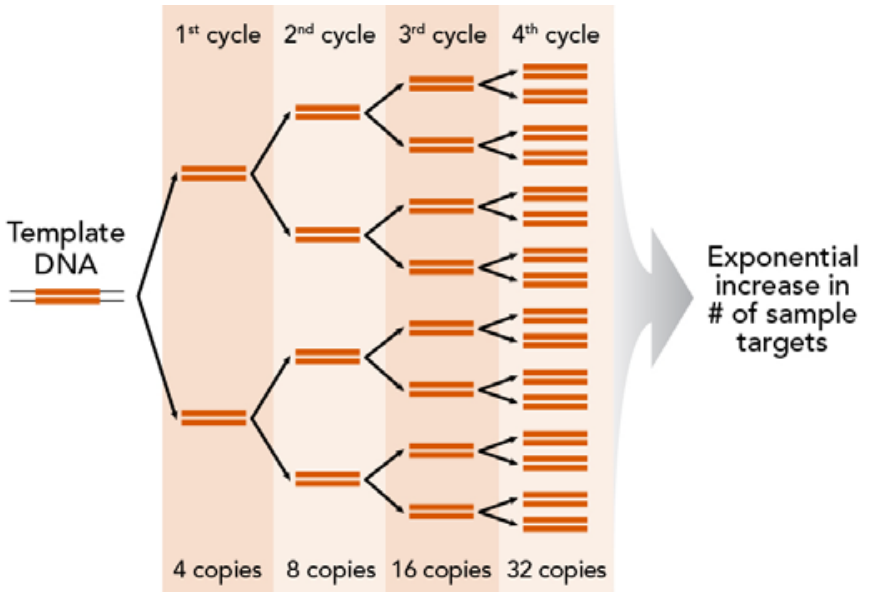

PCR can amplify a single piece of DNA ("target") to make millions of copies in 30 to 60 minutes. have integrated sample preparation to concentrate DNA and remove PCR inhibitors; however, because PCR is very sensitive, a sample can often be significantly diluted after sampling to reduce the effects of potential inhibitors on the reaction. Little published work has been done to assess the impact of environmental samples and hoax powders on PCR-based assays when little or no sample preparation is conducted. The most significant disadvantages of PCR-based approaches are relatively long assay times (typically 30 to 60 minutes) and, for some systems, relatively high costs (instruments range from $\$ 5900$ to $\$ 55,000$, and assays range from $\$ 12$ to $\$ 200$, although assays for 
individual "targets” are as low as $\$ 7$ each). Some assays detect more than one "target” (a specific region on a biothreat agent) and positive detection of multiple targets in a sample can improve confidence that the biothreat agent is actually present. PCR assays will not detect toxins, unless the toxin preparation contains DNA from the source organism (e.g., castor bean DNA in a preparation of ricin toxin).

\section{Hand-Portable PCR-based Systems}

- Assay cost: $\$ 12$ to $\$ 200$

- Instrument cost: $\$ 5900$ to $\$ 55,000$

- Examples:

- FilmArray $^{\circledR}$ (BioFire Diagnostics)

- R.A.P.I.D. ${ }^{\circledR}$ (BioFire Diagnostics)

- RAZOR $^{\circledR}$ EX (BioFire Diagnostics)

- POCKIT (Gene Reach USA)

- Bio-Seeq ${ }^{\mathrm{TM}}$ PLUS (Smiths Detection)

- T-COR 4 ${ }^{\mathrm{TM}}$ (Tetracore) 


\section{BioFire Diagnostics, Inc.: FilmArray ${ }^{\circledR}$}

Product Link: http://www.biofiredx.com/FilmArray/index-BioDef.html

Contact: Matt Scullion, Biodefense Marketing Manager (Matt.Scullion@biofiredx.com)

Phone (800) 735-6544 Manufacturer's website: http://www.biofiredx.com

\section{Technology Summary}

The FilmArray ${ }^{\circledR}$ is a fully automated multiplexed PCR-based platform. The system consists of four components: the loading station, reagent pouch, instrument/detector, and PC (see figure).

After injecting a hydration solution and the sample, all preparation, extraction, amplification, and detection steps are automated. The sample passes through a series of chambers within the reagent pouch. In the first chamber, cells/spores are lysed by mechanical agitation with ceramic beads and a lysis solution. The next set of chambers purifies and concentrates the nucleic acids using magnetic beads. In the last chamber, RNA is reverse transcribed into cDNA and the first round of multiplexed PCR amplification is performed. The sample is then diluted and partitioned into 120 separate $1 \mu \mathrm{L}$ reaction wells, each containing reagents and a targetspecific primer pair for a second stage single-plex PCR. In addition, each well contains a fluorescent probe that binds to double-stranded DNA. A patented postPCR, high-resolution melting point analysis is used to identify positive biothreat agents by monitoring the fluorescence quenching of a double-stranded DNA binding probe. The melting curve is dependent upon the length, DNA composition and degree of complementarity of the duplex DNA. Software integrates the results from replicate samples and multiple signatures to determine if a sample is reported as positive or negative.

BioFire Diagnostics (BFDx) has a biothreat panel that simultaneously tests a single sample for the presence of 27 targets (17 agents). Initial testing of the FilmArray ${ }^{\circledR}$ biothreat pouch by the Pacific Northwest National Laboratory (PNNL) (publication listed below) for detection of Bacillus anthracis, Francisella tularensis, and Yersinia pestis genomic DNA samples supports the manufacturer's sensitivity

\section{Specifications}

FilmArray ${ }^{\circledR}$ PCR Instrument and Associated Components

\begin{tabular}{|c|c|c|}
\hline \multicolumn{3}{|c|}{ Biothreat 17-Agent Assay } \\
\hline Disease/Toxin & Causative Agent/Source & LOD* \\
\hline Anthrax & Bacillus anthracis & 500 spores $/ \mathrm{mL}$ \\
\hline $\begin{array}{l}\text { Botulism } \\
\text { (botulinum toxin) }\end{array}$ & Clostridium botulinum & $1 \mu \mathrm{g} / \mathrm{mL}$ \\
\hline Brucellosis & Brucella species & $1000 \mathrm{CFU} / \mathrm{mL}$ \\
\hline $\begin{array}{l}\text { Glanders/ } \\
\text { melioidosis }\end{array}$ & $\begin{array}{l}\text { Burkholderia } \\
\text { mallei/pseudomallei }\end{array}$ & $1000 \mathrm{CFU} / \mathrm{mL}$ \\
\hline Hemorrhagic fever & Ebola virus & 10,000 PFU/mL \\
\hline Hemorrhagic fever & Marburg virus & $10,000 \mathrm{PFU} / \mathrm{mL}$ \\
\hline Plague & Yersinia pestis & $500-5000 \mathrm{GE} / \mathrm{mL}^{* *}$ \\
\hline Q fever & Coxiella burnetii & $1000 \mathrm{CFU} / \mathrm{mL}$ \\
\hline Ricin toxin & Ricinus communis & $1 \mu \mathrm{g} / \mathrm{mL}$ \\
\hline SEB & Staphylococcus aureus & $1000 \mathrm{CFU} / \mathrm{mL}$ \\
\hline Smallpox & variola virus (species) & $10,000 \mathrm{PFU} / \mathrm{mL}$ \\
\hline Smallpox & variola virus (genus) & $10,000 \mathrm{PFU} / \mathrm{mL}$ \\
\hline Tularemia & Francisella tularensis & $5000 \mathrm{GE} / \mathrm{mL}^{\star *}$ \\
\hline Typhus & Rickettsia prowazekii & $1000 \mathrm{CFU} / \mathrm{mL}$ \\
\hline Viral encephalitis & VEE virus & 10,000 PFU/mL \\
\hline Viral encephalitis & EEE virus & $10,000 \mathrm{PFU} / \mathrm{mL}$ \\
\hline Viral encephalitis & WEE virus & $10,000 \mathrm{PFU} / \mathrm{mL}$ \\
\hline \multicolumn{3}{|c|}{$\begin{array}{l}\text { *Reported by manufacturer and peer-reviewed publications. } \\
{ }_{* \star} \mathrm{GE}=\text { genome equivalent }(\mathrm{GE} / \mathrm{mL} \sim \mathrm{CFU} / \mathrm{mL})\end{array}$} \\
\hline \\
\hline \multicolumn{3}{|c|}{ Required sample preparation? Minimal. } \\
\hline \multicolumn{3}{|c|}{ Automatic results display? Yes. } \\
\hline \multicolumn{3}{|c|}{ Unit weight: $20 \mathrm{lb}}$. \\
\hline \multicolumn{3}{|l|}{ Power: $110 \mathrm{~V}$ AC. } \\
\hline \multicolumn{3}{|c|}{$\begin{array}{l}\text { Cost: Assay - } \$ 1080 / 6 \text { pack }(\$ 180 \text { ea, } \$ 10.59 / \text { agent, } \\
\quad \$ 6.67 / \text { target); instrument - } \$ 49,500 \text {. }\end{array}$} \\
\hline \multicolumn{3}{|c|}{ Additional costs: Sample collection supplies. } \\
\hline \multicolumn{3}{|c|}{ Assay shelf-life: 6 months from date of manufacture. } \\
\hline
\end{tabular}


claims. In addition, an FDA-approved respiratory panel is commercially available. While numerous peerreviewed publications exist for the respiratory panel, they are not listed below.

The management system governing the manufacture of this product is ISO 9001:2008-certified (specifies the requirements of a quality management system) and ISO 13485:2003-certified (specifies the requirements of a quality management system for medical devices).

\section{Peer-Reviewed References}

Seiner, D. R.; Colburn, H. A.; Baird, C.; Bartholomew, R. A.; Straub, T.; Victry, K.; Hutchison, J. R.; Valentine, N.; Bruckner-Lea, C. J. Evaluation of the FilmArray ${ }^{\circledR}$ System for Detection of Bacillus anthracis, Francisella tularensis, and Yersinia pestis. J. Appl. Microbiol. 2013, 114, 992-1000. DOI: 10.1111/jam.12107.

This study evaluated the sensitivity and specificity of the BioFire Diagnostics FilmArray ${ }^{\circledR}$ system using the Biothreat pouch for the detection of three strains each of Bacillus anthracis, Francisella tularensis, and Yersinia pestis DNA and a brief evaluation of ability to detect Bacillus anthracis spores (Sterne strain). The FilmArray® software algorithm requires the positive detection of all included targets for Bacillus anthracis and one target for Francisella tularensis or Yersinia pestis before a positive identification of the biothreat agent is indicated. The Biothreat pouch includes three targets for Bacillus anthracis (pX01, pX02, and a chromosomal target) and two targets each for Francisella tularensis (FTT2 and FTT3 targets) and Yersinia pestis (YpT1 and YpT3 targets). Results indicate that the sensitivity for these assays is approximately 5000 genome equivalents (GE) per $\mathrm{mL}$ or lower. At concentrations of 5000$500,000 \mathrm{GE} / \mathrm{mL}$, positive identification occurred in 53 of 54 samples tested with 1 false-negative occurring for Francisella tularensis strain holarctica 425 at a concentration of $5000 \mathrm{GE} / \mathrm{mL}$. For concentrations of 250 to $500 \mathrm{GE} / \mathrm{mL}, 23$ of 24 samples were correctly identified as Bacillus species, but Bacillus anthracis was not indicated because not all targets were detected. For Francisella tularensis and Yersinia pestis, positive results were obtained in 40 of 48 samples. To assess the potential for falsepositive results, DNA from three near-neighbor organisms was tested (three strains for Bacillus anthracis and Francisella tularensis and four strains for Yersinia pestis) at concentrations ranging from $5 \times 10^{4}$ to $5 \times 10^{6} \mathrm{GE} / \mathrm{mL}$. No false-positive results were obtained for any near neighbors in the 60 exclusivity samples that were tested. However, near-neighbor strains having a particular biothreat target (e.g., pX01) did produce a positive result for that target (but did not generate a positive detection result for a biothreat agent). While no false-positive biothreat agents were observed (which requires the positive detection of all targets for that particular biothreat), four false-positive detections occurred for a Bacillus anthracis target when testing Yersinia species-containing samples (either inclusivity or near-neighbor/exclusivity samples). One Francisella tularensis sample $(500,000 \mathrm{GE} / \mathrm{mL})$ generated a false-positive result, indicating the presence of Staphylococcus aureus (i.e., the presence of two biothreats was indicated rather than just the actual Francisella tularensis present). Of the 38 blank samples analyzed, only one falsepositive detection resulted, which was likely due to a pouch failure. Of 226 assays performed, two software crashes of unknown cause resulted in failures of those assays, requiring re-analysis of the samples. Inspection of the raw data indicated that the false-positive was due to the incorrect software interpretation of a melt curve, as no amplification was observed in the saved data. Six replicate samples containing 500 spores/mL of Bacillus anthracis (Sterne strain), which only contains the pX01 and chromosomal targets, but not the pX02 target, were also analyzed. One of the two targets was detected in all samples and both the targets were detected in three samples. 
BioFire Diagnostics, Inc.: R.A.P.I.D. ${ }^{\circledR}$

Product Link: http://www.biofiredx.com/RAPID/index.html

Contact: Matt Scullion, Biodefense Marketing Manager (Matt.Scullion@biofiredx.com

Phone: (800) 735-6544 Manufacturer's website: http://www.biofiredx.com

\section{Technology Summary}

The Ruggedized Advanced Pathogen Identification Device (R.A.P.I.D. ${ }^{\circledR}$ ) is a portable real-time PCR system. A military version of this system (Joint Biological Agent Identification and Diagnostic System [JBAIDS]) is available exclusively to the DoD R.A.P.I.D. ${ }^{\circledR}$ integrates BFDx LightCycler ${ }^{\circledR}$ instrument technology into a rugged, portable enclosure that fits in a backpack. A PC and sample preparation materials (e.g., vortexer, microfuge, pipettes, racks, and wipes) are also included in the backpack. The system requires a 110 or $220 \mathrm{~V}$ power source for operation.

The system is highly configurable-it can use stock assays and reagents developed by BFDx or other party realtime PCR assays selected by the user. In addition, it is possible to multiplex up to four signatures in one reaction. Up to 32 samples, which includes positive and negative control samples, can be analyzed in parallel in $<30$ minutes, not including sample preparation. Sample preparation is performed offline and can take up to an additional 1.5 hours.

\begin{tabular}{l}
\hline \multicolumn{2}{|c|}{ Specifications } \\
\hline
\end{tabular}

Some of the assays listed in the specifications table are offered for multiple targets to improve detection confidence. Assays are also offered for the detection of bacteria (Listeria monocytogenes, Campylobacter species, Salmonella species, and E. coli 0157), protozoa (Cryptosporidium), and avian influenza; and there is also an assay for in-vitro diagnostic anthrax detection.

The management system governing the manufacture of this product is ISO 9001:2008-certified (specifies the requirements of a quality management system) and ISO 13485:2003-certified (specifies the requirements of a quality management system for medical devices).

\section{Peer-Reviewed References}

No peer-reviewed publications were found that demonstrate the use of this product for the detection of biothreat agents. 


\section{BioFire Diagnostics, Inc.: RAZOR ${ }^{\circledR}$ EX}

Product Link: http://www.biofiredx.com/RAZOREX/index.html

Contact: Matt Scullion, Biodefense Marketing Manager (Matt.Scullion@biofiredx.com)

Phone: (800) 735-6544 Manufacturer's website: http://www.biofiredx.com

\section{Technology Summary}

The RAZOR $^{\circledR}$ EX is a PCR-based system for pathogen detection in the field. The RAZOR ${ }^{\circledR}$ EX system is packaged in an over-the-shoulder carrying case weighing 11 lb. The system includes a rechargeable internal battery pack that can power the system for eight assays. The system has been extensively tested for field use (e.g., temperature, humidity, vibration, and drop tests); and it is currently being used by a wide range of first responders (e.g., police and fire departments).

The system performs PCR on a crude sample solubilized from a swab. Typically, a single sample is injected into the "reagent pouch," which contains all of the assay reagents (e.g., primers, probes, enzymes, and buffers) needed for the PCR reaction. The system performs minimal sample preparation in the form of sample dilution to reduce the effects of possible PCR inhibitors and uses thermal disruption to release DNA from cells and viruses. No additional cleanup of the sample is performed. In preparing the pouch for a run, there are several required manual preparation steps that involve fine manual dexterity. Within the pouch, the sample is split among 12 channels for 12 independent PCR assays. For the BioThreat 10 panel, 10 of the channels are used for pathogen detection (1 signature per channel), and the remaining 2 channels used for control reactions to measure the effect of inhibitors that may be present in a sample. If the sample contains PCR inhibitors, the user is directed to dilute the sample and re-run the assay. Each instrument run takes approximately 30 minutes. A Food Screen 3-Agent Assay

\begin{tabular}{|c|c|c|}
\hline \multicolumn{3}{|c|}{ Specifications } \\
\hline $\begin{array}{r}R \\
\text { Reage }\end{array}$ & $\begin{array}{l}\text { AZOR }{ }^{\circledR} \text { EX PCR Instru } \\
\text { nt Pouch, Buffer, and }\end{array}$ & $\begin{array}{l}\text { Sent, } \\
\text { Syringes }\end{array}$ \\
\hline \multicolumn{3}{|c|}{ Biothreat 10-Agent and 1-Agent Assays } \\
\hline Disease/Toxin & $\begin{array}{c}\text { Causative } \\
\text { Agent/Source }\end{array}$ & LOD* \\
\hline \multicolumn{3}{|c|}{ Available RAZOR ${ }^{B}$ 10-Agent Biothreat Assay } \\
\hline Anthrax & Bacillus anthracis & $10^{3} \mathrm{CFU} / \mathrm{mL}$ \\
\hline Brucellosis & Brucella species & $3 \times 10^{4} \mathrm{CFU} / \mathrm{mL}$ \\
\hline Bacterial infection & E. coli 0157 & $3 \times 10^{3} \mathrm{CFU} / \mathrm{mL}$ \\
\hline Bacterial infection & Salmonella & $3.5 \times 10^{2} \mathrm{CFU} / \mathrm{mL}$ \\
\hline $\begin{array}{l}\text { Botulism } \\
\text { (botulinum toxin) }\end{array}$ & Clostridium botulinum & $3 \times 10^{3} \mathrm{CFU} / \mathrm{mL}$ \\
\hline Plague & Yersinia pestis & $10^{2} \mathrm{CFU} / \mathrm{mL}$ \\
\hline Q fever & Coxiella & $10^{3} \mathrm{CFU} / \mathrm{mL}$ \\
\hline Ricin toxin & Ricinus communis & $1 \mu \mathrm{g} / \mathrm{mL}$ \\
\hline Smallpox & variola virus & 238 DNA copies \\
\hline Tularemia & Francisella tularensis & $10^{2} \mathrm{CFU} / \mathrm{mL}$ \\
\hline \multicolumn{3}{|c|}{ Available RAZOR ${ }^{(B)}$ 1-Agent (3 Target) Biothreat Assay } \\
\hline Anthrax & $\begin{array}{l}\text { Bacillus anthracis, } p X \\
\text { target } 1\end{array}$ & \begin{tabular}{l|l}
1 & $10^{3} \mathrm{CFU} / \mathrm{mL}$
\end{tabular} \\
\hline Anthrax & $\begin{array}{l}\text { Bacillus anthracis, } p X \\
\text { target } 2\end{array}$ & \begin{tabular}{l|l}
$10^{3} \mathrm{CFU} / \mathrm{mL}$ \\
\end{tabular} \\
\hline Anthrax & $\begin{array}{l}\text { Bacillus anthracis, } p X \\
\text { target }\end{array}$ & \begin{tabular}{l|l}
2 & $10^{3} \mathrm{CFU} / \mathrm{mL}$
\end{tabular} \\
\hline \multicolumn{3}{|c|}{ *Reported by manufacturer and peer-reviewed publication. } \\
\hline \multicolumn{3}{|c|}{$\begin{array}{l}\text { Assay time: } 30 \text { minutes. } \\
\text { Required sample preparation? Minimal. } \\
\text { Automatic results display? Yes. } \\
\text { Unit weight: } 11 \mathrm{lb} \text {. } \\
\text { Power: Battery (8 runs/charge). } \\
\text { Cost: Assay - } \$ 200 / 10 \text {-agent assay (\$20/agent), } \$ 180 \text { for } 1 \text { - } \\
\text { agent/3 target assay (\$60/target); instrument - } \$ 38,500 \text {. } \\
\text { Additional costs: Sample collection supplies. } \\
\text { Assay shelf-life: } 6 \text { months from date of manufacture. }\end{array}$} \\
\hline
\end{tabular}


is available (Campylobacter, Listeria monocytogenes and Salmonella); and a Water Screen 3-Agent Assay (Cryptosporidium, E. coli 0157 and Salmonella) is also available.

Biothreat assays have been evaluated by end-users in various countries (testing sponsored by BFDx and reported on the BFDx website). The BioThreat 10 target screen kit tests for Bacillus anthracis, Brucella, Coxiella, E. coli, Francisella tularensis, Salmonella, Yersinia pestis, smallpox, ricin toxin, and botulinum toxin. In addition, the $\mathrm{RAZOR}^{\circledR}$ platform has been independently evaluated in a DHSsponsored Stakeholder Panel on Agent Detection Assays (SPADA) (see AOAC reference below) for the analysis of extracts from aerosol collection filters and with manual sample preparation done prior to PCR analysis. This extensive testing found that 2473 of the 2479 samples tested provided the expected results (99\% success with 95\% confidence). Unfortunately, the anthrax assay evaluated in these studies is not commercially available, so the applicability of these results to the currently distributed assay is unknown.

The management system governing the manufacture of this product is ISO 9001:2008-certified (specifies the requirements of a quality management system) and ISO 13485:2003-certified (specifies the requirements of a quality management system for medical devices).

\section{Peer-Reviewed References}

Hadfield, T.; Ryan, V.; Spaulding, U. K.; Clemens, K. M.; Ota, I. M.; Brunelle, S. L. Razor Ex Anthrax Air Detection System for Detection of Bacillus Anthracis Spores from Aerosol Collection Samples: Collaborative Study. J. AOAC Int. 2013, 96, 392-398. DOI: 10.5740/jaoacint.CS2012-06.

This report summarizes the results of a collaborative study that tested the RAZOR EX at 3 sites by 12 operators for the ability to measure Bacillus anthracis in simulated aerosol collection buffer. The RAZOR assay pouch used in this study is no longer commercially available. The pouch detected three targets of Bacillus anthracis (pX01, pX02, and a chromosomal target). Samples were prepared using $1 \mathrm{mg} / \mathrm{mL}$ of standardized dust in PBS and spiked with either 2000 spores/mL of Bacillus anthracis Ames strain (expected positive result) or 20,000 spores/mL of Bacillus cereus, a near-neighbor expected to yield a negative result. Because this study was evaluating the RAZOR EX as a tool for the laboratory analysis of aerosol filters, significant sample preparation was done prior to detection. This complex level of sample preparation would likely not be performed by first responders analyzing suspicious powders in the field (typically only powder dilution is performed in the field). Prior to analysis on the RAZOR EX, all samples were processed as follows: 1) each sample was pipetted into a tube containing disruptor beads and placed in a vibrating Disruptor Genie ${ }^{\circledR}$ for five minutes to lyse the spores; 2) the sample was then pipetted into a tube containing magnetic beads and pipette mixed to bind the DNA in the sample onto the magnetic beads; 3) a magnet tool was used to capture the magnetic bead-DNA complex by mixing for 30 to 45 seconds; 4) the complex was transferred to a sample well containing wash solution and the process was repeated twice, each time transferring the bead-DNA complex to a new sample well; 5) the beadDNA complex was transferred to a well containing elution buffer and allowed to incubate at room temperature for at least 2 minutes to dissociate the DNA from the magnetic beads; 6 ) the magnetic beads were captured from the elution buffer using the magnet tool and discarded, leaving just DNA in the elution buffer; 7) the elution buffer sample was transferred to the RAZOR sample buffer bottle. A total of 144 samples were analyzed. Each operator analyzed 12 Bacillus anthracis Ames strain samples (144 samples total) and 12 Bacillus cereus samples (143 samples total). All 144 Bacillus anthracis Ames strain samples were positive for all three targets, and all 143 Bacillus cereus near-neighbor samples produced negative results, as expected. The performance met the requirements of AOAC Standard Method Performance Requirement 2010.003, developed by the Stakeholder Panel on Agent Detection Assays. 
Spaulding, U. K.; Christensen, C. J.; Crisp, R. J.; Vaughn, M. B.; Trauscht, R. C.; Gardner, J. R.; Thatcher, S. A.; Clemens, K. M.; Teng, D. H. F.; Bird, A.; Ota, I. M. RAZOR ${ }^{\circledR}$ EX Anthrax Air Detection System. J. AOAC Int. 2012, 95, 860-891. DOI: 10.5740/jaoacint.11-521.

This reference summarizes the AOAC Method Developer (MD) and independent laboratory validation (ILV) studies for the RAZOR ${ }^{\circledR}$ EX Anthrax Air Detection System. The RAZOR ${ }^{\circledR}$ EX pouch that was used in this study is no longer commercially available. The pouch detected three targets of Bacillus anthracis (pX01, pX02, and a chromosomal target). Because this study was evaluating the RAZOR $^{\circledR}$ EX as a tool for laboratory analysis of aerosol filters, significant sample preparation was done prior to detection. This complex level of sample preparation would not be performed by first responders analyzing suspicious powders in the field (typically only powder dilution is performed in the field). Prior to analysis on the RAZOR ${ }^{\circledR}$ EX, all samples were processed as follows: 1 ) each sample was pipetted into a tube containing disruptor beads and placed in a vibrating Disruptor Genie ${ }^{\circledR}$ for five minutes to lyse the spores; 2) the sample was then pipetted into a tube containing magnetic beads and pipette mixed to bind the DNA in the sample onto the magnetic beads; 3) a magnet tool was used to capture the magnetic beadDNA complex by mixing for 30 to 45 seconds; 4) the complex was transferred to a sample well containing wash solution and the process was repeated twice, each time transferring the bead-DNA complex to a new sample well; 5) the bead-DNA complex was transferred to a well containing elution buffer and allowed to incubate at room temperature for at least 2 minutes to dissociate the DNA from the magnetic beads; 6) the magnetic beads were captured from the elution buffer using the magnet tool and discarded, leaving just DNA in the elution buffer; 7) the elution buffer sample was transferred to the RAZOR $^{\circledR}$ sample buffer bottle. The MD studies included inclusivity/exclusivity testing using 15 strains of Bacillus anthracis and 20 strains of closely related (near-neighbor) DNA at $2000 \mathrm{GE} / \mathrm{mL}$ (equivalent to approximately 2000 spores per $\mathrm{mL}$ ) and 20,000 GE/mL respectively. All inclusivity and exclusivity strains gave expected results. Liquid and air collection filters were used as matrices with and without added standardized dust and spiked with 2000 spores $/ \mathrm{mL}$ of Bacillus anthracis Ames strain spores (inclusivity) or 20,000 spores/mL Bacillus cereus (near-neighbor) for matrix studies. A total of 96 replicates of each sample type were analyzed (768 samples total). The pX01 target test gave expected results for all replicates of each organism in all matrices. The pX02 target test yielded expected results for all but one replicate of Bacillus cereus strain E33L in a dust/filter matrix. The chromosomal target test gave expected results for all but two samples and matrices. Two clean filter samples containing Bacillus anthracis produced false-negative results, thus failing the SPADA acceptance criteria of no more than one unexpected result in 96 replicates. Environmental interference was assessed using five soil types (0.1 $\mathrm{g} / \mathrm{mL}$ with filter present; $7 \mathrm{mg} / \mathrm{mL}$ for PBS) and 23 powders/chemicals $(0.1 \mathrm{mg} / \mathrm{mL}$ with filter present; 7 $\mu \mathrm{g} / \mathrm{mL}$ for PBS) with 2000 spores/mL of Bacillus anthracis and 20,000 spores/mL of Bacillus cereus. No false-positive or false-negative results were observed for any samples. Upper and lower limits of detection were determined using DNA to be $10 \mathrm{ng} / \mathrm{test}$ volume and $50 \mathrm{fg} /$ test volume, respectively. Robustness was evaluated by deliberately varying storage time of lysed samples ( 0 and 2 hours), storage time of purified samples prior to loading into pouch ( 0 and 4 hours), storage time of pouches prior to loading samples ( 0 and 30 minutes) and storage time of loaded pouches prior to PCR analysis ( 0 and 30 minutes). None of these variations resulted in a failure to detect the presence of Bacillus anthracis for any sample. Product consistency and reliability were evaluated by testing different manufacturing lots, and over the time period of the consumable products' (DNA extraction kit and pouch) shelf-lives. No significant impact was found for these variables. Instrument variability was examined by testing six different RAZOR ${ }^{\circledR}$ EX instruments and found to be acceptable. The following ILV studies were also 
conducted. Inclusivity/exclusivity and matrix study testing was done as in the MD studies with no unexpected results, except that the pX01 target was only detected in 93 of 96 replicates in the clean filter matrix, thus failing the SPADA acceptance criteria of no more than one unexpected result in 96 replicates. However, it is important to note that the instrument did meet SPADA acceptance criteria for all of the dirty filter samples, as well as the inclusivity and exclusivity sample testing. One explanation for the poorer performance on clean filters is that DNA recovery from clean filters is lower because the biological material adheres to the clean filters. In addition, clean filters likely represent an unrealistic field situation. An ILV environmental interference study was also conducted in the same fashion as the MD study. All samples yielded expected results except that one subsoil interfered with the detection of pX01. ILV LOD studies achieved reliable detection from $1 \mathrm{pg} /$ test volume to $10 \mathrm{ng} /$ test volume. Overall, the RAZOR $^{\circledR}$ EX Anthrax Air Detection System was recommended for Performance Tested Method certification and submission for Official Method of Analysis collaborative study. 


\section{Smiths Detection, Inc.: Bio-Seeq ${ }^{\mathrm{TM}}$ PLUS}

Product Link: http://www.smithsdetection.com/biological-agents-detection/114-biological-agents-detection/bio-seeq-plus.html Contact: Ken Klein, Bio-ID Product Manager (ken.klein@smithsdetection.com)

Phone: (203) 207-9700 Manufacturer's website: http://www.smithsdetection.com

\section{Technology Summary}

The Bio-Seeq ${ }^{\mathrm{TM}}$ PLUS is a hand-portable PCR instrument that includes a battery for operation in the field. The Bio-Seeq ${ }^{\mathrm{TM}}$ PLUS uses cartridges that contain a single target assay and a control assay. Six assay cartridges can be run simultaneously on the instrument. The system relies on thermal stress to disrupt cells/spores during the assay; no specific lysis or DNA sample preparation is performed.

After sampling a white powder, a fixed pipettor (provided) is used to pipette $40 \mu \mathrm{L}$ of sample into the bottom half of a thimble-sized cartridge. The top half of the cartridge is then screwed on the bottom half, and the cartridge is shaken to mix the reagents. The cartridge is then flicked with a snapping wrist motion to move the solution down into the attached cuvette. The cartridge is placed into one of the six ports of the instrument and a run is initiated. Test results are reported as positive, negative, or indeterminate (an indeterminate result requires re-reading of the fluorescence signal).

The management system governing the manufacture of this product is ISO 9001:2008-certified (specifies the requirements of a quality management system).

\section{Peer-Reviewed References}

Emanuel, P. A.; Bell, R.; Dang, J. L.; McClanahan, R.; David, J. C.; Burgess, R. J.; Thompson, J.; Collins, L.; Hadfield, T. Detection of Francisella tularensis within Infected Mouse Tissues by Using a Hand-Held PCR Thermocycler. J. Clin. Microbiol. 2003, 41, 689-693. DOI: 10.1128/JCM.41.2.689-693.2003.

This reference describes the detection of Francisella tularensis DNA using the original BioSeeq ${ }^{\mathrm{TM}}$ instrument (a precursor to the Bio-Seeq ${ }^{\mathrm{TM}}$ PLUS). Two new TaqMan PCR assays for two different Francisella tularensis gene targets (tul4 and fopA) were developed and evaluated using the BioSeeq thermal cycler and a standard laboratory thermal cycler (ABI7900). The assays were qualified using purified Francisella tularensis genomic DNA on a standard laboratory PCR system (ABI 7900) and the

\section{Specifications}

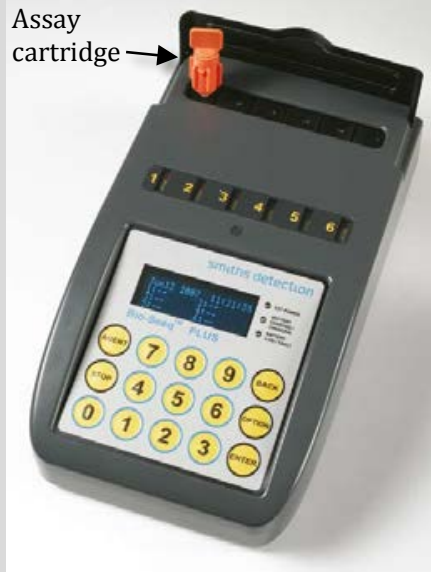

Bio-Seeq ${ }^{\mathrm{TM}}$ PLUS PCR Instrument Shown With Disposable Assay Cartridge

\begin{tabular}{|c|c|c|}
\hline \multicolumn{3}{|c|}{ Biothreat 1-Agent Assays } \\
\hline $\begin{array}{c}\text { Diseasel } \\
\text { Toxin }\end{array}$ & $\begin{array}{c}\text { Causative } \\
\text { Agent/Source }\end{array}$ & LOD* \\
\hline Anthrax & $\begin{array}{l}\text { Bacillus anthracis } \\
\text { pX01 target }\end{array}$ & $\begin{array}{l}3000-4000 \\
\text { CFU/mL }\end{array}$ \\
\hline Anthrax & $\begin{array}{l}\text { Bacillus anthracis } \\
\text { pX02 target }\end{array}$ & $\begin{array}{l}3000-4000 \\
\text { CFU/mL }\end{array}$ \\
\hline Plague & Yersinia pestis & Not reported \\
\hline Smallpox & variola virus & Not reported \\
\hline Tularemia & \begin{tabular}{|l|} 
Francisella \\
tularensis
\end{tabular} & $\begin{array}{l}100-150 \\
\text { CFU/mL }\end{array}$ \\
\hline
\end{tabular}

${ }^{\star}$ Reported by manufacturer and peer-reviewed publication.

Assay time: 60 minutes.

Required sample preparation? Minimal

Automatic results display? Yes.

Unit weight: $6.6 \mathrm{lb}$.

Power: Battery (60 runs/charge).

Cost: Assay - \$290/10 pack (\$29 ea);

instrument - $\$ 35,000$.

Additional costs: Sample collection supplies.

Assay shelf-life: 18 months from date of manufacture. 
Bio-Seeq ${ }^{\text {TM }}$ platform. The LOD was 50 fg DNA ( 25 GE of Francisella tularensis) on the ABI 7900 platform and 200-300 fg on the Bio-Seeq ${ }^{\mathrm{TM}}$ system. The utility of the assays for diagnostic purposes was evaluated using mice challenged with live Francisella tularensis. Fifty mice were divided equally into two groups-a challenge group (exposed to 312 CFU of Francisella tularensis) and a control group (not exposed). Control and challenge mice were euthanized in groups of 5 at 5 time points (1, 24, 48, 72, and 96 hours). Tissues from the liver, lungs, spleen and kidney were evaluated by culture and PCR. DNA was extracted from the mouse tissues using an automated Roche MagNA Pure LC instrument and DNA isolation Kit I reagents. Both PCR systems were able to detect Francisella tularensis DNA in all the tissues tested; however the sensitivity was reduced (i.e., tissue samples containing at least 25 CFU Francicella tularensis did not test positive) compared to the LODs reported for purified genomic DNA samples from Francisella tularensis cultures. The authors conclude the reduction in sensitivity was due to the inefficiency of the DNA extraction system with tissue samples. 
Tetracore, Inc.: T-COR $4^{\mathrm{TM}}$

Product Link: http://www.tetracore.com/t-cor/index.html

Contact: Ashley Bottomly (abottomly@tetracore.com)

Phone: (240) 268-5400 Manufacturer's website: http://www.tetracore.com

\section{Technology Summary}

The Tetracore T-COR $4^{\mathrm{TM}}$ is a handportable, battery-powered, PCR instrument. The system is capable of running four independent samples simultaneously. Two detection channels are available for each assay. Typically one target and one internal positive control assay are used in each assay tube. The instrument kit includes a carrying case and a small, battery-operated centrifuge.

After sampling and solubilizing a suspicious powder with a sampling kit (not provided), $30 \mu \mathrm{L}$ of sample is transferred into the assay tube. The assay tube is briefly centrifuged to remove bubbles and the tube is then pinched between the thumb and forefingers 8 to 10 times to ensure proper mixing. Finally, the tube is placed into the instrument and the run is initiated.

\section{Peer-Reviewed References}

No peer-reviewed publications were found that demonstrate the use of this product for the detection of biothreat agents.

\begin{tabular}{|c|c|c|}
\hline \multicolumn{3}{|c|}{ Specifications } \\
\hline $\begin{array}{l}T-C \\
\text { Batte }\end{array}$ & $\begin{array}{l}\text { OR } 4^{\mathrm{TM}} P C R \text { Instrument and } \\
\text { ry-Powered Mini-Centrifuge }\end{array}$ & \\
\hline \multicolumn{3}{|c|}{ Biothreat 1-Agent Assays } \\
\hline Disease/Toxin & Causative Agent/Source & LOD* \\
\hline Abrin & Abrin & Not reported \\
\hline Anthrax & Bacillus anthracis $\mathrm{pX} 01$ target & Not reported \\
\hline Anthrax & Bacillus anthracis $\mathrm{pX} 02$ target & Not reported \\
\hline $\begin{array}{l}\text { Botulism (botulinum } \\
\text { toxin) }\end{array}$ & Clostridium botulinum & Not reported \\
\hline Brucellosis & Brucella species & Not reported \\
\hline Melioidosis & Burkholderia & Not reported \\
\hline Plague & Yersinia pestis & Not reported \\
\hline Ricin toxin & Ricinus communis & Not reported \\
\hline Smallpox & variola virus & Not reported \\
\hline Sheep/goat pox & Capripox & Not reported \\
\hline Sheep/goat virus & Peste des Petits Ruminants & Not reported \\
\hline SEB & Staphylococcus aureus & Not reported \\
\hline Swine Fever & Classical swine fever virus & Not reported \\
\hline Tularemia & Francisella tularensis & Not reported \\
\hline Viral & African Swine Fever Virus & Not reported \\
\hline Viral & Foot and Mouth Disease Virus & Not reported \\
\hline Viral & Rinderpest & Not reported \\
\hline Viral encephalitis & Japanese Encephalitis Virus & Not reported \\
\hline \begin{tabular}{|l} 
Viral encephalitis \\
\end{tabular} & VEE & Not reported \\
\hline \multicolumn{3}{|c|}{${ }^{\star}$ Reported by manufacturer. } \\
\hline $\begin{array}{l}\text { Assay time: } 45 \mathrm{mi} \\
\text { Required sample } \\
\text { Automatic results } \\
\text { Unit weight: } 10 \mathrm{lb} \text {. } \\
\text { Power: Battery }(40 \\
\text { Cost: Assay - } \$ 76 \\
\$ 16,000 . \\
\text { Additional costs: } \\
\text { Assay shelf-life: } 1\end{array}$ & $\begin{array}{l}\text { nutes. } \\
\text { preparation? Minimal. } \\
\text { display? Yes. } \\
\text { runs/charge). } \\
8 / 64 \text { pack ( } \$ 12.00 \text { ea); instrum } \\
\text { None. } \\
2 \text { months from date of manufac }\end{array}$ & $\begin{array}{l}\text { ent - } \\
\text { cture. }\end{array}$ \\
\hline
\end{tabular}

